\title{
Republic of Belarus: Request for Stand-By Arrangement-Staff Report; Staff Supplement and Statement; Press Release on the Executive Board Discussion; and Statement by the Executive Director for the Republic of Belarus.
}

In the context of the Republic of Belarus's request for a stand-by arrangement, the following documents have been released and are included in this package:

- $\quad$ The staff report for the Request for Stand-By Arrangement, prepared by a staff team of the IMF, following discussions that ended on December 20, 2008, with the officials of the Republic of Belarus on economic developments and policies. Based on information available at the time of these discussions, the staff report was completed on January 5, 2009. The views expressed in the staff report are those of the staff team and do not necessarily reflect the views of the Executive Board of the IMF.

- A staff supplement of January 8, 2009, on the assessment of the risks to the Fund and the Fund's liquidity position.

- A staff statement of January 12, 2009, updating information on recent developments.

- $\quad$ A Press Release summarizing the views of the Executive Board as expressed during its January 12, 2009 discussion of the staff report that completed the request.

- A statement by the Executive Director for the Republic of Belarus.

The documents listed below have been or will be separately released.

Letter of Intent sent to the IMF by the authorities of the Republic of Belarus*

Memorandum of Economic and Financial Policies by the authorities of the Republic of Belarus*

Technical Memorandum of Understanding*

*Also included in Staff Report

The policy of publication of staff reports and other documents allows for the deletion of market-sensitive information.

\author{
Copies of this report are available to the public from \\ International Monetary Fund $\bullet$ Publication Services \\ $70019^{\text {th }}$ Street, N.W. • Washington, D.C. 20431 \\ Telephone: (202) 623-7430 • Telefax: (202) 623-7201 \\ E-mail: publications@imf.org Internet: http://www.imf.org
}

\section{International Monetary Fund Washington, D.C.}





\section{INTERNATIONAL MONETARY FUND}

\section{REPUBLIC OF BELARUS}

\section{Request for Stand-By Arrangement}

Prepared by the European Department in Consultation with Other Departments

Approved by Juha Kähkönen and Thanos Arvanitis

January 5, 2009

- Stand-By Arrangement. In the attached letter, the Belarusian authorities are requesting a 15-month $\$ 2.5$ billion (SDR 1.618118 billion) Stand-By Arrangement involving exceptional access (418.77 percent of quota, Appendix I). An initial purchase of SDR 517.798 million becomes available upon Board approval of the arrangement, with the remainder phased thereafter, subject to quarterly reviews. In the letter the authorities outline the economic program for which they seek Fund financial support and describe its economic policy objectives. The two key objectives are (i) to facilitate an orderly adjustment to external shocks faced; and (ii) to address pressing vulnerabilities. The authorities' plan incorporates exchange rate policy shifts, fiscal and incomes policy adjustments, and transformation and modernization of the state banking sector.

- Discussions. Between October 27-December 20, 2008, over two missions, the staff team met with the Deputy Prime Minister Mr. Kobiakov, the Governor of the National Bank of the Republic of Belarus, Mr. Prokopovich; the Minister of Finance, Mr. Kharkovec; the Minister of Economy, Mr. Zaichenko; and other senior officials.

- Staff. The staff team participating in one or both of the missions comprised Mr. Kähkönen (head, November 8-20); Mr. Mates (head, October 27-November 7 and December 15-21); Messrs. Flanagan and Tiffin, and Mmes. Banerji and Hassine (EUR); Mr. Wane (FAD); Mr. Prokopenko (MCM); and Messrs. Kovtun and Mukhopadhyay (SPR).

- Publication. In accordance with policy on exceptional access, the staff report will be published. The authorities have also consented to publish the accompanying Financial Sector Stability Assessment, completed as part of the 2008 FSAP Update. 
Contents

I. Introduction

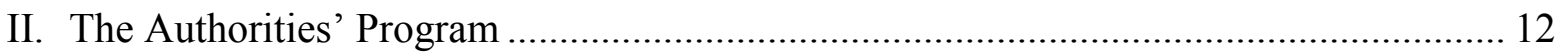

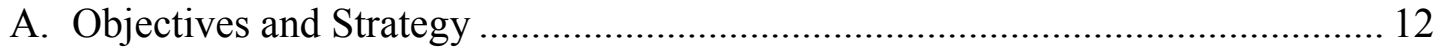

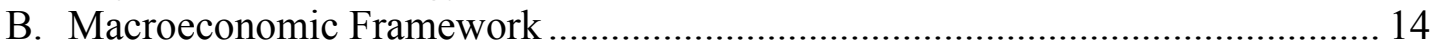

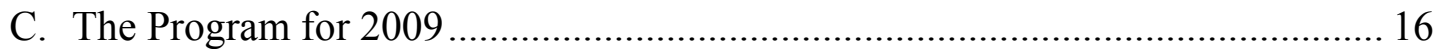

III. Program Modalities .............................................................................................. 22

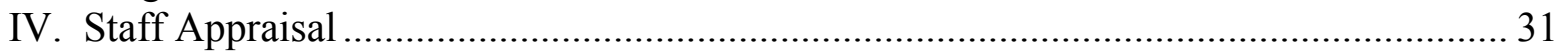

Boxes

1. The Equilibrium Real Effective Exchange Rate in Belarus......................................... 11

2. Banking Sector Stress Tests ........................................................................................ 19

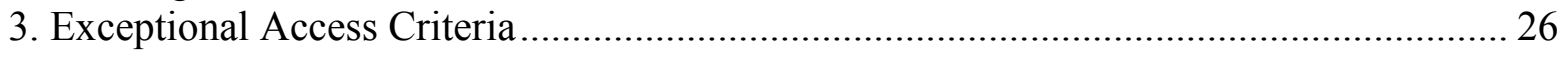

4. Rationale for Proposed Structural Conditionality ........................................................ 30

Figures

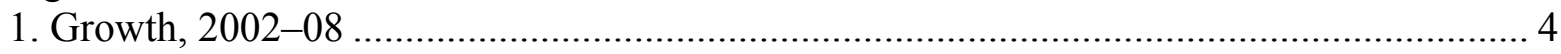

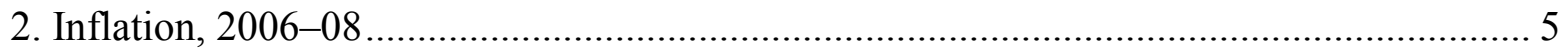

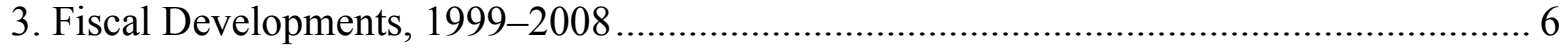

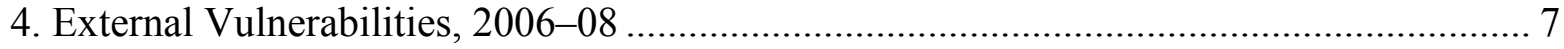

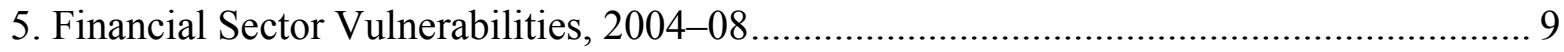

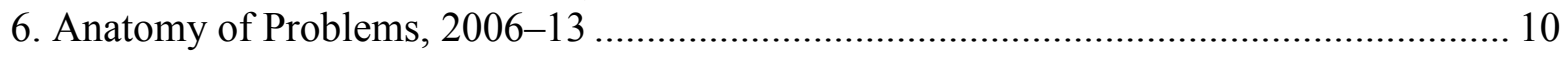

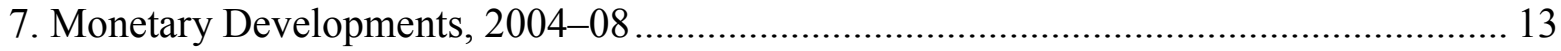

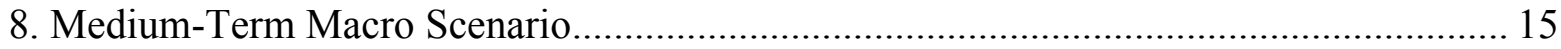

Tables

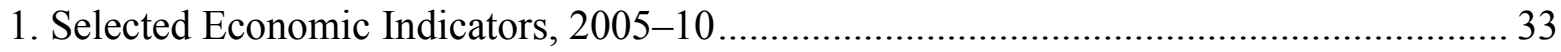

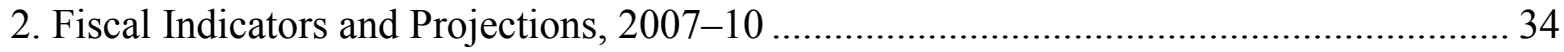

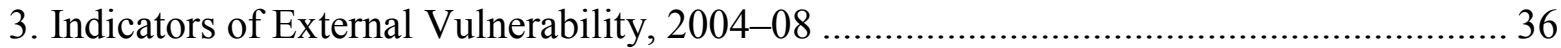

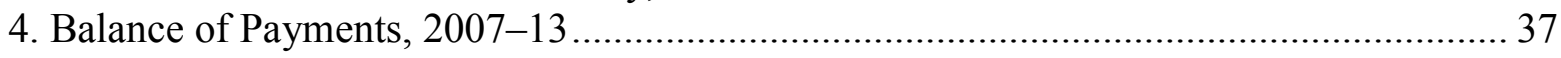

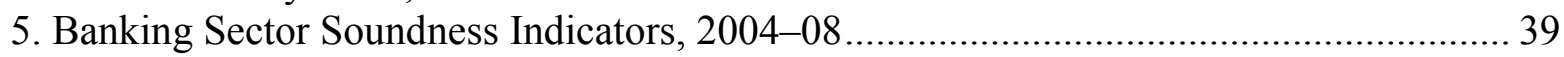

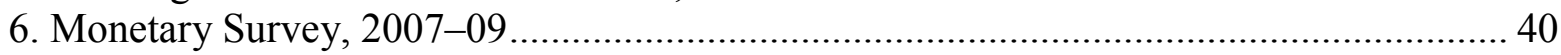

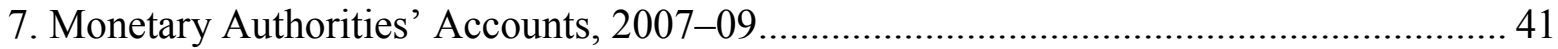

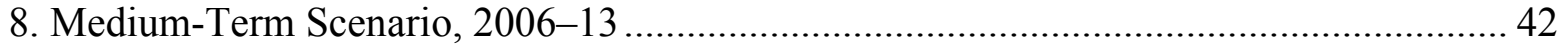

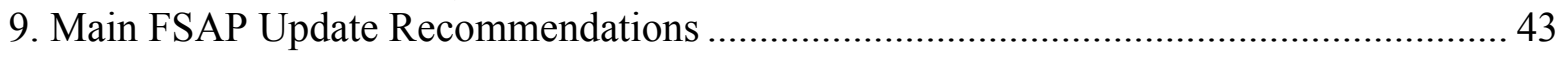

Appendix

I. Debt Sustainability Analysis ........................................................................... 44

II. Letter of Intent, Memorandum of Economic and Financial Policies, and Technical Memorandum of Understanding 


\section{INTRODUCTION}

1. Despite lagging structural reforms, Belarus' growth has been impressive (Table 1; Figure 1). Belarus' economy, characterized by government control over a wide range of activities, receives aggregate EBRD transition scores that are among the lowest. Nonetheless, growth has averaged close to 9 percent since 2002, with spare capacity and high investment underpinning production growth, and a combination of sharp export price gains, strong growth in trading partners, and large energy subsidies from Russia supporting demand.

\begin{tabular}{|c|c|c|c|c|c|c|c|c|}
\hline & 2001 & 2002 & 2003 & 2004 & 2005 & 2006 & 2007 & $\begin{array}{l}2008 \\
\text { Proj. }\end{array}$ \\
\hline GDP growth (percent change) & 4.7 & 5.0 & 7.0 & 11.4 & 9.4 & 10.0 & 8.2 & 10.5 \\
\hline Domestic demand (percent change) & 10.8 & 6.9 & 10.1 & 13.0 & 11.0 & 13.9 & 12.8 & 14.3 \\
\hline Household consumption + fixed investment (percent change) & -29.7 & 11.0 & 10.0 & 11.2 & 12.8 & 16.5 & 17.6 & 15.7 \\
\hline Terms of trade (percent of GDP) & 2.2 & 12.3 & -0.7 & -0.1 & 5.5 & 1.6 & -2.4 & 3.7 \\
\hline Current account balance (percent of GDP) & -3.3 & -2.2 & -2.4 & -5.3 & 1.4 & -3.9 & -6.8 & -7.6 \\
\hline Fixed capital formation (percent of GDP) & 25.2 & 22.7 & 22.0 & 23.7 & 27.0 & 26.5 & 29.7 & 30.8 \\
\hline
\end{tabular}

Sources: Belarus authorities; and IMF staff calculations.

2. However, recently the economy has been overheating (Figure 2). Since bottoming in 2006 at under 7 percent, inflation has been rising in line with developments in other countries in the region. Despite a tightening of price controls in mid-2007, it currently stands at about 16 percent. The rise in inflation is partly the result of global food and energy shocks, but indicators of domestic demand, high credit growth, and output growth above trend point to an overheated economy.

3. The rise in domestic demand has largely been driven by an expansion of quasifiscal activity. Directed lending through state banks has surged since late 2007, with the flow amounting to $3 \frac{1}{2}$ percent of GDP through end-August 2008. Notwithstanding the fiscal activity off-budget in state banks and enterprises, the public balance sheet remains strong: the many public enterprises do have substantial potential value while public debt is very low, due to the interaction of the boom with budgetary restraint (Table 2; Figure 3).

\section{During the boom, external vulnerabilities were not addressed and financial sector vulnerabilities built up (Table 3 ):}

- In the external sector (Table 4; Figure 4), international reserves remained low: at end2007, they amounted to $1 \frac{1}{2}$ months of imports and 57 percent of short-term debt. Some Russian energy subsidies were unwound (Russia doubled the price of natural gas in 2007, and imposed part of its regular export tax on oil exports to Belarus), but the planned increase in the gas price by Russia will continue to impact Belarus through 2011. Exports to western markets remained concentrated on oil products, while higher value-added exports were mostly to the CIS (with 55 percent of non-energy exports destined for Russia). 
Figure 1. Belarus: Growth,2002-08
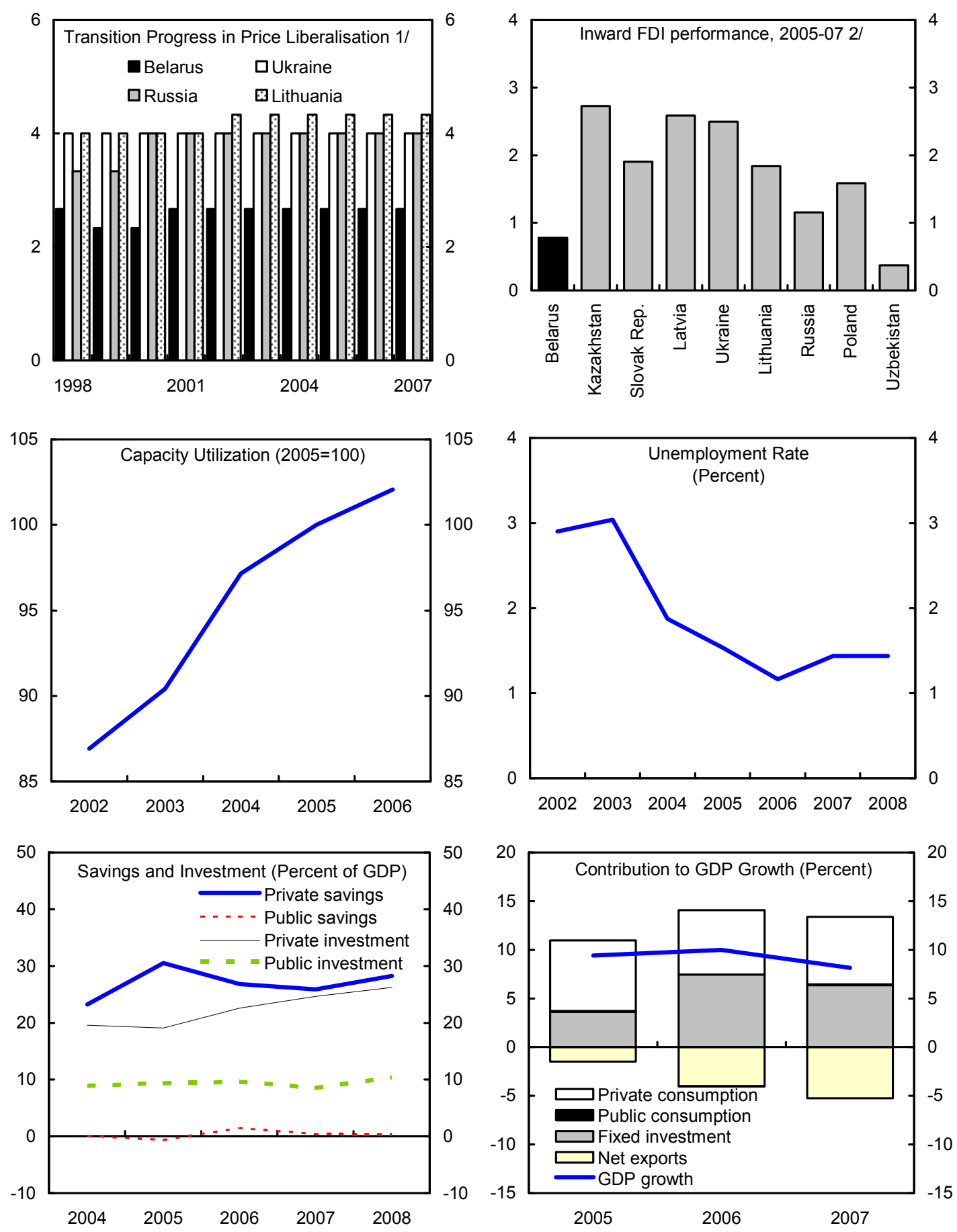

Sources: UNCTAD, World Investment Report, 2008; EBRD, Transition Report, 2008; IMF, World Economic Outlook; Belarus authorities; Boomberg; and IMF staff estimates.

$1 /$ Transition indicators range from 1 to $4+$, with 1 representing little or no change from a rigid centrally planned economy and 4+ representing the standards of an industrialized market economy. Since the turn of the decade, progress in liberalizing prices has stalled in Belarus in comparison with other countries of the region.

2/ The Inward FDI Performance Index ranks countries by the FDI they receive relative to their economic size. It is the ratio of a country's share in global FDI inflows to its share in global GDP. 
Figure 2. Belarus: Inflation, 2006-08

(Year-on-year percent change, unless otherwise indicated)
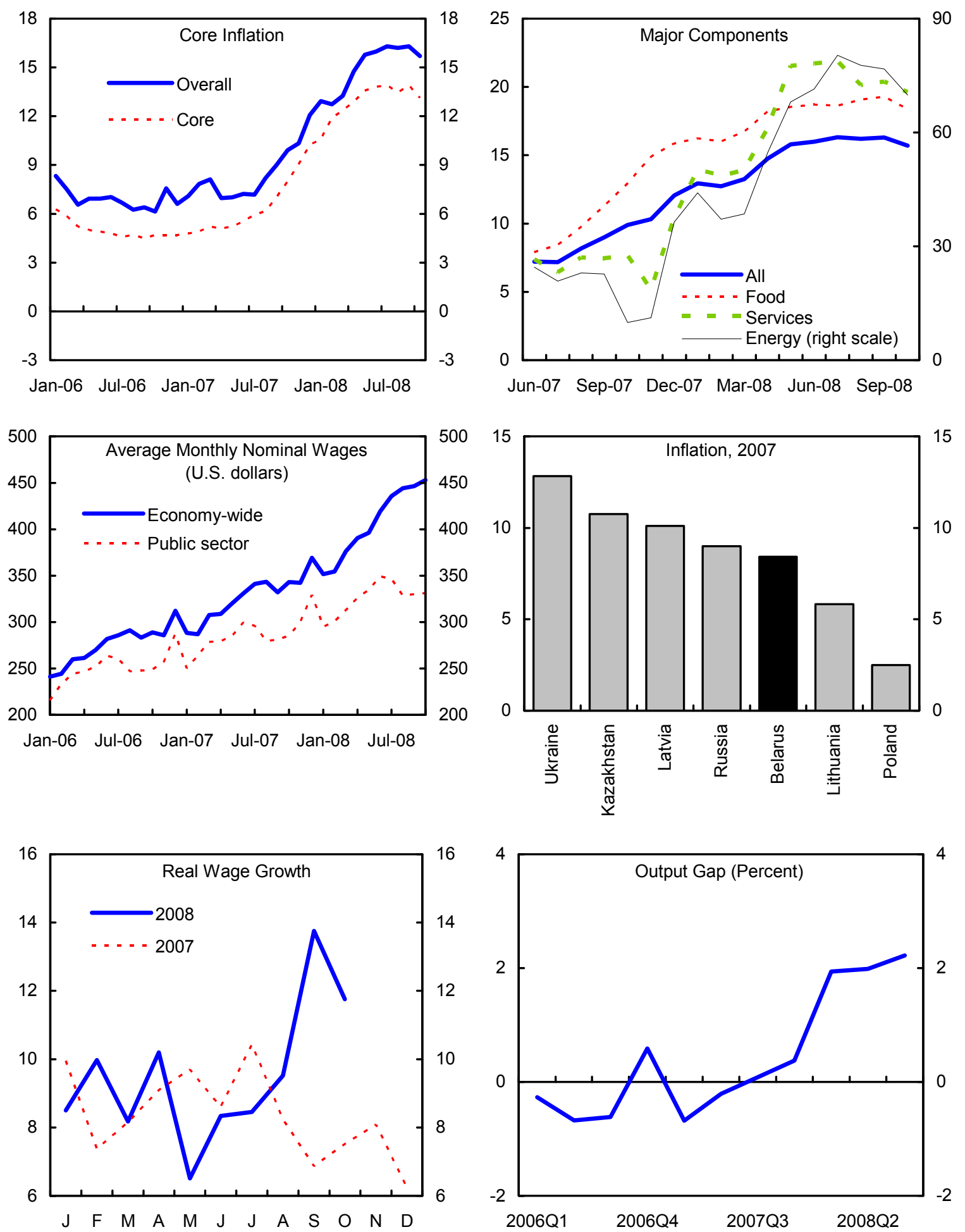

Sources: Belarus authorities; IMF, World Economic Outlook; and IMF staff calculations. 
Figure 3. Belarus: Fiscal Developments, 2004-2008

(Percent of GDP, unless otherwise indicated)
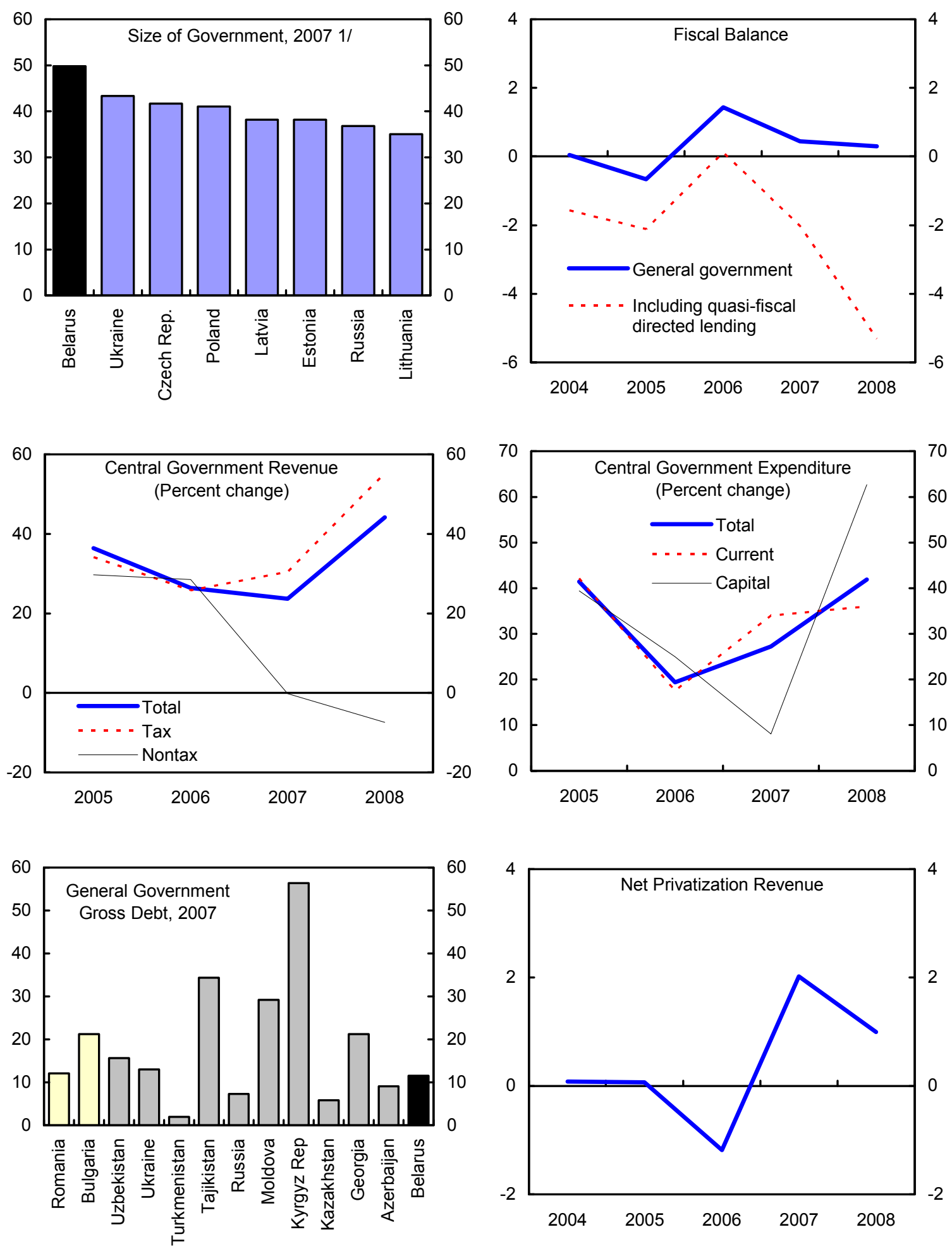

Sources: Belarus authorities; and IMF staff calculations and projections.

1/ Average of general government revenue and expenditure. 
Figure 4. Belarus: External Vulnerabilities, 2006-08
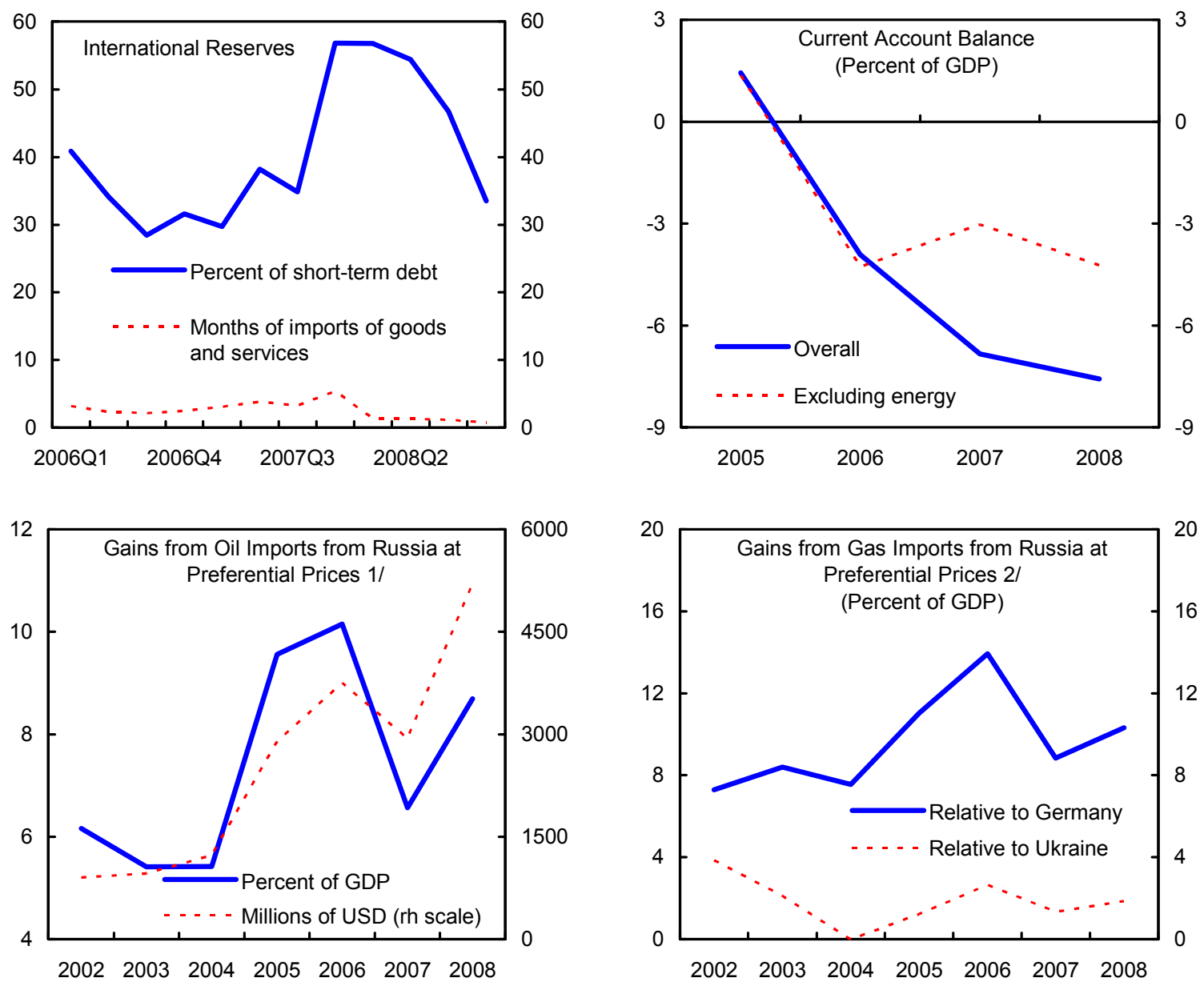

Export Concentration by Geography, 2007

Export Concentration by Product, 2007
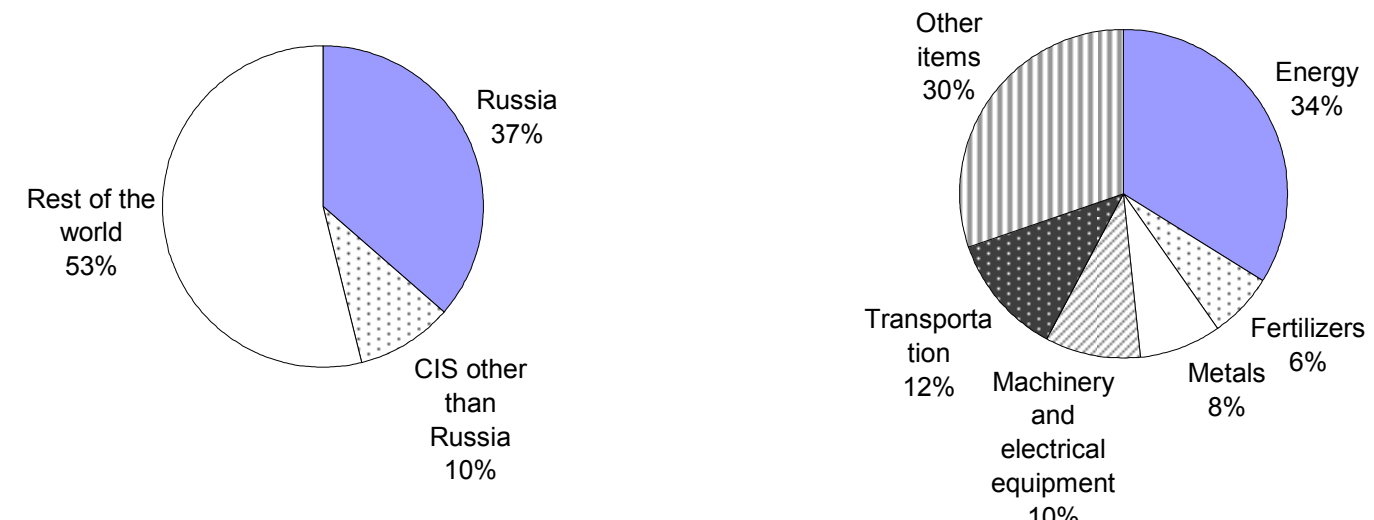

Sources: Belarus authorities; and IMF staff calculations and projections.

$1 /$ Calculated by multiplying the volume of imported crude oil by the diffrerence between the price of Urals brand and the Belarus import price.

2/ Calculated by multiplying the volume of imported natural gas by the difference between Belarus import price and Germany and Ukraine border prices, respectively. 
- In the financial sector (Table 5; Figure 5), indirect credit risks from unhedged foreign exchange borrowing and funding exposure to the global banking system have grown of late, although they remain much smaller than in other eastern European countries (Table 2). However, directed lending increased, funded by government deposits and recapitalization of government-owned banks. Moreover, administratively-imposed interest rate ceilings reduced incentives to manage risk, while high credit growth and low provisioning by banks against NPLs are a source of concern. Overall, the 2008 FSAP Update found that credit and liquidity risk remained high.

5. Recent global developments have exposed these vulnerabilities (Figure 6):

- $\quad$ Falling global energy prices will reduce Belarus' ample profits from exporting refined oil products, while the gas subsidy from Russia will be further reduced. The total terms of trade will deteriorate by 1.1 percent of GDP in 2009, to which the gas price increase will contribute about 1 percent of GDP.

- $\quad$ Exports have recently slowed, reflecting a sharp drop in the price of oil products and fertilizers, as well as a deceleration in partner-country growth. A build up of inventories, contributing about 2 percentage points to GDP in the year to November, has so far prevented a corresponding drop in production.

- The nominal effective exchange rate has jumped sharply, driven largely by dollareuro movements and depreciation of the Russian ruble. Updated staff estimates, incorporating this and commodity price developments, suggest that the real effective exchange rate may now be overvalued by 11-14 percent (Box 1).

- $\quad$ Trade credit has emerged as a serious problem. Foreign customers have delayed their payments for Belarus's exports, and trade credit for imports has become harder to access. All told, the net trade credit flow switched from an inflow of US\$650 million in 2007 to an estimated outflow of US\$25 million in 2008.

- $\quad$ Key sources of new external financing have dried up. In the banking sector, credit lines have been frozen for the largest Belarusian bank, and rollover rates are expected to drop below 100 percent. Prospects for FDI have weakened due to the worsened global economic outlook.

6. As a result of these developments, the currency peg to the U.S. dollar came under pressure toward the end of 2008, with the authorities intervening to slow the rate of depreciation. The National Bank of the Republic of Belarus (NBRB) intervened heavily from September on, and official reserves fell from US\$4.6 billion at end-August to US $\$ 3.2$ billion ( 0.9 month of imports and 37 percent of short-term debt) on December 23, 2008, despite the disbursement of the first tranche of a Russian government loan in an amount of US\$1 billion in November, and the transfer of some foreign currency 
Figure 5. Belarus: Financial Sector Vulnerabilities, 2004-08
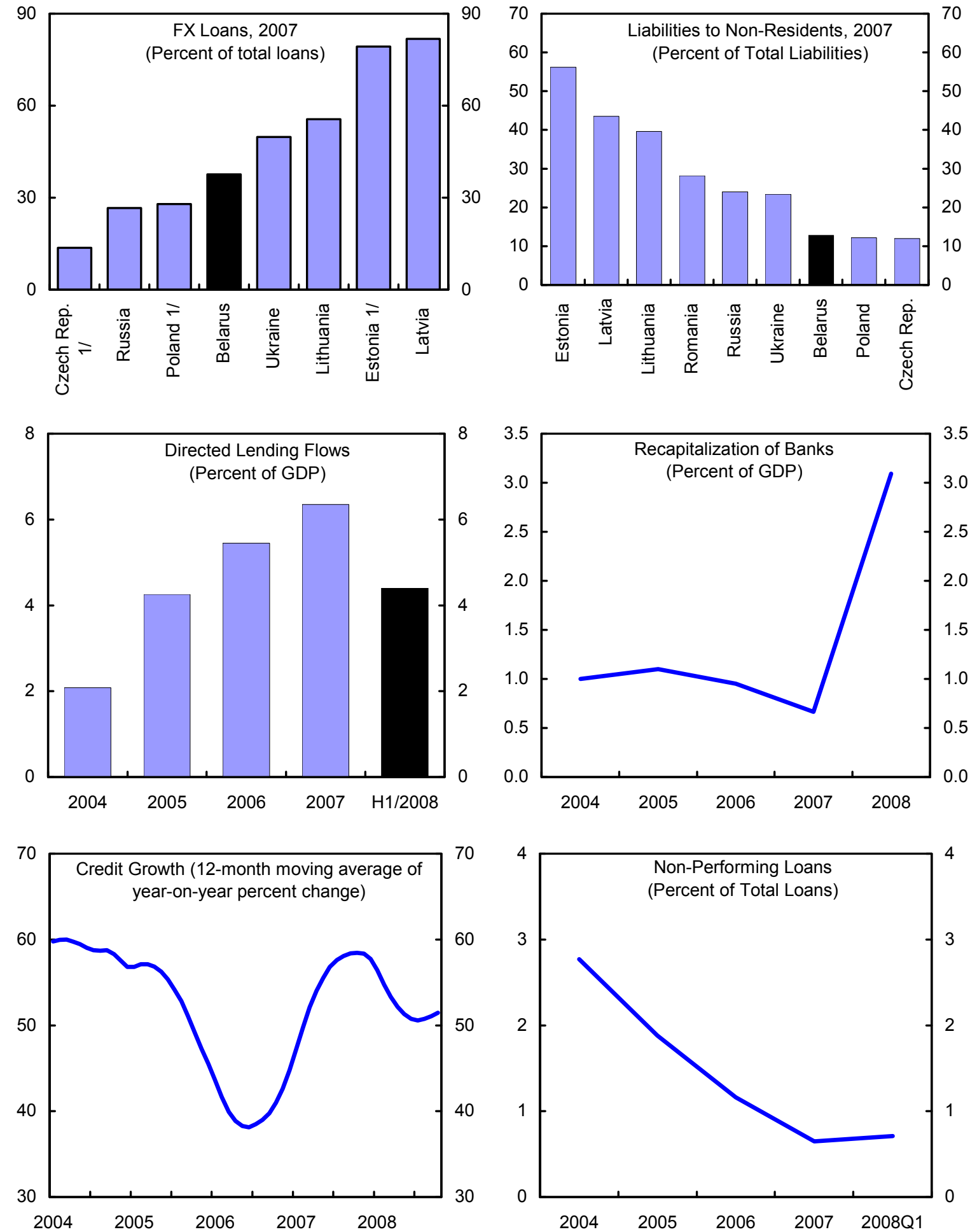

Sources: Belarus authorities; and IMF staff calculations and estimates. 1/ Data for 2007 as of September. 
Figure 6. Belarus: Anatomy of Problems, 2006-13
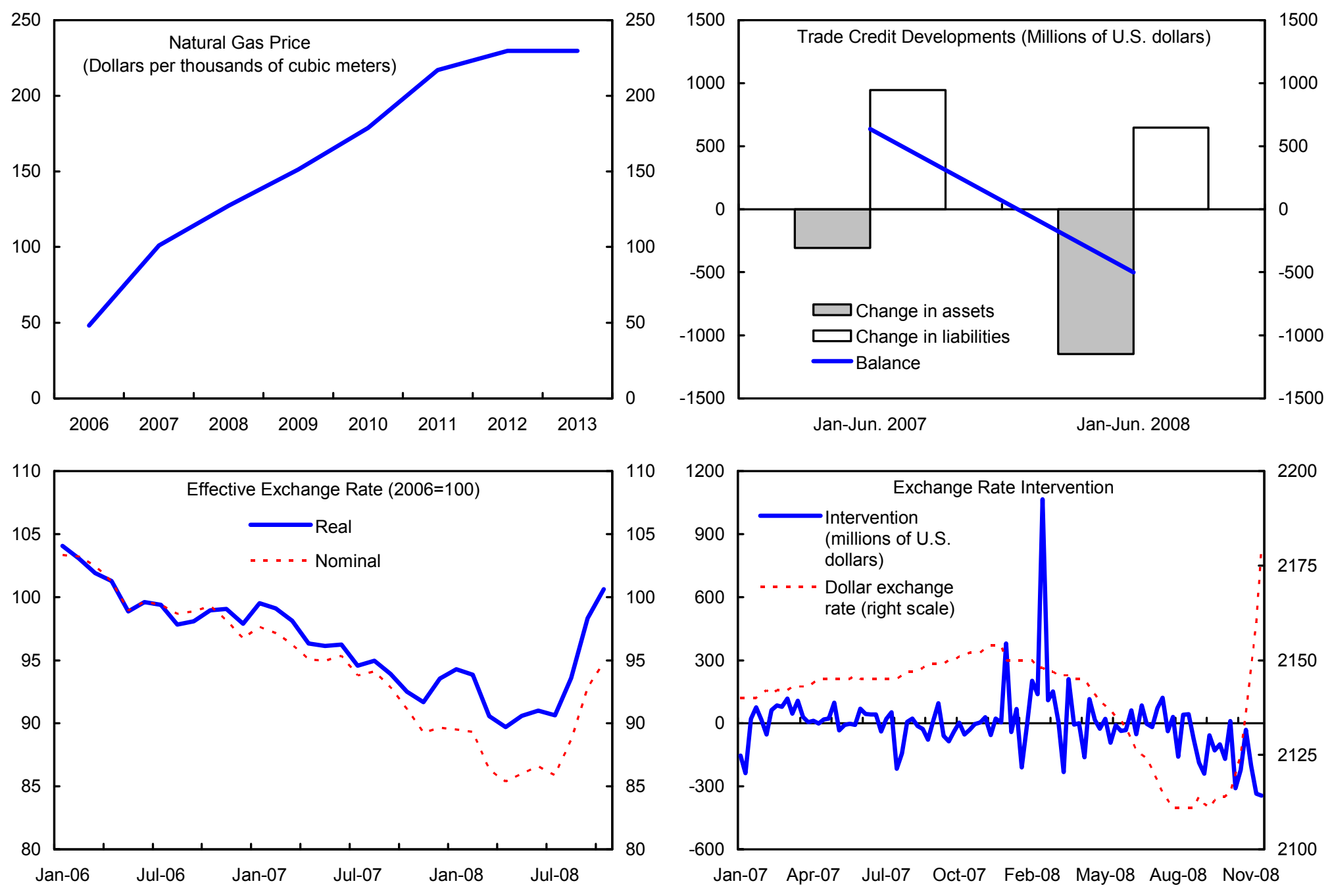

Sources: Belarus authorities; and IMF staff estimates and projections. 


\section{Box 1. The Equilibrium Real Effective Exchange Rate in Belarus}

Indicators suggest that Belarus' real exchange rate is most likely overvalued.

Under the macrobalance approach, the current account norm for a country such as Belarus is -3.6 to -4.7 percent of GDP. The underlying current account (UCA) is estimated assuming: (i) inertia scenario that does not imply adjustment of current policies; (ii) a constant REER (but taking into account the most recent actual movements); and (iii) output growth at potential. To arrive to the UCA, the expected 2008 deficit was adjusted by, first, adding the effects of the permanent energy shocks over the next few years ( 2.5 percent of GDP) and, second, subtracting the deficit caused by the positive output gap - in 2008, growth exceeded its potential by some 2.5 percent and therefore eliminating the gap would reduce the current account deficit by some 1 percent of GDP. The resulting underlying deficit is -9.1 percent of GDP, 4.4-5.5 percent of GDP above the norm. CGER trade elasticities then suggests that the REER is above equilibrium by about 11-14 percent.

The external sustainability approach suggests that stabilizing the net foreign asset (NEAP) position at its existing level of 18 percent of GDP requires a 7.5 percentage point drop in the ratio of the current account deficit to GDP, which implies a 20 percent overvaluation. The current NEAP, however, is somewhat low for a transition country with Belarus' pressing investment needs. Taking a more appropriate (but still prudent) norm of 40 percent of GDP, the gap narrows to 5.1 percentage points, which implies an overvaluation of 13 percent.

A wage-based model suggests that Belarus' real exchange rate was broadly in line with equilibrium for most of 2008 , but that implementation of planned wage increases would leave it overvalued. The panel model controls for measures of productivity and income (e.g., per capita GDP, human capital, share of agriculture, institutional indicators); and other country characteristics that can affect wage levels, such as the importance of oil in exports ${ }^{1}$. The model suggests that large undervaluation in 2000 had vanished by $2007-$

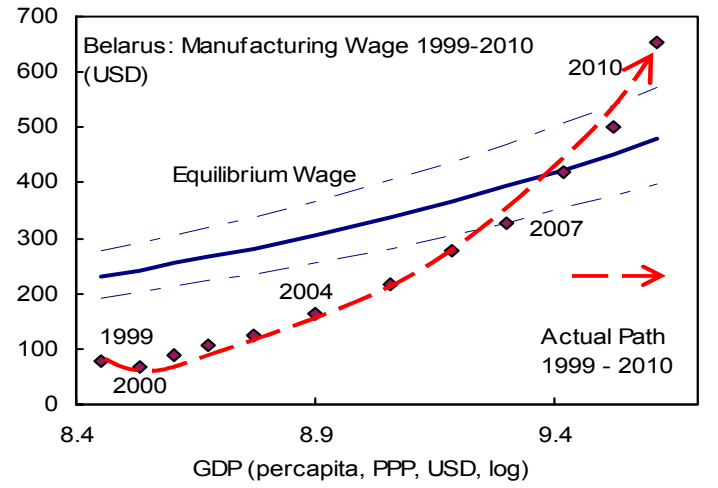
08 , and that if the authorities brought dollar wages to $\$ 570$ by end-2009, as originally announced by the President, the real exchange rate would be overvalued by around 11 percent.

\begin{tabular}{|c|c|c|c|c|c|c|c|c|c|c|c|c|}
\hline \multicolumn{13}{|c|}{ Equilibrium Dollar Wage, 1999-2010 } \\
\hline & 1999 & 2000 & 2001 & 2002 & 2003 & 2004 & 2005 & 2006 & 2007 & 2008 & 2009 & 2010 \\
\hline Actual wage (annual average, U.S. dollars) & 79 & 68 & 90 & 107 & 124 & 162 & 218 & 275 & 326 & 418 & 502 & 655 \\
\hline Equilibrium wage (annual average, U.S. dollars) & 222 & 234 & 250 & 261 & 279 & 301 & 333 & 364 & 393 & 424 & 452 & 478 \\
\hline Equilibrium ratio (percent) & 36 & 29 & 36 & 41 & 44 & 54 & 65 & 76 & 83 & 99 & 111 & 137 \\
\hline
\end{tabular}

Source: IMF staff estimates. 
assets by the NBRB to reserve assets, ${ }^{1}$ as well as introduction of restrictions on pre-payment for imports. While current account shocks and the global financial crisis were key drivers of the reserve loss, there was also a sizable shift in November-December to foreign currency by households, apparently in response to the NBRB's policy of gradually depreciating the rubel - the currency slowly moved to the bottom of its \pm 2.5 percent band (falling by 4 percent between early August and early December). More recently, the NBRB has raised its main policy rate (floor on Lombard auctions) from 12 percent in October to 18 percent in December, and its re-financing rate from 10.75 to 12 percent.

\section{The banking system has so far eluded trouble, helped by timely measures}

(Figure 7). Deposits continue to grow, and to preempt the risk of a run, the authorities have taken measures: a Presidential decree extended a full guarantee to all household deposits; the NBRB was granted and has used its authority to extend non-collateralized emergency loans to banks, at a penalty rate of 20 percent, recently raised to 23 percent; and the NBRB reduced the mandatory reserve requirements in November, releasing about 1 trillion rubels (the equivalent of almost $\$ 500$ million) in liquidity.

8. Budget policy has been generally prudent. In line with the established practice, the budget, excluding recapitalization of banks, will achieve a zero balance relative to GDP in 2008. The authorities have also amended an initial 2009 budget passed by parliament that implied a highly expansionary set of policies, incorporating large wage increases. The amended budget targets a zero balance for 2009 .

\section{The Authorities' Program}

\section{A. Objectives and Strategy}

9. The program's main objectives are to facilitate adjustment to external shocks and to reduce vulnerability, but it will also include significant structural reforms. To this end, the program contains strong macroeconomic adjustment measures, most of which are implemented upfront to help ensure a rapid restoration of macroeconomic stability. The program also addresses a number of structural issues that are critical to adjustment and the mitigation of vulnerabilities. The authorities and staff agreed that broad-based structural reform to liberalize the economy was needed to boost Belarus' medium-term growth. While the full scope of reforms would be achieved over several years, the achievement of greater macroeconomic stability and the initiation of such reforms already under this program would be the foundation for success in the period ahead. A successor program, perhaps an EFF,

\footnotetext{
${ }^{1}$ The NBRB kept some of its foreign assets in currencies that did not meet criteria for the SDDS definition of official reserves.
} 
Figure 7. Belarus: Monetary Developments, 2004-08

(Through end-October, 2008)
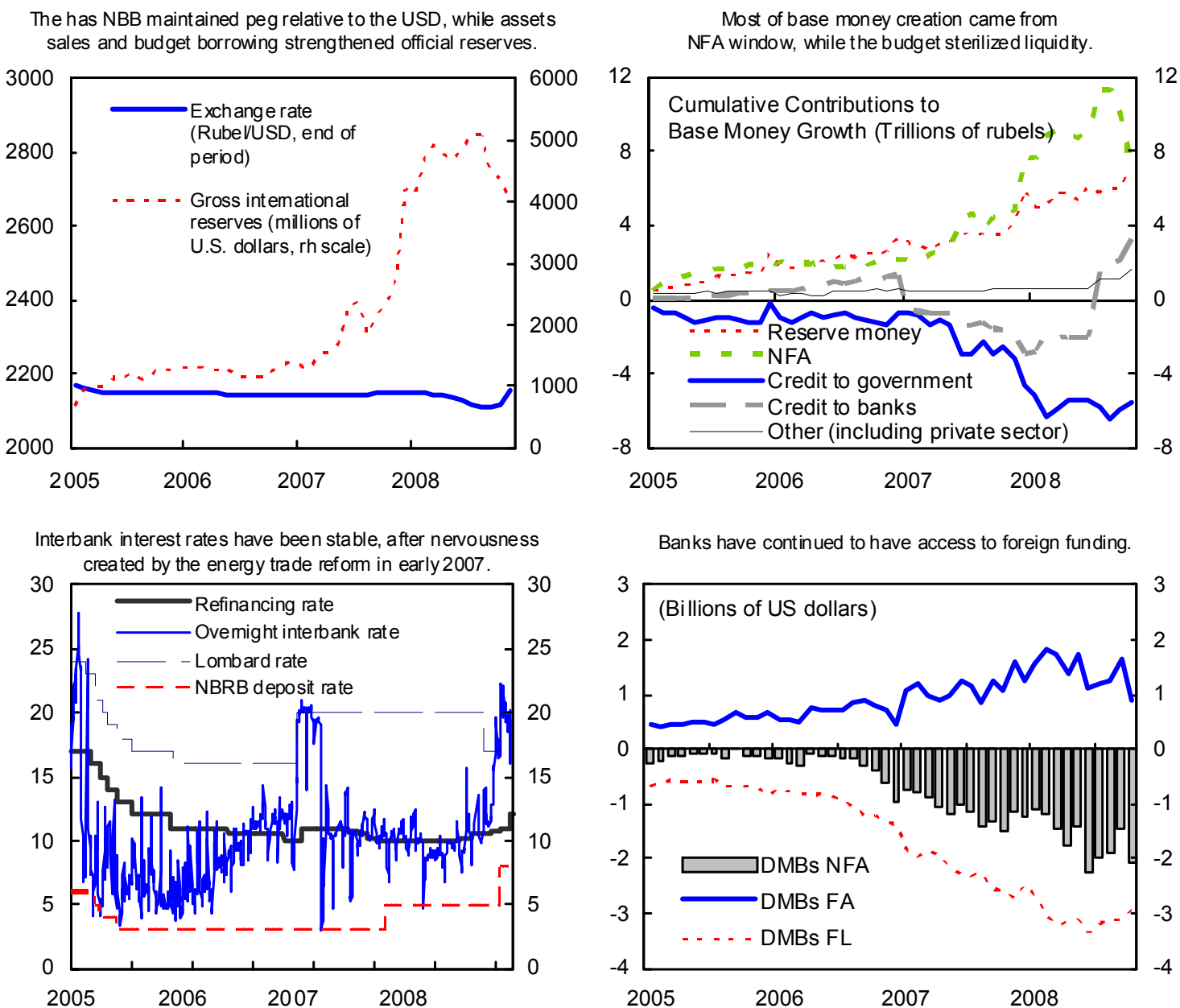

Banks have continued to have access to foreign funding.

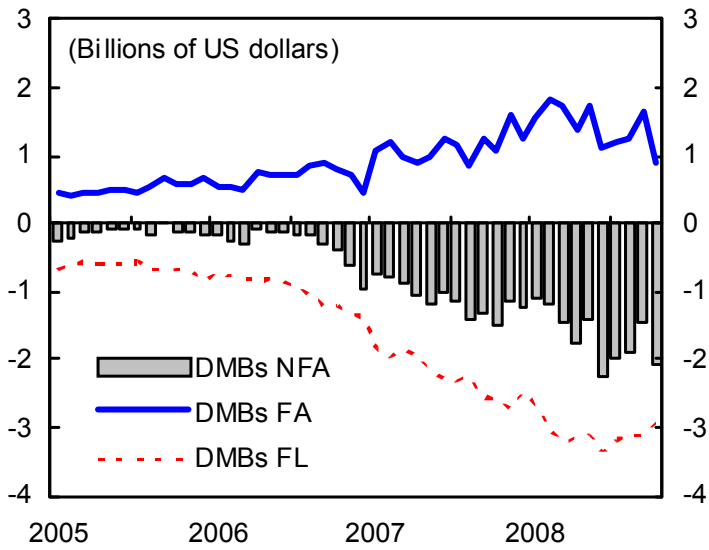

Growth of money and credit was successfully decelerated throughout most of 2007 , but accelerated in early 2008 .
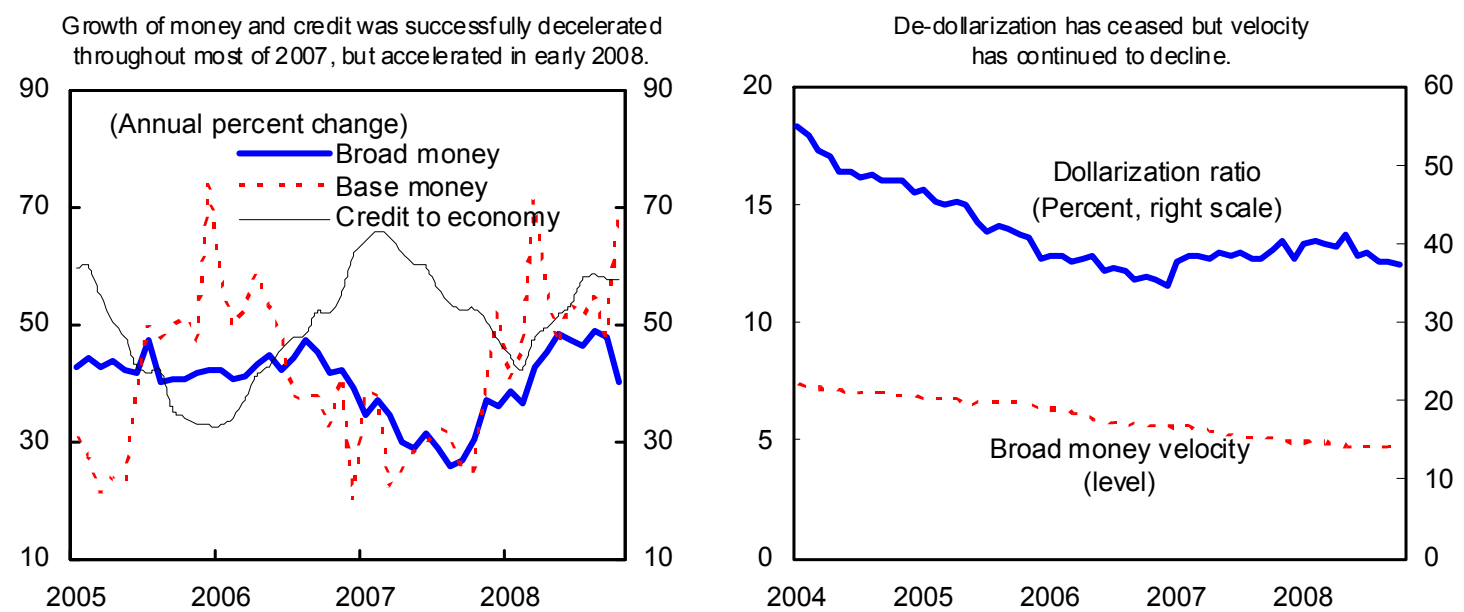

Sources: Belarus authorities; and IMF staff estimates. 
which the authorities indicated they would consider, could support the full range of measures necessary to achieve this objective.

10. The strategy to adjust to external shocks combines an exchange rate realignment with wage-restraint and demand-management measures. Besides improving competitiveness, realignment can quickly restore stability to the capital accountdiscouraging speculative outflows, primarily via conversion of ruble deposits into foreign currency. Supporting wage and demand measures can quickly reduce current account pressures via containing import demand, and can also improve competitiveness over time. Given the starting point—-very low reserves and a negative terms-of-trade shock (implying both a financing gap and an adverse effect on the equilibrium exchange rate) - it was agreed that a combination of the two was needed.

11. The strategy to reduce vulnerability is multifaceted. A more robust exchange rate regime-built around a currency basket that would more closely reflect the structure of Belarus trade and finance flows, with a wider band to give more scope for absorbing shocks, would replace the de facto dollar peg. To provide increased buffers, the program targets higher international reserves. The program also envisages structural reforms to put the financial system on a stronger footing, with directed lending programs removed to the budget, restructuring plans agreed for state banks, and interest ceilings lifted. These measures should encourage better management of risk.

\section{Other key structural reforms focus on price liberalization and enhancing the} role of the private sector. Such reforms are key to initiating the long-awaited economic transition, and also needed to establish the basis for the economy to respond more nimbly to economic shocks.

\section{In light of uncertainties, the program has been designed to be flexible in several} ways. The authorities are seeking additional external financing from other multilaterals and from bilateral creditors, and believe that privatization proceeds could exceed program assumptions if there is an improvement in global climate. Under the program, increased finance from these sources would be partly reflected in a less tight fiscal stance, and partly in an additional increase in reserves. The authorities also agreed that were the global environment to prove worse than expected, they would need to take additional market-based measures to support the program's objectives.

\section{B. Macroeconomic Framework}

14. The program foresees a sharp economic slowdown in 2009 (Table 8; Figure 8). The authorities and staff agreed that the driving factors would be the level of available external financing and external demand for Belarus' exports. With exports slowing substantially, the compression of demand needed to reduce imports would also reduce demand for domestic production. Improvement in competitiveness would provide only a limited offset, due to the low responsiveness of the current account to exchange rate 
Figure 8. Belarus: Medium-term Macro Scenario, 2008-2013
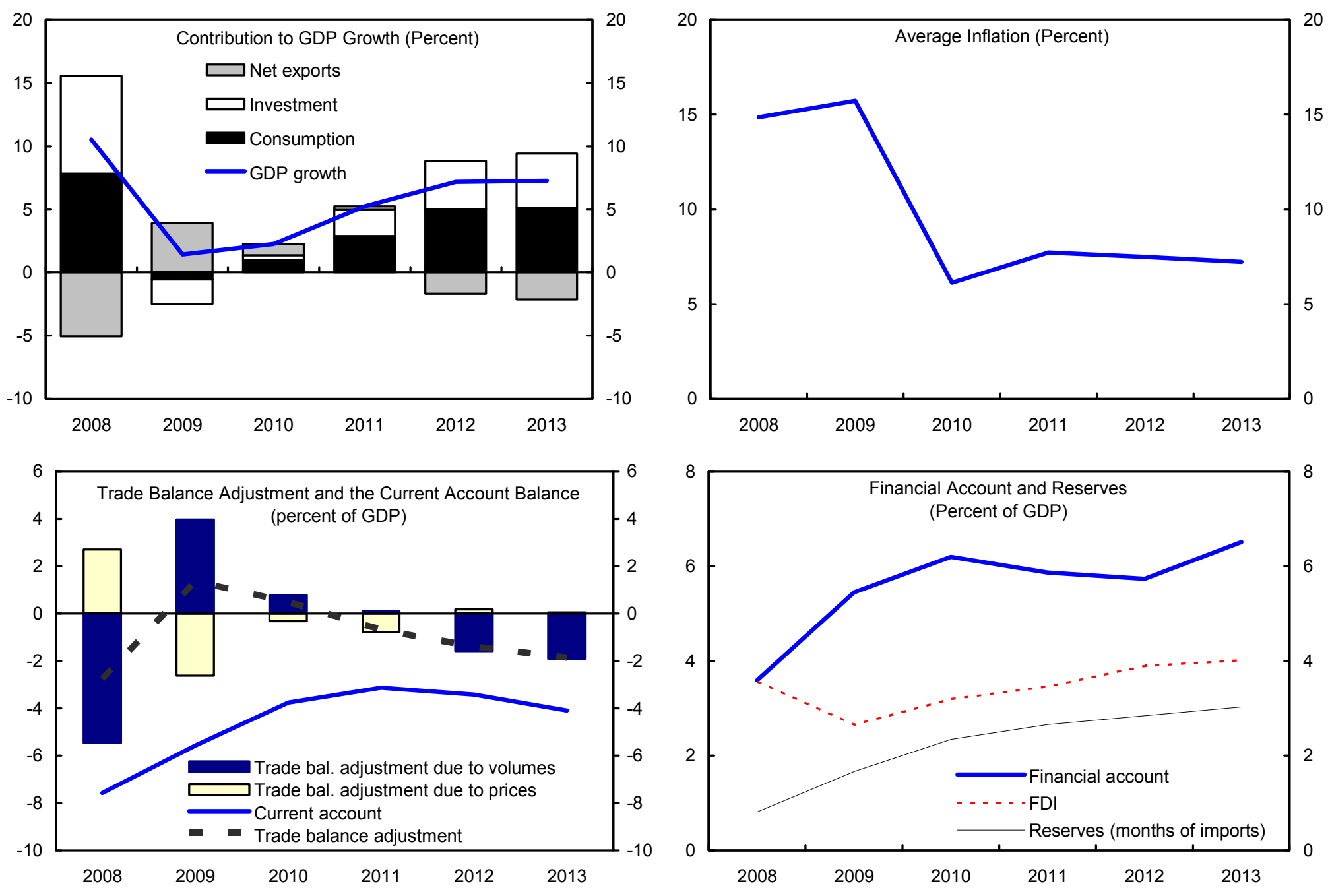

Source: IMF staff projections. 
adjustments (a reflection of Belarus' energy-heavy export basket). Overall, GDP growth could drop to the 1-2 percent range. The combined impact of exchange rate and demand adjustments would bring the current account deficit down to 51/2 percent of GDP in 2009, from an estimated 71/2 percent of GDP in 2008.

15. There was agreement that inflation had to be kept under firm control. Strict

adherence to the policy framework under the program was jointly seen as necessary to contain inflationary expectations in the wake of the exchange rate move, and to prevent an appreciation of the real exchange rate. Reflecting some pass-through of the exchange rate adjustment, the slowdown in the economy, and the abating impact of global food and energy shocks, inflation is projected to slow to $11 \frac{1 / 2}{2}$ percent by end-2009.

16. The pace of recovery of the economy in the medium term is expected to reflect external factors and the authorities' internal liberalization efforts. In the program baseline, which sees recovery beginning in Belarus' key trading partners in late 2009, and which makes no assumptions about an acceleration of structural reforms, growth would return to potential (which is lower than recent growth rates) by 2011. Inflation would be firmly in single digits, the current account deficit would be contained, and reserves would accumulate to safe levels. The authorities and staff agreed, however, that strong liberalization and structural reform efforts, together with greater availability of external finance, would further raise Belarus' growth potential.

\section{The Program for 2009}

\section{Monetary and exchange rate policies}

17. Implementation of a new exchange rate regime is a cornerstone of the program. The dollar peg served the authorities well, but the recent volatility of dollar-euro and dollarruble rates created significant problems: hindering inflation control on the dollar downside early in 2008; and creating competitiveness issues on the recent upside. Yet abandoning the exchange rate as a nominal anchor would be premature. The solution agreed was a step devaluation to a new dollar parity 20 percent below the end-October level, which was implemented on January 1, 2009. This was designed to correct the estimated misalignment and would contribute to closing the external financing gap in 2009, while preserving the nominal anchor role of the exchange rate. The new framework also includes a simultaneous switch to a currency basket (equal weights on the euro, dollar, and Russian ruble), with the new anchor better reflecting the structure of Belarus' trade and financing flows. Furthermore, the widening of the band to \pm 5 percent, also with effect from January 1, 2009, will make the exchange regime better able to absorb further shocks. To guide decisions on intervention within the band, the program supports a floor on the net international reserves of the NBRB, specified to encourage reserve accumulation. 
18. Monetary policy will support the new exchange rate regime, consistent with the inflation target of $11 \frac{1}{2}$ percent. To this end, the authorities have already increased interest rates by about 4 percentage points (Lombard auction rate floor, overnight rate). Moreover, the authorities will eliminate the ceiling on interest rates charged on corporate loans (previously the refinance rate plus 300 basis points). Looking forward, the interest rates will be kept at levels that support the demand for rubel assets, and reduced only as balance of payments and inflation pressures subside. The authorities will also remain prepared to raise interest rates swiftly if necessary to fight outflows. The monetary program will be monitored by a ceiling on

Belarus policy interest rates point at tension on interbank market and drying up rubel liquidity

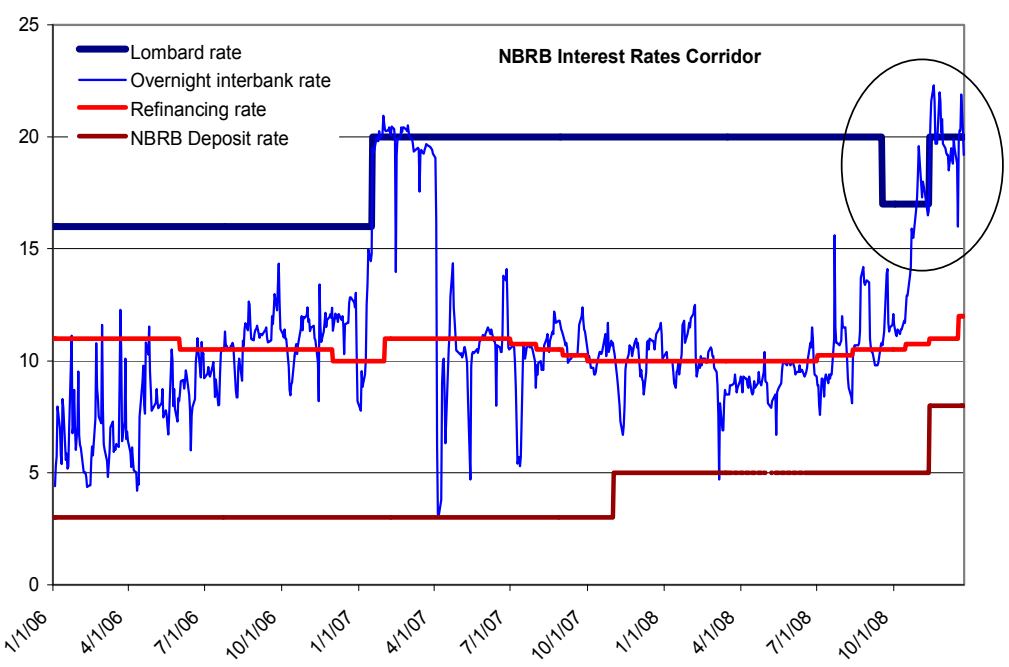
the net domestic assets of the NBRB (derived by reference to base money growth.)

\section{Financial sector policies}

19. The findings of the FSAP Update provided the background to the program discussions on strengthening the financial system (Box 2, Table 9). In line with the key FSAP update recommendations, the program endorses a strengthened contingency framework to deal with potential liquidity or credit risks that may hit the financial sector, and the removal of directed lending from state-owned banks, with a view to making these banks fully adhere to commercial banking principles, with the ultimate objective of privatizing them partly or fully.

20. The framework for crisis preparedness and management has been strengthened. The new blanket deposit guarantee already shields against a run on deposits, and the NBRB has tools to rapidly provide liquidity to banks in need, including through reductions in reserve requirements and/or refinancing. Regarding the latter, the authorities and staff agreed that the NBRB's new uncollateralised lending facility should not evolve into support for insolvent institutions; this facility would only be utilized in exceptional circumstances, and would be complemented by stronger supervision (for example, a requirement for stronger prudential ratios). In addition, the authorities will formalize an institutional framework for dealing with potential crises which would define the roles and powers of various authorities. 


\section{The authorities have also provided a large capital injection to state-owned}

banks. The total injection implemented in December 2008 amounts to $\$ 1.5$ billion (about $2 \frac{1}{2}$ percent of GDP.) This should both compensate losses that the banks will likely experience as a result of the shocks facing the economy and allow the banks to use the injection to repay their outstanding short-term obligations to the NBRB, improving their liquidity indicators. Further action will be needed to tighten loan classification and provisioning requirements which will be brought in line with the best international practices. ${ }^{2}$ If during the program public funds are used to inject further capital to state banks, this would be excluded from calculation of program fiscal deficit targets up to the amounted needed for capital to reach minimum prudential levels.

\section{The program will tackle the long-standing problem of directed lending through}

the banking system. This lending has undermined bank competition, magnified sectoral risk concentrations, reduced incentives for banks (and their borrowers) to manage risks, and has made banks significantly dependent on government funding (deposits and to a lesser extent capital). Under the program, the government will stop increasing its deposits with the state banks, and no new directed lending programs financed in this way will be approved. As the existing stock of directed loans is repaid, the proceeds will be returned to the government account with the NBRB.

\section{Phasing out directed lending will set the stage} for transforming state banks into more marketoriented entities. The authorities intend to hire an advisor to help them prepare state banks for full or partial privatization. The authorities and staff agreed, however, that the pace of actual privatization would depend greatly on the resolution of global banking sector problems. Indeed, potential suitors had asked the authorities for a pause in discussions until conditions settle down.

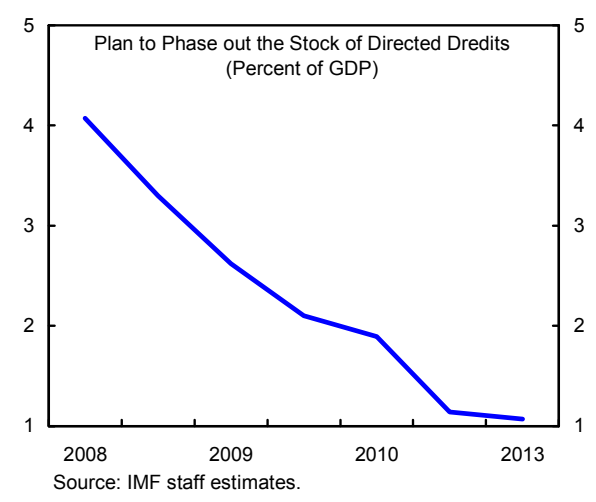

${ }^{2}$ As discussed in the accompanying FSSA Update, the existing loan classification and provisioning requirements in Belarus depart significantly in several areas from the best international standards. In particular, granting a concession to a borrower, such as a prolongation or restructuring of a loan, does not have an impact on loan classification. In the event of an overdue payment, impairment test with respect to other loans granted to the same borrower is not required. Banks are not required to form provisions for the whole balance of nonperforming loan, but only for the portion of loan which is overdue and immediately due. Loans guaranteed by the central and local governments are classified as standard irrespectively of the condition of the borrower and its ability to service the loan. These loans constitute about 25 percent of total loans, and mostly reflect local government-guaranteed agricultural sector loans. At present, the government guarantee can be called upon only after the expiration of the loan maturity (although this provision will not apply to government-guaranteed loans issued after January 1, 2009). 


\section{Box 2. Banking Sector Stress Tests}

The stress tests, which build on FSAP Update work, assumed: (i) a 20 percent devaluation of the rubel; (ii) an increase in interest rates by 500 basis points; and (iii) an increase in the ratio of nonperforming loans to total loans by 10 percentage points. The tests were based on the individual bank data as of end-June 2008 .

\section{The stress tests suggest several conclusions:}

- The direct effects of devaluation would be limited, since banks' net open positions are small, the share of foreign currency denominated loans in total loans is low, and the majority of these loans are channeled to the export-oriented corporate sector. However, credit quality would substantially deteriorate due to the macroeconomic slowdown and increased interest rates (most loans are linked to the NBRB's refinancing rate).

- While the aggregate capital adequacy ratio for all peer groups of banks would stay above 8 percent, it would fall below 8 percent for three state-owned and three foreign-owned banks. Government injection of around BYR 0.5 trillion would be required to raise the capital of these three state-owned banks up to the minimum prudential threshold (though this figure is likely to be lower given the substantial bank recapitalization of December 2008, which was not taken into account in the stress test calculations). Foreign parent banks would need to inject capital of around BYR 0.2-0.3 trillion into their subsidiaries.

- Banks are vulnerable to a potential run on deposits, or a significant reduction in external funding. As a result of a sudden withdrawal of 20 percent of deposits, the aggregate current liquidity ratio, which compares assets and liabilities with a remaining maturity of less than one month, would fall from almost 100 percent to below 50 percent. Large banks would see their current liquidity ratio fall to 33 percent (or $1 / 2$ of the minimum regulatory requirement). A withdrawal of $1 / 4$ of liabilities to non-residents would cause current liquidity of three banks, including 2 large banks, to fall below the minimum.

Table. Belarus: Results of the Macroeconomic Stress Test

\begin{tabular}{lcr}
\hline & \multicolumn{2}{c}{ Capital Adequacy } \\
\cline { 2 - 3 } & \multicolumn{1}{c}{ Actual } & Stressed \\
\hline Total Banking System & 17.1 & 9.7 \\
Large banks & 15.9 & 8.3 \\
Medium Sized Banks & 17.3 & 9.8 \\
Small Banks & 39.4 & 34.4 \\
State owned banks & 16.6 & 9.2 \\
Foreign owned banks & 17.8 & 10.4 \\
Private banks & 32.0 & 26.1 \\
\hline
\end{tabular}

Table. Belarus: Liquidity Stress tests

\begin{tabular}{|c|c|c|c|c|c|c|c|c|c|c|c|c|c|c|}
\hline \multirow[b]{3}{*}{ Current Liquidity Ratio (CLR) $3 /$} & \multirow{3}{*}{$\frac{\text { Total }}{\text { ALL }}$} & \multicolumn{6}{|c|}{ Aggregated liquidity ratios } & \multicolumn{7}{|c|}{ Distribution of banks' individual liqidity ratios } \\
\hline & & \multicolumn{3}{|c|}{ Size 1/ } & \multicolumn{3}{|c|}{ Ownership 2/ } & \multicolumn{4}{|c|}{ Number } & \multicolumn{3}{|c|}{ Share in total assets } \\
\hline & & L & M & $S$ & SOB & FB & PB & $\hat{\circ}$ & 엄 & $\overrightarrow{\hat{N}}$ & $\begin{array}{l}v \\
N\end{array}$ & $\hat{\circ}$ & $\begin{array}{l}\circ \\
\text { in } \\
\end{array}$ & $\begin{array}{l}v \\
N\end{array}$ \\
\hline Baseline ratio (prudential minimum: 70 ) & 97 & 93 & 102 & 146 & 89 & 110 & 157 & 0 & 0 & 9 & 19 & 0.0 & $0.0 \quad 64.4$ & 35.6 \\
\hline \multicolumn{15}{|l|}{ Domestic Withdrawal } \\
\hline Withdrawal of $10 \%$ private sector deposits & 75 & 66 & 94 & 142 & 58 & 104 & 159 & 0 & 3 & 8 & 17 & 0.0 & 60.212 .3 & 27.5 \\
\hline Withdrawal of $20 \%$ private sector deposits & 48 & 33 & 84 & 132 & 18 & 96 & 143 & 2 & 3 & 10 & 13 & 59.9 & 9.822 .7 & 7.6 \\
\hline \multicolumn{15}{|l|}{ Non-Domestic Withdrawal } \\
\hline Withdrawal of $25 \%$ of total liabilities to non- residents & 83 & 80 & 76 & 139 & 79 & 89 & 148 & 1 & 2 & 11 & 14 & 1.2 & 59.926 .6 & 12.2 \\
\hline Withdrawal of $50 \%$ of total liabilities to non- residents & 70 & 68 & 50 & 136 & 68 & 68 & 147 & 1 & 7 & 7 & 13 & 1.2 & $69.5 \quad 17.5$ & 11.8 \\
\hline
\end{tabular}




\section{Fiscal policies}

24. A tight fiscal stance is necessary to contain domestic demand growth. While the headline deficit will be unchanged (at zero), the reduction in directed lending programs will result in a reduction in state support to the economy of about 3 percent of GDP. The authorities have already issued a decree amending the initial 2008 central government budget to reflect the zero deficit target (excluding bank recapitalization costs). The fiscal program will be monitored by quarterly targets on the central government deficit.

\section{Fiscal tightening measures, in some case extended to public enterprises, are aimed directly at slowing investment and consumption:}

- Wage growth will slow in the budget and state enterprise sectors in 2009. Between October 2008 and December 2009, the total nominal wage change in the budget sector will be at most 10 percent, somewhat below inflation over this period, compared to the initial budget plans, which involved some 57 percent of wage increases over the same period. This would deliver 0.6 percent of GDP in fiscal adjustment relative to 2008 . The wage increase in enterprises with a substantial government stake will be limited to 5 percent in 2009 . The benefits of this policy go beyond immediate effects on demand: by late 2009 and into 2010 (when cyclical impacts on productivity begin to abate), the restraint should help improve competitiveness through the unit labor cost channel.

- $\quad$ Public investment will be restrained. Belarus has had very high investment rates compared to its regional peers. The 2009 budget provides for a decline in capital expenditure in nominal terms. Facing financing constraints imposed by the monetary program, and absent access to international financial markets, investment by state-owned enterprises is also expected to decline. Overall, investment will still remain at a comparably high level relative to GDP.

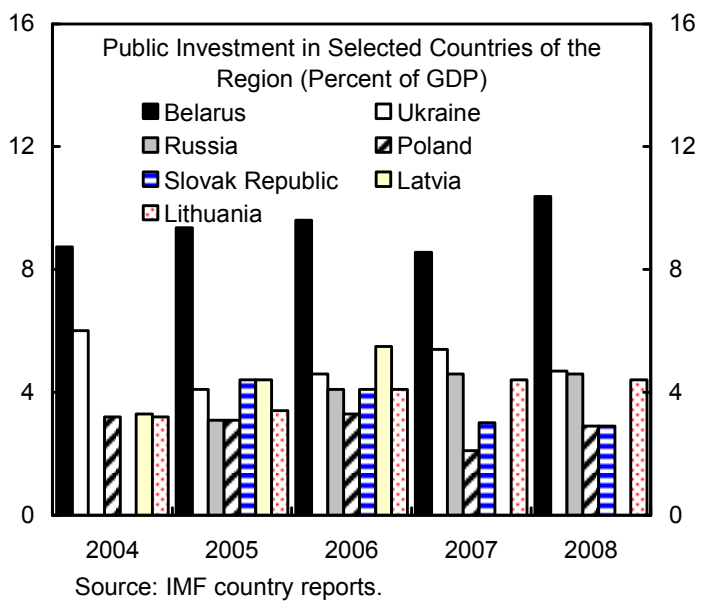
Moreover, focusing restraint in this area provides a good underpinning for the planned fiscal flexibility — it will be easier to delay and bring back projects in line with financing availability, than it would be to effect such a strategy with recurrent spending.

- $\quad$ Subsidies will be curtailed. It will take some time to identify savings from programs previously financed through state banks (interest subsidies to housing and agriculture, set to continue within the budget), and such savings will thus be more likely in 2010 
and beyond. In the near term, the revised budget will reduce subsidies by about 1 percent of GDP. In light of the tight wage policy, the authorities will only gradually move toward increasing cost recovery for housing services, including heating, but will be ready to accelerate price adjustments as the conditions permit.

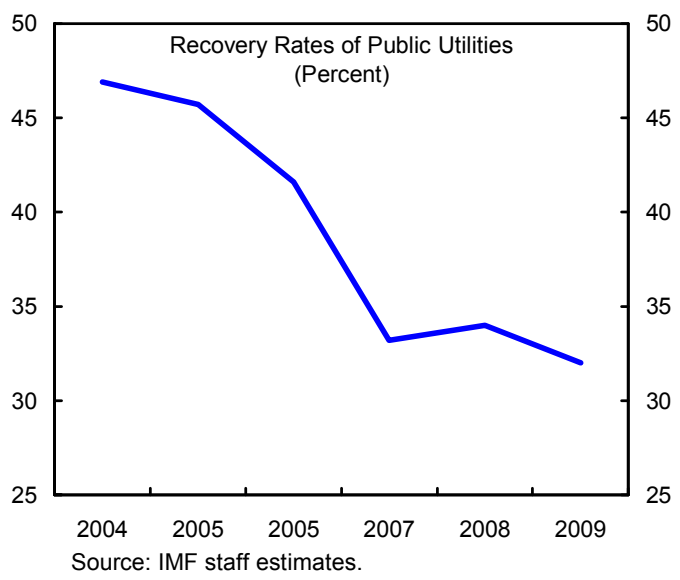

\section{The social safety net will be}

strengthened. Belarus has a high level of social spending, reaching some $13 \frac{1}{2}$ percent of GDP. Nevertheless, to protect the most vulnerable people against the effects of reduced subsidies and the economic downturn, housing assistance for families with 3 or more children, noncash housing subsidies for low-income families, and unemployment assistance will be raised. The authorities are also discussing with the World Bank measures to reduce social risks that might arise as the economy slows and unemployment increases.

Consolidated Budget Expenditures for Social Policy, 2006-09 (Percent of GDP)

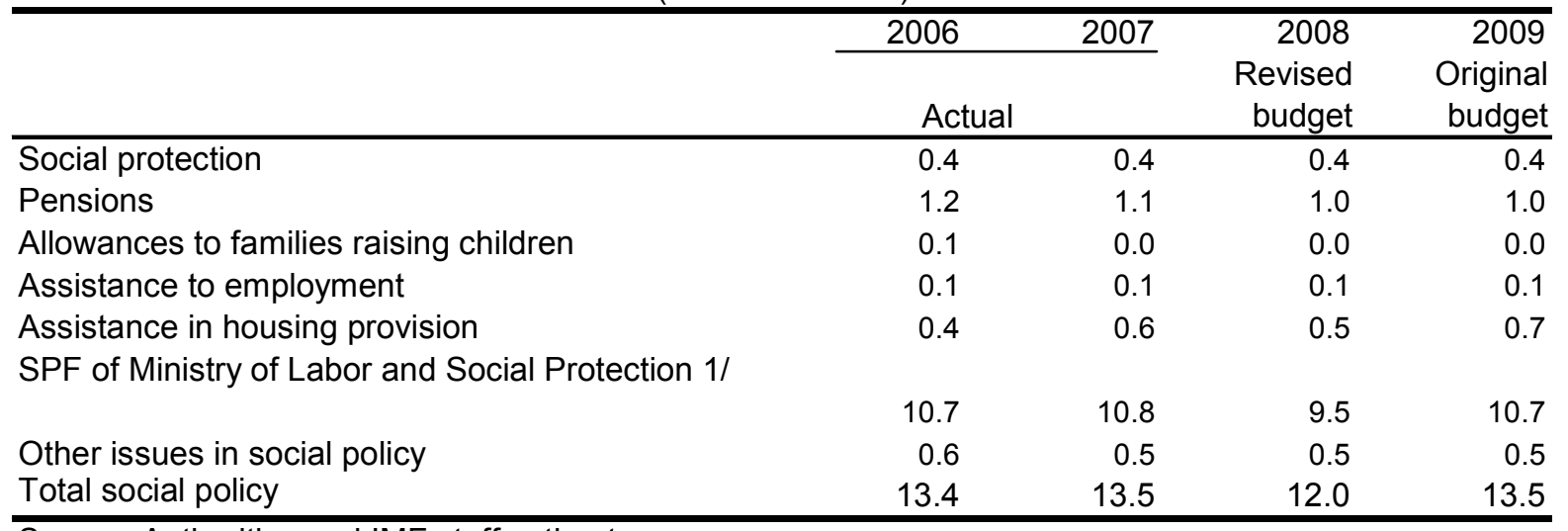

Source: Authorities and IMF staff estimates

1/ The Ministry of Labor and Social Protection administers several programs financed by its Social Protection Fund (SPF). These programs include benefits for old age, disability, and survivors, sickness and maternity, as well as workers' and dependents' medical benefits. Coverage is broad, and not linked to the beneficiary's income level.

\section{Given the uncertainties about economic prospects and the availability of} financing, the authorities stand ready to adjust the fiscal program as needed. Program reviews will consider the broader macro-fiscal picture, including whether shifts in private savings-investment balances necessitate the need, or create space, for adjusting the fiscal program. An adjustor will allow the fiscal stance to accommodate additional external 
financing, should it become available in the second half of 2009, up to a maximum deficit of 1.8 percent of GDP, economic conditions permitting.

\section{Other structural policies}

\section{The authorities and staff agreed that} economic liberalization was a priority, and that it had to be sequenced with macro stabilization reforms. Belarus has long lagged behind its transition peers when it comes to price liberalization. This has costs in terms of resources allocation and economic efficiency, and in particular implies prolonged and more costly adjustment in response to economic shocks. Nevertheless, given the imperative to effect an exchange rate devaluation now, the process of price liberalization would be spread out over 2009-10 to reduce risks of an inflation-

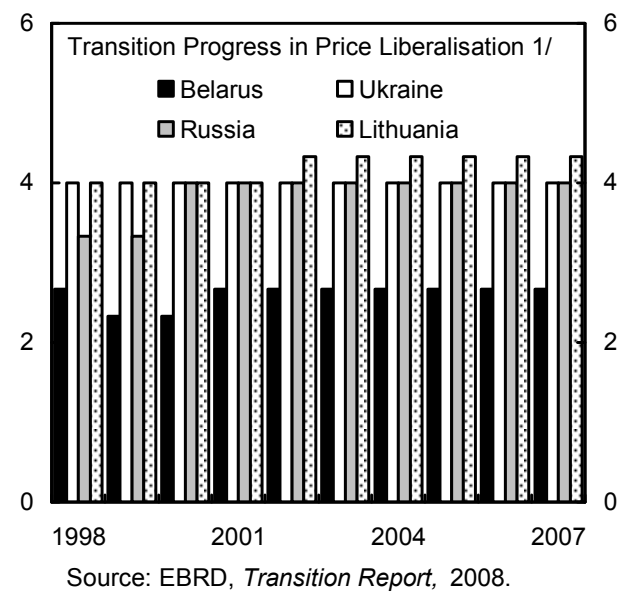
depreciation spiral. In addition to the structural measures mentioned above in the fiscal and financial sector areas, other upfront measures include the scrapping of dollar wage targets and the cancellation of the limit of price increases to $1 / 2$ percent per month by end-March 2009 . This would remove the most broad based of the price control measures and help make the economy more flexible in the present volatile external environment.

\section{The authorities and staff also agreed that a focus had to be kept on enhancing} the role of the private sector. Belarus lags its peers in this area, and improvements would enhance medium-term growth prospects. The authorities' plans in this area include reducing distortive and cascading turnover taxes, reducing the regulatory burden on private companies in which the government holds a small share, and continued efforts to privatize state enterprises and banks.

\section{Program Modalities}

\section{Program financing}

30. Belarus faces very large financing needs during the program period. The staff estimates that as a result of rising energy import prices (as Russian gas subsidies are reduced further), and debt amortizations totaling some US\$3.1 billion, gross external financing requirements would amount to about US\$10.7 billion in 2009 , and about US\$9.5 billion in 2010 . 
Financing Requirements under the Program, 2008-11

(Millions of U.S. dollars)

\begin{tabular}{lrrrr}
\hline & 2008 & 2009 & 2010 & 2011 \\
\hline Financing needs & $-10,388$ & $-10,675$ & $-9,461$ & $-9,696$ \\
Current account balance (baseline) 1/ & $-4,523$ & $-7,478$ & $-6,950$ & $-6,950$ \\
Trade credits (assets) & $-1,400$ & -500 & -200 & -100 \\
Amortization of medium- and long-term loans & $-1,253$ & -716 & -892 & $-1,144$ \\
Short-term loans & $-2,463$ & $-2,397$ & $-1,628$ & $-1,516$ \\
Other investment (net) & -749 & 416 & 208 & 14 \\
Financing sources & 10,388 & 3,238 & 3,862 & 4,907 \\
Capital Account & 120 & 125 & 190 & 148 \\
FDI (net) & 2,130 & 1,523 & 2,011 & 2,487 \\
Portfolio investment (net) & 22 & 20 & 0 & 0 \\
Trade credits (liabilities) & 1,375 & 750 & 650 & 200 \\
Medium- and long-term loans & 2,392 & 1,282 & 2,127 & 2,221 \\
Short-term loans & 2,397 & 1,628 & 1,516 & 1,869 \\
Loans (assets, all sectors) & 79 & 0 & 0 & 0 \\
Errors and omissions & 503 & 250 & 250 & 250 \\
Use of official reserves 2/ & 1,371 & $-2,339$ & $-2,882$ & $-2,268$ \\
Financing gap & 0 & $-7,436$ & $-5,599$ & $-4,790$ \\
Adjustment of the current account & 0 & 4,361 & 4,674 & 4,790 \\
Possible bilateral financing (Russia) & 0 & 1,000 & 0 & 0 \\
Remaining financing to be filled & 0 & 2,075 & 925 & 0 \\
Memorandum item: & & & & \\
$\quad$ Current account (program) & $-4,523$ & $-3,116$ & $-2,276$ & $-2,160$ \\
\hline
\end{tabular}

Source: IMF staff calculations

1/ Baseline current account deficit was estimated by adjusting the 2008 outcome with the energy price shocks as well as a shock related to the slowdown of Russia.

2/ The value in 2008 includes other financing items.

31. In the current climate of global deleveraging, these financing requirements are unlikely to be met from capital inflows. Foreign direct investment will slownotwithstanding the authorities' plans to offer state assets for sale-since potential purchasers face their own financing difficulties. ${ }^{3}$ Identified bilateral financing - the second tranche of a governmental loan from Russia-will deliver $\$ 1$ billion in 2009. A Fund program could trigger additional financing by the EU and the World Bank, but these institutions are not prepared to make firm commitments at this stage. Concerning debt, the

\footnotetext{
${ }^{3}$ Nearly half of the projected receipts of $2 \frac{3}{4}$ percent of GDP in 2009 reflect payments for a privatization deal already finalized in 2008 .
} 
aggregate assumed rollover rate is $60-70$ percent for short-term loans. ${ }^{4}$ As a result, the total available external financing for 2009 would amount to only about US $\$ 4.2$ billion. ${ }^{5}$ Assuming some improvement in global financial conditions, these problems should ease somewhat by 2010 .

\section{The resulting large financing gap can only be partially met by substantial} domestic adjustment and funding from other sources. The current account position is expected to adjust sharply under the program scenario, declining by some US\$4.4 billion relative to the baseline in 2009. Nevertheless, absent Fund financing, official foreign exchange reserves would fall far below the desirable minimum level, and cover only 0.8 months of imports or one third of short-term debt.

\section{Against this background, the authorities are requesting a 15-month Stand-By} Arrangement in the amount of SDR 1.618118 billion (418.77 percent of quota, or \$2.5 billion). Fund financing would cover Belarus' remaining projected balance of payments needs during 2009. An unfinanced gap of $\$ 500$ million remains in 2010, but could be covered in the context of a successor EFF (dealing with Belarus' structural transformation), and by additional financing or measures identified over the course of the next year. The Fund financing in 2009-10 would be utilized to build Belarus' gross international reserves back to a level that is sufficient to cover over 90 percent of short-term debt obligations, and $2 \frac{1}{4}$ months of imports of goods and services) by the end of the program. The arrangement is subject to exceptional access procedures, and (Box 3) evaluates the four substantive criteria.

\section{Capacity to repay the Fund and financial risks to the program}

34. Staff believes that the program would leave Belarus in a position to discharge its obligations to the Fund in a timely manner. While the access requested is substantialaverage annual access for Belarus' proposed arrangement is at the $70^{\text {th }}$ percentile of all highaccess cases, access in relation to other metrics is mostly below the $50^{\text {th }}$ percentile. The high requested access in relation to total external debt results from Belarus' low level of external debt and, in light of no outstanding Fund exposure, mitigates risks to the Fund. However, the level of Fund credit outstanding, at its peak in 2010, would be equivalent to 30.5 percent of Belarus' gross reserves in 2010 which, together with the large financing needs in the medium term, are important risks. Payments to the Fund falling due, at their peak level in 2013, are modestly high at 8 percent of reserves.

\footnotetext{
${ }^{4}$ Within the aggregate rollover rate, there is a wide dispersion among different classes of creditors. For instance, the rollover rate for syndicated loans is assumed to be just 25 percent, while banks are expected to be able to roll over nearly 85 percent of maturing short-term debt to parent banks.

${ }^{5}$ Excluding financing needed to cover the build-up of gross international reserves.
} 
Belarus: Proposed Access

High Access Cases 1/

\begin{tabular}{|c|c|c|c|c|c|}
\hline & \multirow{3}{*}{$\begin{array}{c}\text { Proposed } \\
\text { Arrangement }\end{array}$} & \multicolumn{4}{|c|}{ High Access Cases 1/ } \\
\hline & & \multirow{2}{*}{$\begin{array}{c}\text { Proposed } \\
\text { Arrangement } \\
\text { (Percentile) }\end{array}$} & $\begin{array}{c}\text { 20th } \\
\text { Percentile }\end{array}$ & 80th Percentile & Average \\
\hline & & & \multicolumn{3}{|c|}{ (Ratio) } \\
\hline \multicolumn{6}{|l|}{ Access } \\
\hline In millions of SDRs & 1,618 & 14 & 2,318 & 12,984 & 8,619 \\
\hline Average annual access, percent of quota & 335 & 70 & 119 & 445 & 276 \\
\hline \multicolumn{6}{|l|}{ Total access in percent of: $2 /$} \\
\hline Actual quota & 419 & 37 & 302 & 880 & 635 \\
\hline Gross domestic product & 4.2 & 27 & 3 & 9 & 11 \\
\hline Gross international reserves & 48 & 44 & 27 & 92 & 90 \\
\hline Exports of goods and nonfactor services & 7.2 & 9 & 12 & 45 & 33 \\
\hline Imports of goods and nonfactor services & 6.7 & 8 & 12 & 59 & 34 \\
\hline \multicolumn{6}{|l|}{ Total debt stock } \\
\hline Of which: $\quad$ Public 3/ & 47 & 88 & 7 & 30 & 20 \\
\hline External & 17 & 82 & 6 & 17 & 13 \\
\hline Short-term & 28 & 42 & 20 & 107 & 97 \\
\hline M2 & 30 & 84 & 7 & 24 & 28 \\
\hline
\end{tabular}

Source: executive Board documents, MONA database, and Fund staff estimates.

1/ High access cases include all available data at approval and on augmentation for the 33 requests to the Board since 1994 which involved the use of the exceptional circumstances clause or SRF resources. Exceptional access augmentations are counted as separate observations. For the purpose of measuring access as a ratio of different metrics, access includes augmentations and previously approved and drawn amounts. Access has been rounded to the nearest whole number.

2/ The data used to calculate ratios is the actual value for the year prior to approval for public and short-term debt, and the projection at the time of program approval for the year in which the program was approved for all other variables.

3/ Defined as debt of the central government and debt guaranteed by the central government. 


\section{Box 3. Exceptional Access Criteria}

Belarus' exceptional financing needs stem mainly from the large current account shocks it is experiencing, with the situation increasingly aggravated by capital account pressures. In such cases, the Fund's exceptional access framework requires the proposed access to be justified in light of the four substantive criteria below, but not all of them are required to be met, and the Board has flexibility to grant exceptional access under the exceptional circumstances clause.

\section{Staff assesses that Belarus meets the criteria for exceptional access:}

- Criterion 1 - exceptional balance of payments pressure in the capital account. Belarus is currently experiencing large current account pressures due to adverse terms-of-trade developments and a considerable decline in the demand for its exports. In addition, lower rollover of bank credit and faltering prospects for FDI are expected to result in a significant decline in capital inflows. Supporting the authorities' adjustment program and rebuilding the reserves position requires Fund financing beyond normal access levels.

- Criterion 2-sustainable debt position. Preliminary calculations by staff indicate that there is a high probability that debt will remain sustainable. Total external debt, at about 24 percent of GDP in 2008, is low. Furthermore, curtailed access to debt financing and substantial current account adjustment would help maintain Belarus' debt broadly at its 2008 level. The standard bound tests indicates that Belarus' debt situation remains manageable even with a 30 percent depreciation. Belarus' public debt level-less than 6 percent of GDP - is negligible (Appendix I).

- Criterion 3-access to private capital markets. Belarus's primary sources of financing are: access to bilateral loans, access of foreign bank subsidiaries to their parents banks, and FDI. Belarus does not have access to international financial markets, although successful implementation of the program could allow Belarus to gain some access to private capital markets by the time repurchase obligations to the Fund become due. By that point, the substantial adjustment of the current account, and anticipated recoveries in Belarus' main trading partners should place Belarus' economy on a stronger footing. The authorities' planned liberalization measures and accelerated privatization program would also help underpin stronger FDI.

- $\quad$ Criterion 4-strong policy reform program. The policies outlined suggest a strong prospect for success. The authorities would be taking strong policy measures, mostly upfront as prior actions, which would demonstrate the authorities' commitment and capacity to deliver. However, for the program to succeed, strict implementation is essential. Even a small deviation from proposed policies would greatly enhance risks. 
Belarus: Capacity to Repay the Fund, 2008-2013 1/

\begin{tabular}{lrrrrr}
\hline & 2009 & 2010 & 2011 & 2012 & 2013 \\
\hline Fund repurchases and charges & & & & & \\
In millions of SDRs & 20.2 & 44.2 & 45.9 & 340.4 & 798.6 \\
In millions of US dollars & 30.7 & 67.3 & 69.9 & 520.0 & $1,223.4$ \\
In percent of exports of goods and NFS & 0.1 & 0.2 & 0.2 & 1.0 & 2.1 \\
In percent of total debt service 2/ & 2.2 & 4.0 & 3.5 & 18.1 & 29.1 \\
In percent of quota & 5.2 & 11.4 & 11.9 & 88.1 & 206.7 \\
In percent of gross international reserves & 0.6 & 0.8 & 0.7 & 4.1 & 8.0 \\
Fund credit outstanding & & & & & \\
In millions of SDRs & $1,343.0$ & $1,618.1$ & $1,618.1$ & $1,320.8$ & 546.1 \\
In millions of US dollars & $2,039.9$ & $2,463.0$ & $2,468.5$ & $2,020.3$ & 837.7 \\
In percent of exports of goods and NFS & 5.8 & 6.2 & 5.4 & 3.9 & 1.4 \\
In percent of quota & 347.6 & 418.8 & 418.8 & 341.8 & 141.3 \\
In percent of gross international reserves & 39.2 & 30.5 & 23.8 & 16.0 & 5.5 \\
Memorandum items: & & & & & \\
Exports of goods and NFS & & & & & \\
Debt service & 34,941 & 39,787 & 45,426 & 51,480 & 57,940 \\
Quota (in millions of SDRs) & 1,380 & 1,698 & 2,019 & 2,876 & 4,210 \\
Quota (in millions of dollars) & 386.4 & 386.4 & 386.4 & 386.4 & 386.4 \\
Gross international reserves (in millions of US dollars & 586.3 & 587.6 & 588.8 & 590.3 & 591.9 \\
US dollars per SDR (period avg) & 5,204 & 8,085 & 10,353 & 12,629 & 15,327 \\
US dollars per SDR (eop) & 1.517 & 1.521 & 1.524 & 1.528 & 1.532 \\
\hline
\end{tabular}

Source: Fund staff calculations.

1/ Assumes repurchases are made on obligations schedule.

2/ Debt service includes interest on the entire debt stock and amortization of medium-and long-term debt

35. There are considerable downside risks to the program, which can be managed by unfailing program implementation and additional measures, if necessary:

- The authorities may be forced to exit from their currency basket corridor. Among other things, sharp cross-currency movements could overwhelm the band, leading to a disorderly devaluation, and substantial bank deposit and capital outflows. ${ }^{6}$ Staff considers that Fund financing and strict adherence to the program (particularly NIR targets) should help mitigate risks. The program thus essentially envisions that the authorities would use the full flexibility given by the band, and could adjust the parameters underlying the new regime.

- External economic and financial developments are highly uncertain. A sharper slowdown in Belarus' major trading partners could entail additional softening of the

\footnotetext{
${ }^{6}$ In this regard, the adoption of a basket makes Belarus less vulnerable to sharp cross-currency movements.
} 
current account and further trade credit problems. A further deepening or long duration of the ongoing process of deleveraging in financial markets could well reduce prospects for a return to market access. Movement within the exchange rate band could provide a buffer. However, the key will be strict implementation of program fiscal targets, and the commitment to adjust policies as necessary. The authorities' willingness to pursue deeper structural reforms in the context of a successor EFF arrangement would also help mitigate risks.

36. Upside risks mainly relate to the reversal of recent capital outflows and higher external financing. In these cases, the program would call for some further reserve build up, and where additional fiscal financing was available, allow for some loosening of the stance (up to a cap) once the prospects for stability are reasonably assured.

\section{Program monitoring}

37. The program will cover 15 months, and be financed with SBA resources. The initial disbursement would be SDR 517.798 million (US\$800 million), reflecting the projected large financing gaps early on in the program. Belarus does not meet the circumstances test for the use of SRF resources, inasmuch as it is not experiencing a capital account crisis. SBA resources, with a longer repurchase period, are also better suited to Belarus' needs in light of the very low initial level of reserves (and the time that will be needed to accumulate reserves to acceptable levels).

Belarus: Schedule of Purchases Under the Proposed Stand-By Arrangement

\begin{tabular}{lccl}
\hline & \multicolumn{2}{c}{ Amount of Purchase 1/ } & \\
\cline { 2 - 3 } Date & 517.798 & 134.01 & Board approval of Stand-By Arrangement \\
\cline { 2 - 3 } January 12, 2009 & 275.080 & 71.19 & Observance of end-March 2009 performance criteria and completion of first review \\
May 15, 2009 & 275.080 & 71.19 & Observance of end-June 2009 performance criteria and completion of second review \\
August 15, 2009 & 275.080 & 71.19 & Observance of end-September 2009 performance criteria and completion of third review \\
November 15, 2009 & 275.080 & 71.19 & Observance of end-December 2009 performance criteria and completion of fourth review \\
February 15, 2010 & $\mathbf{1 , 6 1 8 . 1 1 8}$ & $\mathbf{4 1 8 . 7 7}$ & \\
Total & & \\
Source: Fund staff calculations. & & \\
1/ Assuming maximum proposed access. &
\end{tabular}

38. The authorities committed to a number of prior actions in support of their request. These include: (i) the devaluation of the Belarusian rubel against the U.S. dollar by 20 percent and shifting the exchange rate peg from the U.S. dollar to a basket of currencies; (ii) abolishment of the ceiling on lending rates on rubel loans by banks to the corporate sector; (iii) amendment of relevant legislation to prohibit the central government from making additional transfers to its deposit accounts with the commercial banks; (iv) approval of a central government budget for 2009 targeting a zero budget deficit (accomplished); and (v) limiting wage increases for budgetary workers in November 2008 to 5 percent (accomplished). (Box 4) discusses the rationale for the proposed structural conditions under the program. 


\section{The program will be monitored via quarterly reviews, and via performance criteria and structural benchmarks:}

- The first review of the program is expected to be completed on or after May 15, 2009, and the second review on or after August 15, 2009.

- Quantitative performance criteria include a floor on net international reserves, a ceiling on the net domestic assets of the NBRB, and a ceiling on the central government budget deficit. These performance criteria will be subject to adjustors related to external balance of payments support, external budget support, and privatization proceeds, as applicable. Continuous performance criteria have been set for the non-accumulation of external arrears, and avoidance of exchange restrictions, multiple currency practices, and intensification of import restrictions.

- Two structural benchmarks support the strengthening of the financial sector: (i) the hiring of a consultant to assist in the sale of shares in key state-owned banks; and (ii) in line with FSAP recommendations, bringing loan classification practices in line with best international practices. The program also contain additional structural benchmarks on eliminating the regulatory act imposing a general ceiling on monthly price increases of $1 / 2$ percent and refraining from establishing any new extrabudgetary funds.

40. Safeguards. In line with provisions of the Fund's safeguards assessment policy, the NBRB requested a voluntary assessment, which was completed on April 6, 2004. The assessment identified weaknesses in the NBRB's safeguards framework, in particular in the legal, financial reporting and control areas. An update safeguards assessment has been initiated with respect to Belarus' request for Fund assistance.

41. Exchange control measures. In the context of the first review, staff will complete the assessment of whether the exchange control measures introduced by the authorities, including the restrictions on pre-payment for imports, give rise to exchange restrictions subject to Article VIII, Section 2(a) of the Fund's Articles and whether such restrictions warrant temporary approval by the Executive Board.

\section{Although Belarus' statistics are adequate for effective program monitoring,} some weaknesses could hinder program monitoring. Difficulties in monitoring domestic payment arrears other than on wages, pensions, and social benefits are a source of concern, as partial monitoring under the tight budget for 2009 could lead to build up of domestic arrears. Technical assistance needs in the area of Treasury operations will be discussed in the context of the first review, and IMF technical assistance could help address these shortcomings. Further work is also needed to better reconcile the calculation of the deficit using financing data from the NBRB and above-the-line information on revenue and spending from the Ministry of Finance. 


\section{Box 4. Rationale for Proposed Structural Conditionality}

\section{Monetary and exchange rate policies}

With Russia as its largest trade partner, and the volume of its financial transactions in Russian rubles and euros growing, Belarus' narrow band peg to the U.S. dollar introduces a considerable degree of volatility to its balance of payments on account of movements in the dollar against other major world currencies. This in turn can complicate inflation control or bring the sustainability of the peg into question (particularly in light of low reserve levels). To address this, the program includes as a prior action the devaluation of the rubel against the U.S. dollar by 20 percent and it being repegged to a currency basket (A1, MEFP Table 3).

\section{Banking sector policies}

The largely state-owned banking sector in Belarus does not operate on a market oriented basis, with large volumes of directed lending and interest rate ceilings reducing banks' incentives to manage risk, and undermining their capital base. Conditionality under the program seeks to correct such distortions and strengthen the banking system, by eliminating the flow of new resources to fund such lending (A2, MEFP Table 3), and the two remaining programs funded in the past with these deposits will be discontinued or brought on the budget. The program also includes a performance criterion on eliminating the interest rate ceilings (A5, MEFP Table 3), and a benchmark on engaging advisors to prepare some large state owned banks for privatization (C1, MEFP Table 3), both of which would help reorient the operations of the banking sector to a market basis. The loan classification will be brought in line with best international practices by end September 2009 (C3, MEFP Table 3).

\section{Fiscal policy}

To ensure greater transparency of fiscal policies, the program has a structural benchmark on refraining from establishing any new extrabudgetary funds (C4, MEFP Table 3).

\section{Wage and price controls}

The rapid and efficient response of the Belarusian economy to shocks is impeded by a range of price and wage controls. These controls also raise fiscal risks, given the impact on the revenues of the large state-owned enterprise sector. The program contains a benchmark on eliminating the ceiling on monthly price increases, which is the most blunt and distortive of the current price and wage controls (C2, MEFP Table 3). 


\section{Staff Appraisal}

43. Belarus faces a difficult economic situation due to the interaction of trade and financial shocks with underlying vulnerabilities. Adverse terms of trade movements, falling demand from trading partners, unfavorable dynamics in trade credit, and difficulties in accessing external market-based finance have led to a decline in the already low international reserves. The economy will slow, and adjustment will be necessary to bring demand growth down.

44. The authorities' new program, for which they are seeking support under a Fund arrangement, lays out a strategy to address the challenge. A combination of exchange rate adjustment, fiscal adjustment, and tight wage policies would reduce the current account deficit needs; while reserve accumulation, the move to a more robust exchange rate regime, and a shift toward a market-based financial system would address underlying vulnerabilities. Resolute implementation of the program should help return the economy to a higher growth path by $2010-11$.

45. The shift to a more robust exchange rate framework will help the economy to adjust and will guard against ongoing global problems. The new currency basket and wider bands would help the economy absorb a range of external shocks. The realignment of the parity that accompanied the shift will help restore competitiveness and address external imbalances. In case of additional shocks, it will be important to use the full range of flexibility provided by the band, to adhere to the planned path of reserve accumulation.

46. Monetary policy will need to defend the new exchange rate regime. The increase in interest rates that preceded the shift in the exchange rate regime, and their subsequent further upward adjustment, were the right approach. Moreover, the National Bank will only gradually reduce the interest rates once the balance of payments position improves, and is prepared to further increase them if the new regime comes under pressure. Removal of the interest margin limit will play an important role in tightening policy, and will help in improving risk management going forward.

\section{The frameworks for financial sector liquidity and solvency support will need to}

be refined. The blanket deposit guarantee is welcome and will help prevent liquidity events, but any ex-post liquidity provision via uncollateralized lending needs to be matched with heightened supervision. The classification of and provisioning for non-performing loans needs to be brought in line with the best international practices. Bank capitalization should be carefully scrutinized, with the existing resolution framework and government resources deployed where necessary.

48. It will be crucial to purge the banking system of directed lending. The flows of resources from the government must stop, and the underlying programs should be subsumed under the budget. The NBRB should also cease its own directed lending operations. The 
benefit will be better incentives for banks (and their borrowers) to manage risks, and stronger bank capital positions.

49. Fiscal tightening is needed to bring demand into line with external financing constraints. The planned reduction in directed lending is a key element of this, but a central government budget balance and a prudent wage policy in the broader public sector are also needed. The staff welcomes the planned review of the social safety net in cooperation with the World Bank to ensure that the most vulnerable people are protected against the economic downturn and the effects of utility tariff increases. If more financing becomes available, budget policy could be loosened, but extra accumulation of official reserves should also be achieved.

50. Structural reforms remain a priority but they will need to be sequenced carefully, given the difficult external environment. Price and wage liberalization should follow the realignment of the currency with a delay. The program to enhance the private sector - involving reductions in the size of government, deregulation, and privatization — will underpin better medium-term growth, and should be undertaken as fast as market conditions allow.

51. The exceptional level of access under the proposed arrangement (418.77 percent of quota) addresses Belarus' balance of payments financing needs while keeping Fund exposure manageable. The program will help Belarus build up reserves to safe levels (against which Fund exposure would remain manageable), and the external debt would remain small and sustainable. There are risks to the authorities' program—particularly related to management of the transition to a new exchange rate regime-but these can be contained with strict program implementation.

52. In view of Belarus's balance of payments financing needs and the strong policies proposed by the authorities, including their willingness to take contingent measures to address risks, the staff supports the authorities' request for an arrangement in the amount of SDR 1.618118 billion. 
Table 1. Belarus: Selected Economic Indicators, 2005-10 1/

\begin{tabular}{|c|c|c|c|c|c|c|}
\hline & 2005 & 2006 & 2007 & 2008 & 2009 & 2010 \\
\hline & \multicolumn{6}{|c|}{ (Annual percentage change, unless otherwise specified) } \\
\hline \multicolumn{7}{|l|}{ National accounts and employment } \\
\hline Real GDP & 9.4 & 10.0 & 8.2 & 10.5 & 1.4 & 2.3 \\
\hline Total domestic demand & 11.0 & 13.9 & 12.8 & 14.3 & -2.2 & 1.3 \\
\hline Consumption & 10.1 & 9.0 & 9.7 & 10.7 & -0.7 & 1.4 \\
\hline Private & 15.0 & 13.0 & 13.3 & 14.0 & -1.0 & 1.5 \\
\hline Public & 0.4 & -0.2 & 0.5 & 1.2 & 0.0 & 1.0 \\
\hline Investment & 13.3 & 26.2 & 19.5 & 21.4 & -4.9 & 1.0 \\
\hline Of which: fixed & 19.5 & 26.5 & 19.7 & 20.8 & -5.0 & 1.0 \\
\hline Net exports 2/ & 0.1 & -7.9 & -0.8 & -6.9 & 3.9 & 0.9 \\
\hline \multicolumn{7}{|l|}{ Consumer prices } \\
\hline End of period & 7.9 & 6.6 & 12.1 & 13.7 & 11.5 & 8.0 \\
\hline \multirow[t]{2}{*}{ Average } & 10.3 & 7.0 & 8.4 & 14.9 & 15.7 & 6.1 \\
\hline & \multicolumn{6}{|c|}{ (In percent of GDP) } \\
\hline \multicolumn{7}{|l|}{ External Debt and Balance of Payments } \\
\hline Current account & 1.4 & -3.9 & -6.8 & -7.6 & -5.4 & -3.6 \\
\hline Trade balance & -1.7 & -6.1 & -9.1 & -9.6 & -8.6 & -7.4 \\
\hline Exports of goods & 53.3 & 53.7 & 54.3 & 57.2 & 52.5 & 54.1 \\
\hline Imports of goods & -55.0 & -59.8 & -63.4 & -66.8 & -61.2 & -61.5 \\
\hline Gross external debt & 17.0 & 18.5 & 28.0 & 25.3 & 32.4 & 33.9 \\
\hline Public 3/ & 2.6 & 2.3 & 6.6 & 5.9 & 11.8 & 13.1 \\
\hline Private (banks and state-owned enterprises) & 14.4 & 16.3 & 21.5 & 19.4 & 20.6 & 20.8 \\
\hline \multicolumn{7}{|l|}{ Savings and investment } \\
\hline Gross domestic investment & 28.5 & 32.2 & 33.2 & 36.2 & 32.9 & 32.8 \\
\hline Public & 9.4 & 9.6 & 8.6 & 11.2 & 8.0 & 9.5 \\
\hline Private & 19.1 & 22.6 & 24.6 & 25.1 & 24.9 & 23.3 \\
\hline National saving & 29.9 & 28.3 & 26.4 & 28.7 & 27.4 & 29.2 \\
\hline Public & 8.7 & 11.0 & 9.0 & 10.7 & 8.3 & 8.8 \\
\hline Private & 21.2 & 17.2 & 17.4 & 18.0 & 19.2 & 20.4 \\
\hline \multicolumn{7}{|l|}{ Public sector finance } \\
\hline Central government balance & -1.7 & 0.4 & -0.6 & -0.8 & 0.0 & -1.0 \\
\hline General government balance & -0.7 & 1.4 & 0.4 & -0.5 & 0.3 & -0.7 \\
\hline Revenue & 47.4 & 49.1 & 50.0 & 52.2 & 48.9 & 48.5 \\
\hline Expenditure & 48.0 & 47.6 & 49.6 & 52.7 & 48.6 & 49.2 \\
\hline \multicolumn{7}{|l|}{ Of which } \\
\hline Wages & 8.1 & 8.2 & 8.0 & 6.9 & 6.4 & 6.4 \\
\hline Subsidies and transfers & 9.0 & 9.0 & 10.6 & 10.6 & 9.6 & 8.8 \\
\hline Investment & 9.4 & 9.6 & 8.6 & 11.2 & 8.0 & 9.5 \\
\hline & \multicolumn{6}{|c|}{ (Annual percentage change unless indicated otherwise) } \\
\hline Terms of Trade & 12.3 & 3.9 & -2.5 & 8.7 & -3.5 & 1.6 \\
\hline Real Effective Exchange Rate & -0.1 & -2.0 & -4.4 & -1.1 & -4.8 & -3.5 \\
\hline Official reserves (millions of U.S. dollars) & 1,297 & 1,383 & 4,182 & 2,865 & 5,204 & 8,085 \\
\hline Official reserves (months of imports of goods and services) & 0.9 & 0.7 & 1.6 & 0.8 & 1.7 & 2.3 \\
\hline Official reserves (percent of short-term debt) & 39.3 & 31.6 & 56.8 & 33.5 & 62.2 & 91.5 \\
\hline
\end{tabular}

Sources: Belarusian authorities; and Fund staff estimates.

1/ Assumes exchange rate re-peg to a basket of currencies within a horizontal band, the upfront adoption of policies to reduce domestic demand.

2/ Contribution to growth.

3/ Gross consolidated debt of the public sector (general government, central bank, and guarantees extended to non-financial public enterprises). 
Table 2. Belarus: Fiscal Indicators and Projections1/, 2007-10

(In billion of Belarusian Rubles, unless otherwise indicated)

\begin{tabular}{|c|c|c|c|c|c|c|c|c|c|}
\hline & \multirow{2}{*}{$\begin{array}{r}2007 \\
\text { Act. }\end{array}$} & \multicolumn{2}{|c|}{2008} & \multicolumn{5}{|c|}{2009} & \multirow{2}{*}{$\begin{array}{l}2010 \\
\text { Prog. }\end{array}$} \\
\hline & & Budg & Prog. & $\begin{array}{r}\text { Budg. } \\
\text { Dec. }\end{array}$ & $\begin{array}{c}\text { Prog. } \\
\text { Mar. }\end{array}$ & $\begin{array}{l}\text { Prog. } \\
\text { Jun. }\end{array}$ & $\begin{array}{l}\text { Prog. } \\
\text { Sep. }\end{array}$ & $\begin{array}{l}\text { Prog. } \\
\text { Dec. }\end{array}$ & \\
\hline \multicolumn{10}{|l|}{ 1.State (republican and local) budget } \\
\hline Revenue & 36,627 & 51,455 & 52,393 & 55,644 & 11,395 & 26,210 & 41,510 & 56,977 & 61,387 \\
\hline Personal income tax & 3,081 & 4,003 & 4,267 & 5,474 & 1,000 & 2,301 & 3,602 & 5,002 & 5,490 \\
\hline Profit tax & 3,837 & 6,113 & 6,054 & 6,873 & 1,405 & 3,231 & 5,057 & 7,024 & 7,421 \\
\hline VAT & 8,670 & 11,357 & 11,701 & 14,424 & 2,798 & 6,435 & 10,337 & 13,988 & 14,543 \\
\hline Excises & 3,046 & 4,014 & 4,117 & 4,293 & 939 & 2,159 & 3,468 & 4,693 & 4,852 \\
\hline Property tax & 1,519 & 1,988 & 2,103 & 1,208 & 485 & 1,116 & 1,758 & 2,425 & 2,405 \\
\hline Customs duties & 6,281 & 10,730 & 10,746 & 12,286 & 2,393 & 5,503 & 8,674 & 11,964 & 13,406 \\
\hline Other & 3,689 & 7,328 & 7,440 & 7,309 & 1,527 & 3,512 & 5,536 & 7,636 & 9,118 \\
\hline Revenue of budgetary funds & 6,504 & 5,922 & 5,965 & 3,777 & 849 & 1,952 & 3,077 & 4,244 & 4,151 \\
\hline Expenditure (economic cl.) 2/ & 37,240 & 53,125 & 53,393 & 58,768 & 10,996 & 25,810 & 40,410 & 56,977 & 63,050 \\
\hline Wages and salaries & 7,735 & 8,761 & 8,825 & 11,665 & 2,111 & 4,647 & 7,309 & 9,681 & 10,605 \\
\hline Social protection fund contributions & 2,138 & 2,428 & 2,450 & 3,281 & 594 & 1,308 & 2,057 & 2,724 & 2,984 \\
\hline Goods and services & 6,762 & 9,799 & 9,933 & 11,082 & 2,265 & 5,435 & 8,549 & 11,323 & 12,454 \\
\hline Interest & 389 & 767 & 812 & 1,033 & 365 & 799 & 1,217 & 1,738 & 1,144 \\
\hline Subsidies and transfers & 10,222 & 14,085 & 13,539 & 11,482 & 2,619 & 6,549 & 10,187 & 14,553 & 14,612 \\
\hline Capital expenditures & 8,220 & 13,146 & 14,251 & 11,866 & 1,819 & 4,796 & 7,423 & 12,127 & 15,771 \\
\hline of which: Capital transfers to banks & 0 & 0 & 1,000 & 0 & 0 & 0 & 0 & 0 & 0 \\
\hline Net lending & 1,775 & 1,014 & 1,030 & 439 & 206 & 515 & 721 & 1,031 & 1,661 \\
\hline Other & 0 & 3,125 & 2,552 & 7,920 & 1,017 & 1,760 & 2,947 & 3,800 & 3,819 \\
\hline Balance (economic cl.) 2/ & -613 & $-1,670$ & $-1,000$ & $-3,124$ & 400 & 400 & 1,100 & 0 & $-1,663$ \\
\hline Non-cash bank restructuring measures & 552 & 960 & 2,000 & 0 & 0 & 0 & 0 & 0 & 1,660 \\
\hline Net lending to financial institutions & 1,725 & 4,212 & 4,280 & $\cdots$ & $\cdots$ & $\cdots$ & $\cdots$ & $\cdots$ & $\cdots$ \\
\hline Augmented balance & $-2,890$ & $-6,842$ & $-7,280$ & $-3,124$ & 400 & 400 & 1,100 & 0 & $-3,324$ \\
\hline \multicolumn{10}{|l|}{ 2. Social Protection Fund } \\
\hline Revenue & 11,422 & 14,416 & 14,259 & 17,022 & 4,282 & 8,565 & 12,847 & 17,130 & 19,149 \\
\hline Expenditure & 10,386 & 13,900 & 13,846 & 17,004 & 3,349 & 7,534 & 11,720 & 16,743 & 18,697 \\
\hline Balance (cash) & 1,035 & 516 & 413 & 18 & 934 & 1,030 & 1,127 & 387 & 452 \\
\hline \multicolumn{10}{|l|}{ 3. General government } \\
\hline Revenue & 48,049 & 65,871 & 66,652 & 72,666 & 15,678 & 34,774 & 54,357 & 74,107 & 80,536 \\
\hline Expenditure & 47,627 & 67,025 & 67,239 & 75,772 & 14,344 & 33,344 & 52,130 & 73,720 & 81,747 \\
\hline Balance 3/ & 422 & $-1,154$ & -587 & $-3,106$ & 1,334 & 1,430 & 2,227 & 387 & $-1,211$ \\
\hline Augmented balance of the general government & $-1,855$ & $-6,326$ & $-6,867$ & $-3,106$ & 1,334 & 1,430 & 2,227 & 387 & $-2,872$ \\
\hline 4. Financing (cash) $3 /$ & 1,855 & 6,326 & 6,867 & 3,106 & $-1,334$ & $-1,430$ & $-2,227$ & -387 & 2,872 \\
\hline Privatization & 2,495 & 2,245 & 1,285 & 1,412 & 1,656 & 1,711 & 1,766 & 1,820 & 3,279 \\
\hline Foreign financing, net & 3,091 & 2,180 & 2,136 & 2,565 & 2,650 & 2,650 & 2,650 & 2,650 & 2,650 \\
\hline Domestic financing, net & $-3,732$ & 1,901 & 3,446 & -872 & $-5,639$ & $-5,791$ & $-6,642$ & $-4,856$ & $-3,057$ \\
\hline Banking system & $-1,897$ & 733 & -629 & $-1,646$ & $-3,000$ & $-4,300$ & $-5,300$ & $-3,000$ & $-5,500$ \\
\hline Central bank (incl. IMF) & $-3,985$ & $-1,079$ & $-2,435$ & $-1,646$ & $-3,000$ & $-4,300$ & $-5,300$ & $-3,000$ & $-5,500$ \\
\hline Deposit money banks (incl. SPF) & 2,088 & 1,812 & 1,806 & 0 & 0 & 0 & 0 & 0 & 0 \\
\hline Nonbank & $-1,835$ & 1,168 & 4,075 & 774 & $-2,639$ & $-1,491$ & $-1,342$ & $-1,856$ & 2,443 \\
\hline 5. Financing gap & 0 & 0 & 0 & 0 & 0 & 0 & 0 & 0 & 0 \\
\hline \multicolumn{10}{|l|}{ Memorandum items: } \\
\hline Contingent liabilities (in billion of BYR) & 7,215 & 22,953 & 22,953 & 26,812 & 21,672 & 20,391 & 19,110 & 21,648 & 19,348 \\
\hline Gov. guarantee of comm. banks' credit & 7,215 & 9,547 & 9,547 & 11,152 & 7,638 & 5,728 & 3,819 & 5,728 & 1,909 \\
\hline Gov. guarantees of households' deposits & 0 & 13,406 & 13,406 & 15,660 & 14,034 & 14,663 & 15,291 & 15,920 & 17,438 \\
\hline GDP (trillion of rubels) & 96.1 & 126.4 & 127.7 & 147.6 & 151.6 & 151.6 & 151.6 & 151.6 & 166.0 \\
\hline
\end{tabular}

Source: Ministry of Finance, SPF, and Fund staff estimates.

1/ Data for 2008-09 under the budget columns reflect the authorites' approved budgets. The 2009 will be revised to reflect the authorities' decision

to deliver a balance budget for 2009 . The 2009 program assumes $5 \%$ base wage increases in November 08 and May 09 (the latter if conditions perm

$2 /$ Includes changes in expenditure arrears.

3/ The actual deficits include all the closing expenditure for the year carried out in January of the following year and correspond to

the authorities fiscal year reports. The deficit includes January closing expenditure in the year they were actually paid. 
Table 2. Belarus: Fiscal Indicators and Projections1/, 2007-10 (concluded) (In percent of GDP, unless otherwise indicated)

\begin{tabular}{|c|c|c|c|c|c|c|c|c|c|}
\hline & \multirow{2}{*}{$\begin{array}{r}2007 \\
\text { Act. }\end{array}$} & \multicolumn{2}{|c|}{2008} & \multirow[b]{2}{*}{$\begin{array}{l}\text { Budg. } \\
\text { Dec. }\end{array}$} & \multicolumn{3}{|c|}{2009} & \multirow[b]{2}{*}{$\begin{array}{l}\text { Prog. } \\
\text { Dec. }\end{array}$} & \multirow{2}{*}{$\begin{array}{l}2010 \\
\text { Prog. }\end{array}$} \\
\hline & & Budg & Prog. & & $\begin{array}{c}\text { Prog. } \\
\text { Mar. }\end{array}$ & $\begin{array}{l}\text { Prog. } \\
\text { Jun. }\end{array}$ & $\begin{array}{l}\text { Prog. } \\
\text { Sep. }\end{array}$ & & \\
\hline 1.State (republican and local) budget & 38.1 & 40.7 & 41.0 & 37.7 & 7.5 & 17.3 & 27.4 & 37.6 & 37.0 \\
\hline Revenue & 38.1 & 40.7 & 41.0 & 37.7 & 7.5 & 17.3 & 27.4 & 37.6 & 37.0 \\
\hline Personal income tax & 3.2 & 3.2 & 3.3 & 3.7 & 0.7 & 1.5 & 2.4 & 3.3 & 3.3 \\
\hline Profit tax & 4.0 & 4.8 & 4.7 & 4.7 & 0.9 & 2.1 & 3.3 & 4.6 & 4.5 \\
\hline VAT & 9.0 & 9.0 & 9.2 & 9.8 & 1.8 & 4.2 & 6.8 & 9.2 & 8.8 \\
\hline Excises & 3.2 & 3.2 & 3.2 & 2.9 & 0.6 & 1.4 & 2.3 & 3.1 & 2.9 \\
\hline Property tax & 1.6 & 1.6 & 1.6 & 0.8 & 0.3 & 0.7 & 1.2 & 1.6 & 1.4 \\
\hline Customs duties & 6.5 & 8.5 & 8.4 & 8.3 & 1.6 & 3.6 & 5.7 & 7.9 & 8.1 \\
\hline Other revenue & 3.8 & 5.8 & 5.8 & 5.0 & 1.0 & 2.3 & 3.7 & 5.0 & 5.5 \\
\hline Revenue of budgetary funds & 6.8 & 4.7 & 4.7 & 2.6 & 0.6 & 1.3 & 2.0 & 2.8 & 2.5 \\
\hline Expenditure (economic) 2/ & 38.8 & 42.0 & 41.8 & 39.8 & 7.3 & 17.0 & 26.7 & 37.6 & 38.0 \\
\hline Wages and salaries & 8.0 & 6.9 & 6.9 & 7.9 & 1.4 & 3.1 & 4.8 & 6.4 & 6.4 \\
\hline Social protection fund contributions & 2.2 & 1.9 & 1.9 & 2.2 & 0.4 & 0.9 & 1.4 & 1.8 & 1.8 \\
\hline Goods and services & 7.0 & 7.8 & 7.8 & 7.5 & 1.5 & 3.6 & 5.6 & 7.5 & 7.5 \\
\hline Interest & 0.4 & 0.6 & 0.6 & 0.7 & 0.2 & 0.5 & 0.8 & 1.1 & 0.7 \\
\hline Subsidies and transfers & 10.6 & 11.1 & 10.6 & 7.8 & 1.7 & 4.3 & 6.7 & 9.6 & 8.8 \\
\hline Capital expenditures & 8.6 & 10.4 & 11.2 & 8.0 & 1.2 & 3.2 & 4.9 & 8.0 & 9.5 \\
\hline of which: Capital transfers to banks & 0.0 & 0.0 & 0.8 & 0.0 & 0.0 & 0.0 & 0.0 & 0.0 & 0.0 \\
\hline Net lending & 1.8 & 0.8 & 0.8 & 0.3 & 0.1 & 0.3 & 0.5 & 0.7 & 1.0 \\
\hline Other & 0.0 & 2.5 & 2.0 & 5.4 & 0.7 & 1.2 & 1.9 & 2.5 & 2.3 \\
\hline Balance & -0.6 & -1.3 & -0.8 & -2.1 & 0.3 & 0.3 & 0.7 & 0.0 & -1.0 \\
\hline Non-cash bank restructuring measures & 0.6 & 0.8 & 1.6 & 0.0 & 0.0 & 0.0 & 0.0 & 0.0 & 1.0 \\
\hline Net lending to financial institutions & 1.8 & 3.3 & 3.4 & $\ldots$ & $\ldots$ & $\ldots$ & $\ldots$ & $\ldots$ & $\ldots$ \\
\hline Augmented balance & -3.0 & -5.4 & -5.7 & -2.1 & 0.3 & 0.3 & 0.7 & 0.0 & -2.0 \\
\hline 2. Social Protection Fund & 1.1 & 0.4 & 0.3 & 0.0 & 0.6 & 0.7 & 0.7 & 0.3 & 0.3 \\
\hline Revenue & 11.9 & 11.4 & 11.2 & 11.5 & 2.8 & 5.7 & 8.5 & 11.3 & 11.5 \\
\hline Expenditure & 10.8 & 11.0 & 10.8 & 11.5 & 2.2 & 5.0 & 7.7 & 11.0 & 11.3 \\
\hline Balance (cash) & 1.1 & 0.4 & 0.3 & 0.0 & 0.6 & 0.7 & 0.7 & 0.3 & 0.3 \\
\hline 3. General government & 0.4 & -0.9 & -0.5 & -2.1 & 0.9 & 0.9 & 1.5 & 0.3 & -0.7 \\
\hline Revenue & 50.0 & 52.1 & 52.2 & 49.2 & 10.3 & 22.9 & 35.9 & 48.9 & 48.5 \\
\hline Expenditure & 49.6 & 53.0 & 52.7 & 51.3 & 9.5 & 22.0 & 34.4 & 48.6 & 49.2 \\
\hline Balance $3 /$ & 0.4 & -0.9 & -0.5 & -2.1 & 0.9 & 0.9 & 1.5 & 0.3 & -0.7 \\
\hline Augmented balance of the general government & -1.9 & -5.0 & -5.4 & -2.1 & 0.9 & 0.9 & 1.5 & 0.3 & -1.7 \\
\hline 4. Financing (cash) $3 /$ & 1.9 & 5.0 & 5.4 & 2.1 & -0.9 & -0.9 & -1.5 & -0.3 & 1.7 \\
\hline Privatization & 2.6 & 1.8 & 1.0 & 1.0 & 1.1 & 1.1 & 1.2 & 1.2 & 2.0 \\
\hline Foreign financing, net & 3.2 & 1.7 & 1.7 & 1.7 & 1.7 & 1.7 & 1.7 & 1.7 & 1.6 \\
\hline Domestic financing, net & -3.9 & 1.5 & 2.7 & -0.6 & -3.7 & -3.8 & -4.4 & -3.2 & -1.8 \\
\hline Banking system & -2.0 & 0.6 & -0.5 & -1.1 & -2.0 & -2.8 & -3.5 & -2.0 & -3.3 \\
\hline Central bank (incl. IMF) & -4.1 & -0.9 & -1.9 & -1.1 & -2.0 & -2.8 & -3.5 & -2.0 & -3.3 \\
\hline Deposit money banks (incl. SPF) & 2.2 & 1.4 & 1.4 & 0.0 & 0.0 & 0.0 & 0.0 & 0.0 & 0.0 \\
\hline Nonbank & -1.9 & 0.9 & 3.2 & 0.5 & -1.7 & -1.0 & -0.9 & -1.2 & 1.5 \\
\hline \multicolumn{10}{|l|}{ Memorandum items: } \\
\hline Contingent liabilities (in billion of BYR) & 7.5 & 18.2 & 18.0 & 18.2 & 14.3 & 13.5 & 12.6 & 14.3 & 11.7 \\
\hline Gov. guarantee of comm. banks' credit & 7.5 & 7.6 & 7.5 & 7.6 & 5.0 & 3.8 & 2.5 & 3.8 & 1.1 \\
\hline Gov. guarantees of households' deposits & 0.0 & 10.6 & 10.5 & 10.6 & 9.3 & 9.7 & 10.1 & 10.5 & 10.5 \\
\hline GDP (trillions of rubels) & 96.1 & 126.4 & 127.7 & 147.6 & 151.6 & 151.6 & 151.6 & 151.6 & 166.0 \\
\hline
\end{tabular}

Source: Ministry of Finance, SPF, and Fund staff estimates.

1/ Data for 2008-09 under the budget columns reflect the authorites' approved budgets. The 2009 will be revised to reflect the authorities' decision

to deliver a balance budget for 2009 . The 2009 program assumes $5 \%$ base wage increases in November 08 and May 09 (the latter if conditions permit).

$2 /$ Includes changes in expenditure arrears.

3/ The actual deficits include all the closing expenditure for the year carried out in January of the following year and correspond to the authorities fiscal year reports. The deficit includes January closing expenditure in the year they were actually paid. 
Table 3. Belarus: Indicators of External Vulnerability, 2004-08

\begin{tabular}{|c|c|c|c|c|c|}
\hline & 2004 & 2005 & 2006 & 2007 & $\begin{array}{l}2008 \\
\text { Proj. }\end{array}$ \\
\hline $\mathrm{CPI}$ inflation (end year) & 14.4 & 7.9 & 6.6 & 12.1 & 13.7 \\
\hline $\begin{array}{l}\text { Export volume of goods (percent change) } \\
\text { Import volume of goods (percent change) }\end{array}$ & $\begin{array}{l}15.2 \\
21.4\end{array}$ & $\begin{array}{l}-1.2 \\
-3.1\end{array}$ & $\begin{array}{r}8.3 \\
21.7\end{array}$ & $\begin{array}{l}5.2 \\
7.2\end{array}$ & $\begin{array}{r}5.9 \\
16.8\end{array}$ \\
\hline Current account balance (percent of GDP) & -5.3 & 1.4 & -3.9 & -6.8 & -7.6 \\
\hline $\begin{array}{l}\text { Financial account balance (billions of U.S. dollars) } \\
\text { Of which }\end{array}$ & 1.1 & 0.0 & 1.7 & 5.3 & 2.6 \\
\hline Foreign direct investment & 0.2 & 0.3 & 0.4 & 1.8 & 2.1 \\
\hline Trade credits (net) & 0.59 & -0.55 & 0.16 & 0.69 & -0.03 \\
\hline Official Liabilities, net & -0.2 & 0.0 & -0.1 & 2.1 & 0.6 \\
\hline Liabilties of the banking sector, net $1 /$ & 0.2 & 0.2 & 0.5 & 1.1 & 0.2 \\
\hline Gross official reserves (billions of U.S. dollars) & 0.77 & 1.30 & 1.38 & 4.18 & 2.86 \\
\hline Months of imports of goods and nonfactor services & 0.6 & 0.9 & 0.7 & 1.6 & 0.8 \\
\hline Percent of broad money & 18.9 & 22.2 & 16.9 & 36.7 & 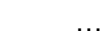 \\
\hline Gross total external debt (billions U.S. dollars) & 5.0 & 5.1 & 6.8 & 12.5 & 15.1 \\
\hline Percent of GDP & 21.8 & 17.0 & 18.5 & 28.0 & 25.3 \\
\hline Percent of exports of goods and nonfactor services & 31.6 & 28.4 & 30.8 & 45.5 & 39.3 \\
\hline Gross short-term external debt (billions of U.S. dollars) & 3.5 & 3.3 & 4.4 & 7.4 & 8.5 \\
\hline Percent of gross total external debt & 70.6 & 64.3 & 64.0 & 58.7 & 56.6 \\
\hline Percent of gross official reserves & 455 & 254 & 317 & 176 & 298 \\
\hline Debt service ratio (percent) $2 /$ & 3.7 & 3.6 & 2.4 & 3.1 & 4.5 \\
\hline REER appreciation (CPI based, period average) & -2.1 & -0.1 & -2.0 & -4.4 & -1.1 \\
\hline Capital adequacy ratio (percent) & 19.0 & 19.0 & 17.3 & 15.5 & \\
\hline Nonperforming loans (percent of total) & 2.8 & 1.9 & 1.2 & 0.7 & 0.7 \\
\hline Real broad money (percent change) $3 /$ & 26.0 & 31.8 & 30.6 & 24.9 & $\cdots$ \\
\hline Real credit to the private sector (percent change) $3 /$ & 40.8 & 37.7 & 43.5 & 36.0 & $\ldots$ \\
\hline Banks' net foreign asset position (billions of U.S. dollars) & $\ldots$ & 0.3 & 0.2 & 0.2 & $\ldots$ \\
\hline
\end{tabular}

Sources: Belarus authorities; and IMF staff estimates and projections.

$1 /$ Includes loans, currency and deposits and other flows.

$2 /$ Interest plus medium- and long-term debt repayments in percent of exports of goods and services.

3/ Deflated by the CPI. 
Table 4. Belarus: Balance of Payments, 2007-13 1/

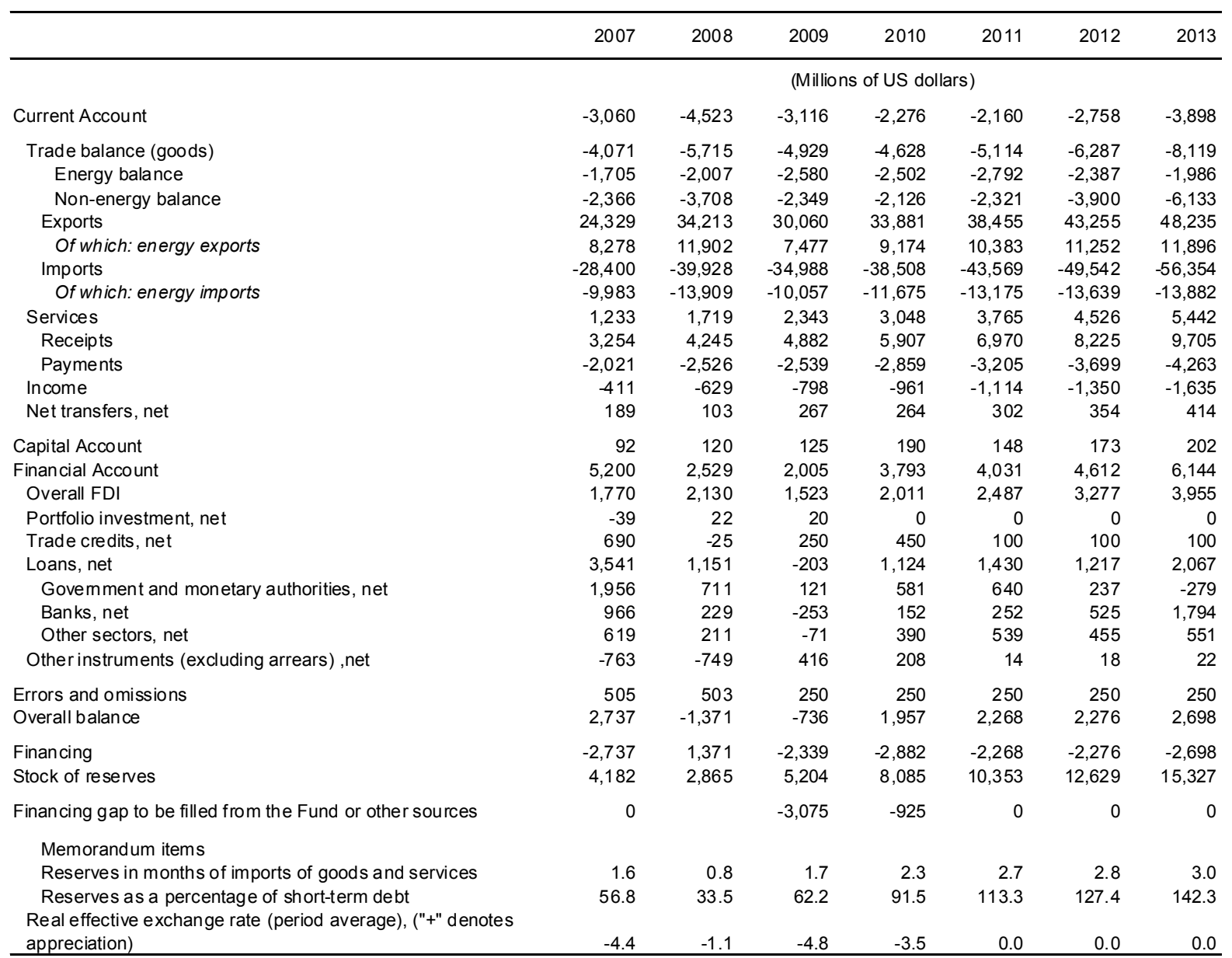

Source: Belarus authorities and Fund staff estimations

$1 /$ Assumes an upfront devaluation and the adoption of expenditure-reducing measures. 
Table 4. Belarus: Balance of Payments, 2007-13 1/ (concluded)

\begin{tabular}{|c|c|c|c|c|c|c|c|}
\hline & 2007 & 2008 & 2009 & 2010 & 2011 & 2012 & 2013 \\
\hline & \multicolumn{7}{|c|}{ (Percent of GDP) } \\
\hline Current Account & -6.8 & -7.6 & -5.4 & -3.6 & -3.0 & -3.3 & -4.0 \\
\hline Trade balance & -9.1 & -9.6 & -8.6 & -7.4 & -7.1 & -7.5 & -8.3 \\
\hline Of which: energy balance & -3.8 & -3.4 & -4.5 & -4.0 & -3.9 & -2.8 & -2.0 \\
\hline Non-energy balance & -5.3 & -6.2 & -4.1 & -3.4 & -3.2 & -4.7 & -6.3 \\
\hline Exports & 54.3 & 57.2 & 52.5 & 54.1 & 53.7 & 51.6 & 49.2 \\
\hline Of which: energy exports & 18.5 & 19.9 & 13.1 & 14.6 & 14.5 & 13.4 & 12.1 \\
\hline Imports & -63.4 & -66.8 & -61.2 & -61.5 & -60.8 & -59.1 & -57.5 \\
\hline Of which: energy imports & -22.3 & -23.3 & -17.6 & -18.6 & -18.4 & -16.3 & -14.2 \\
\hline Capital and financial accounts & 11.8 & 4.4 & 3.7 & 6.4 & 5.8 & 5.7 & 6.5 \\
\hline Capital Account & 0.2 & 0.2 & 0.2 & 0.3 & 0.2 & 0.2 & 0.2 \\
\hline Financial Account & 11.6 & 4.2 & 3.5 & 6.1 & 5.6 & 5.5 & 6.3 \\
\hline Overall FDI & 4.0 & 3.6 & 2.7 & 3.2 & 3.5 & 3.9 & 4.0 \\
\hline Portfolio investment, net & -0.1 & 0.0 & 0.0 & 0.0 & 0.0 & 0.0 & 0.0 \\
\hline Trade credits, net & 1.5 & 0.0 & 0.4 & 0.7 & 0.1 & 0.1 & 0.1 \\
\hline Loans, net & 7.9 & 1.9 & -0.4 & 1.8 & 2.0 & 1.5 & 2.1 \\
\hline Government and monetary authorities, net & 4.4 & 1.2 & 0.2 & 0.9 & 0.9 & 0.3 & -0.3 \\
\hline Banks, net & 2.2 & 0.4 & -0.4 & 0.2 & 0.4 & 0.6 & 1.8 \\
\hline Other sectors, net & 1.4 & 0.4 & -0.1 & 0.6 & 0.8 & 0.5 & 0.6 \\
\hline Other instruments (excluding arrears), net & -1.7 & -1.3 & 0.7 & 0.3 & 0.0 & 0.0 & 0.0 \\
\hline Errors and omissions & 1.1 & 0.8 & 0.4 & 0.4 & 0.3 & 0.3 & 0.3 \\
\hline Overall balance & 6.1 & -2.3 & -1.3 & 3.1 & 3.2 & 2.7 & 2.8 \\
\hline Financing & -6.1 & 2.3 & -4.1 & -4.6 & -3.2 & -2.7 & -2.8 \\
\hline Reserves ("-" denotes an increase) & -6.2 & 2.2 & -4.1 & -4.6 & -3.2 & -2.7 & -2.8 \\
\hline Other financing items (arrears) & 0.1 & 0.1 & 0.0 & 0.0 & 0.0 & 0.0 & 0.0 \\
\hline Financing gap to be filled from the Fund or other sources & 0.0 & 0.0 & -5.4 & -1.5 & 0.0 & 0.0 & 0.0 \\
\hline
\end{tabular}

Source: Belarus authorities and Fund staff estimations

1/ Assumes an upfront devaluation and the adoption of expenditure-reducing measures. 
Table 5. Belarus: Banking Sector Soundness Indicators, 2004-08

\begin{tabular}{|c|c|c|c|c|c|c|c|}
\hline & 2004 & 2005 & 2006 & 2007 & Mar-08 & Jun-08 & Sep-08 \\
\hline \multicolumn{8}{|l|}{ Capital adequacy } \\
\hline Regulatory capital (in percent of risk-weighted assets) & 25.2 & 26.7 & 24.4 & 19.3 & 17.9 & 17.1 & 16.5 \\
\hline Regulatory Tier I (in percent of risk-weighted assets) & 21.0 & 18.7 & 17.4 & 14.0 & 13.3 & 12.9 & 12.1 \\
\hline Total capital (in percent of total assets) & 19.0 & 19.0 & 17.9 & 16.0 & 14.6 & 13.8 & 13.0 \\
\hline \multicolumn{8}{|l|}{ Asset composition and quality } \\
\hline NPLs (in percent of total loans) & 2.8 & 1.9 & 1.2 & 0.7 & 0.7 & 0.7 & 0.6 \\
\hline Provisions (in percent of NPLs) & 32.4 & 48.4 & 51.3 & 61.5 & 59.1 & 58.7 & 60.9 \\
\hline NPLs net of provisions (in percent of regulatory capital) & 11.4 & 6.3 & 6.1 & 3.8 & 4.2 & 4.2 & 3.7 \\
\hline FX loans (in percent of total loans) & 43.8 & 37.0 & 33.8 & 37.6 & 37.6 & 37.3 & 34.7 \\
\hline $\begin{array}{l}\text { Loans to state-owned enterprises (in percent of total) } 1 / \\
\text { Sectoral distribution of loans (in percent of total) }\end{array}$ & 31.7 & 26.3 & 25.4 & 22.4 & 22.2 & 21.3 & 20.9 \\
\hline Industries & 35.9 & 29.7 & 27.3 & 26.9 & 26.9 & 26.2 & 25.8 \\
\hline Agriculture & 12.6 & 13.4 & 14.6 & 14.4 & 14.8 & 14.7 & 15.3 \\
\hline Trade & 7.2 & 7.3 & 7.7 & 8.1 & 8.8 & 7.8 & 7.7 \\
\hline Construction & 2.1 & 2.0 & 2.2 & 2.7 & 2.7 & 3.1 & 3.6 \\
\hline Households & 21.2 & 26.3 & 27.8 & 27.5 & 27.4 & 27.7 & 28.2 \\
\hline Other & 21.0 & 21.4 & 20.4 & 20.4 & 19.4 & 20.5 & 19.4 \\
\hline \multicolumn{8}{|l|}{ Profitability } \\
\hline Return on assets (after tax) & 1.5 & 1.3 & 1.7 & 1.7 & 1.7 & 1.8 & 1.7 \\
\hline Return on equity (after tax) & 7.8 & 6.8 & 9.6 & 10.7 & 11.3 & 11.9 & 12.0 \\
\hline Interest margin to gross income & 56.2 & 63.0 & 66.2 & 64.1 & 62.1 & 62.0 & 62.1 \\
\hline Noninterest expenses to gross income & 64.2 & 65.1 & 60.9 & 55.3 & 55.4 & 54.8 & 54.4 \\
\hline \multicolumn{8}{|l|}{ Liquidity } \\
\hline Liquid assets to total assets $2 /$ & 27.7 & 30.4 & 24.1 & 22.6 & 24.7 & 21.9 & 20.7 \\
\hline Instant liquidity ratio 3/ & 64.9 & 117.8 & 128.9 & 104.1 & 115.8 & 110.9 & n.a. \\
\hline Current liquidity ratio 4/ & 63.0 & 95.9 & 96.7 & 98.8 & 110.6 & 97.5 & 91.8 \\
\hline Loans to deposits & 123.2 & 119.9 & 135.0 & 144.3 & 147.7 & 152.4 & 165.2 \\
\hline Foreign exchange deposits to total deposits & 46.5 & 38.0 & 34.7 & 38.2 & 39.9 & 38.3 & 37.9 \\
\hline Foreign exchange liabilities to total liabilities & 51.4 & 44.6 & 41.2 & 44.7 & 46.6 & 44.5 & 40.8 \\
\hline \multicolumn{8}{|l|}{ Market risks } \\
\hline Net open position in FX (in percent of capital) & n.a. & 13.1 & 9.5 & 4.8 & n.a. & n.a. & n.a. \\
\hline Share of private securities in total assets & 0.7 & 0.5 & 0.3 & 1.7 & 1.9 & 1.7 & n.a. \\
\hline
\end{tabular}

Sources: National Bank of the Republic of Belarus; and staff estimates.

1/ State-owned enterprises are defined as enterprises with a 100 percent state ownership.

2/ The definition of liquid assets was broadened from 1/1/2004 to include all assets with a remaining maturity of less than 1 month.

3/ Ratio of demand assets to demand liabilities.

4/ Assets/liabilities with a remaining maturity of less than 1 month. 
Table 6. Belarus: Monetary Survey, 2007-2009

(In billions of Belarussian rubels, unless otherwise indicated; end-of-period)

\begin{tabular}{|c|c|c|c|c|c|c|c|}
\hline & $\begin{array}{r}2007 \\
\text { Dec }\end{array}$ & $\begin{array}{c}2008 \\
\text { Nov. }\end{array}$ & $\begin{array}{c}2008 \\
\text { Dec. }\end{array}$ & $\begin{array}{r}2009 \\
\text { Mar }\end{array}$ & $\begin{array}{r}2009 \\
\text { Jun } \\
\end{array}$ & $\begin{array}{r}2009 \\
\text { Sep }\end{array}$ & $\begin{array}{r}2009 \\
\text { Dec } \\
\end{array}$ \\
\hline & & & \multicolumn{5}{|c|}{ Projections } \\
\hline Broad money (M3) & 24,506 & 28,645 & 28,190 & 26,889 & 28,751 & 31,701 & 32,412 \\
\hline Rubel broad money (M2) & 16,770 & 19,244 & 18,602 & 17,824 & 19,151 & 21,134 & 21,753 \\
\hline Currency outside banks & 3,323 & 5,066 & 4,333 & 4,152 & 4,363 & 4,623 & 4,759 \\
\hline Domestic currency deposits & 12,415 & 13,299 & 13,232 & 12,678 & 13,721 & 15,333 & 15,783 \\
\hline Domestic currency securities & 1,032 & 879 & 1,037 & 993 & 1,067 & 1,178 & 1,212 \\
\hline Foreign currency deposits & 7,670 & 9,242 & 9,451 & 8,928 & 9,463 & 10,431 & 10,522 \\
\hline Bank securities in foreign currency & 66 & 159 & 137 & 137 & 137 & 137 & 137 \\
\hline Memo: Total deposits & 20,085 & 22,541 & 22,683 & 21,607 & 23,184 & 25,764 & 26,304 \\
\hline Net Foreign Assets & 6,388 & 5,538 & 3,621 & 5,572 & 4,950 & 4,210 & 4,140 \\
\hline in bln. $\$$ & 2.97 & 2.61 & 1.65 & 2.58 & 2.30 & 1.95 & 1.92 \\
\hline NFA of central bank & 9,056 & 8,770 & 6,960 & 8,147 & 7,875 & 7,529 & 7,529 \\
\hline NFA of DMB & $-2,668$ & $-3,232$ & $-3,339$ & $-2,575$ & $-2,926$ & $-3,319$ & $-3,389$ \\
\hline Net domestic assets & 18,124 & 23,107 & 24,569 & 21,317 & 23,801 & 27,491 & 28,272 \\
\hline Net domestic credit & 25,816 & 21,867 & 38,541 & 35,018 & 37,565 & 41,334 & 42,115 \\
\hline Net credit to general government & $-5,822$ & $-14,613$ & $-10,509$ & $-12,724$ & $-14,004$ & $-14,987$ & $-12,670$ \\
\hline Net credit to central government & $-6,165$ & $-14,973$ & $-10,899$ & $-13,133$ & $-14,433$ & $-15,433$ & $-13,133$ \\
\hline Claims on central government & 4,363 & 4,878 & 6,937 & 6,937 & 6,937 & 6,937 & 6,937 \\
\hline Deposits of the central government & 10,528 & 19,851 & 17,070 & 20,070 & 21,370 & 22,370 & 20,070 \\
\hline Net credit to state and local gov & 343 & $\ldots$ & 390 & 409 & 429 & 446 & 463 \\
\hline Net credit to economy & 31,638 & 36,479 & 49,051 & 47,742 & 51,569 & 56,321 & 54,785 \\
\hline Net credit to public nonfinancial corporn & 7,399 & $\ldots$ & 10,438 & 10,633 & 10,858 & 11,293 & 11,258 \\
\hline Claims on private sector & 24,096 & $\ldots$ & 38,472 & 36,972 & 40,563 & 44,867 & 43,371 \\
\hline Claims on other financial corporations & 143 & $\ldots$ & 141 & 137 & 148 & 162 & 157 \\
\hline Other items, net & $-7,693$ & 1,240 & $-13,973$ & $-13,701$ & $-13,763$ & $-13,843$ & $-13,843$ \\
\hline Capital & $-8,299$ & $\ldots$ & $-14,176$ & $-14,176$ & $-14,176$ & $-14,176$ & $-14,176$ \\
\hline Other net assets & 606 & $\ldots$ & 203 & 475 & 413 & 333 & 333 \\
\hline Other liabilities not included in broad money & 5 & $\ldots$ & $\ldots$ & $\ldots$ & $\ldots$ & $\ldots$ & ... \\
\hline
\end{tabular}

Sources: National Bank of Belarus; and Fund staff estimates. 
Table 7. Belarus: Monetary Authorities' Accounts, 2007-09

(In billions of Belarussian rubels, unless otherwise indicated; end-of-period)

\begin{tabular}{|c|c|c|c|c|c|c|c|}
\hline & $\begin{array}{r}2007 \\
\text { Dec }\end{array}$ & $\begin{array}{r}2008 \\
\text { Nov }\end{array}$ & $\begin{array}{l}2008 \\
\text { Dec. }\end{array}$ & $\begin{array}{r}2009 \\
\text { Mar }\end{array}$ & $\begin{array}{r}2009 \\
\text { Jun }\end{array}$ & $\begin{array}{r}2009 \\
\text { Sep }\end{array}$ & $\begin{array}{r}2009 \\
\text { Dec } \\
\end{array}$ \\
\hline & & \multicolumn{6}{|c|}{ Projections } \\
\hline Reserve money & 6,896 & 7,591 & 6,904 & 6,889 & 7,323 & 7,763 & 7,905 \\
\hline Rubel Reserve money & 6,876 & 7,573 & 6,902 & 6,886 & 7,320 & 7,760 & 7,903 \\
\hline Currency outside banks & 3,323 & 5,066 & 4,333 & 4,152 & 4,363 & 4,623 & 4,759 \\
\hline Required reserves & 1,002 & 2,503 & 1,712 & 1,914 & 2,070 & 2,312 & 2,379 \\
\hline In national currency & 1,002 & & 1,712 & 1,914 & 2,070 & 2,312 & 2,379 \\
\hline Time depos., NBB sec., and depos. of nonbanks & 2,550 & 4 & 856 & 820 & 887 & 826 & 765 \\
\hline Non-Rubel Reserve money & 21 & 18 & 3 & 3 & 3 & 3 & 3 \\
\hline Net Foreign Assets & 9,056 & 8,770 & 6,960 & 8,147 & 7,875 & 7,529 & 7,529 \\
\hline (in bn. \$) & 4.21 & 4.14 & 3.23 & 3.78 & 3.65 & 3.49 & 3.49 \\
\hline Net foreign assets (convertible) & 9,056 & 8,770 & 6,960 & 8,147 & 7,875 & 7,529 & 7,529 \\
\hline (in bn. \$) & 4.21 & 4.14 & 3.23 & 3.78 & 3.65 & 3.49 & 3.49 \\
\hline Foreign assets & 10,361 & 9,706 & 7,913 & 10,825 & 11,469 & 12,039 & 12,955 \\
\hline (in bn. \$) & 4.82 & 4.58 & 3.67 & 5.02 & 5.32 & 5.58 & 6.01 \\
\hline Foreign liabilities & 1,305 & 936 & 953 & 2,677 & 3,594 & 4,510 & 5,426 \\
\hline (in bn. \$) & 0.61 & 0.44 & 0.44 & 1.24 & 1.67 & 2.09 & 2.52 \\
\hline Of which: IMF credit (in bn. \$) & 0.0 & 0.0 & 0.0 & 0.8 & 1.2 & 1.6 & 2.1 \\
\hline Net domestic assets & $-2,159$ & $-1,179$ & -56 & $-1,258$ & -552 & 234 & 376 \\
\hline Net domestic credit & $-1,248$ & -429 & 579 & -895 & -127 & 738 & 881 \\
\hline Net credit to general government & $-4,189$ & $-7,506$ & $-6,624$ & $-9,624$ & $-10,924$ & $-11,924$ & $-9,624$ \\
\hline Net credit to local gov and state entp & 0.0 & -0.5 & 0.1 & 0.1 & 0.1 & 0.1 & 0.1 \\
\hline Net credit to central government & $-4,189$ & $-7,506$ & $-6,624$ & $-9,624$ & $-10,924$ & $-11,924$ & $-9,624$ \\
\hline $\begin{array}{l}\text { Claims on government (loans and gov } \\
\text { securities) }\end{array}$ & 1,652 & 1,598 & 1,597 & 1,597 & 1,597 & 1,597 & 1,597 \\
\hline Deposits of central gov & 5,841 & 9,104 & 8,220 & 11,220 & 12,520 & 13,520 & 11,220 \\
\hline Credit to economy & 2,941 & 7,078 & 7,202 & 8,728 & 10,797 & 12,662 & 10,505 \\
\hline Credit to banks & 1,804 & 5,366 & 5,319 & 6,758 & 8,739 & 10,516 & 8,272 \\
\hline Claims on banks & 1,804 & 5,366 & 5,319 & 6,758 & 8,739 & 10,516 & 8,272 \\
\hline In national currencies & 1,555 & 5,055 & 5,010 & 6,448 & 8,429 & 10,207 & 7,962 \\
\hline In foreign currencies & 250 & 311 & 309 & 309 & 309 & 309 & 309 \\
\hline (in \$ mln.) & 0.12 & 0.15 & 0.14 & 0.14 & 0.14 & 0.14 & 0.14 \\
\hline Credit to non-banks & 1,137 & 1,711 & 1,883 & 1,971 & 2,058 & 2,146 & 2,233 \\
\hline Claims on private sector & 1,107 & $\ldots$ & 1,872 & 1,960 & 2,047 & 2,135 & 2,222 \\
\hline Net credit to non-financial public enterprises & 22 & $\ldots$ & 1 & 1 & 1 & 1 & 1 \\
\hline Net credit to other financial institutions & 8 & & 10 & 10 & 10 & 10 & 10 \\
\hline Other items, net & -911 & -751 & -635 & -363 & -425 & -505 & -505 \\
\hline Valuation effect & -2 & $\ldots$ & -185 & 271 & -62 & -79 & 0 \\
\hline \multicolumn{8}{|l|}{ Memorandum items: } \\
\hline 12-month percent change in rubel broad money & 35 & 15 & 11 & 7 & 0 & 3 & 17 \\
\hline 12-month percent change in reserve money & 38 & 10 & 0 & 1 & -5 & 1 & 14 \\
\hline 12 month percent change in claims on private sector & 51 & $\ldots$ & 60 & 40 & 34 & 27 & 13 \\
\hline 12 month percent change in claims of public enterprises & 36 & 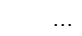 & 41 & 33 & 23 & 15 & 8 \\
\hline Velocity & 5.7 & 6.6 & 6.6 & 6.7 & 6.7 & 6.6 & 6.5 \\
\hline Rubel broad money multiplier & 2.9 & 2.7 & 2.7 & 2.6 & 2.6 & 2.7 & 2.8 \\
\hline Of which: Currency-to-Deposit ratio & 0.20 & 0.26 & 0.30 & 0.30 & 0.30 & 0.28 & 0.28 \\
\hline Real GDP growth (annual) & & $\ldots$ & 8 & 5 & 2 & -1 & 1 \\
\hline End of period CPI inflation (YOY) & 12 & $\ldots$ & 14 & 19 & 16 & 13 & 12 \\
\hline Government deposits with commercial banks & 4,686 & 10,747 & 8,849 & 8,849 & 8,849 & 8,849 & 8,849 \\
\hline
\end{tabular}


Table 8. Belarus: Medium-Term Scenario, 2006-13

(Percent change, unless otherwise indicated)

\begin{tabular}{|c|c|c|c|c|c|c|c|c|}
\hline & \multirow[b]{2}{*}{2006} & \multirow[b]{2}{*}{2007} & \multicolumn{6}{|c|}{ Projections } \\
\hline & & & 2008 & 2009 & 2010 & 2011 & 2012 & 2013 \\
\hline Real GDP & 10.0 & 8.2 & 10.5 & 1.4 & 2.3 & 5.2 & 7.2 & 7.3 \\
\hline Real domestic demand & 13.9 & 12.8 & 14.3 & -2.2 & 1.3 & 4.6 & 8.3 & 8.7 \\
\hline Private Consumption & 13.0 & 13.3 & 14.0 & -1.0 & 1.5 & 5.0 & 9.0 & 9.0 \\
\hline Public Consumption & -0.2 & 0.5 & 1.2 & 0.0 & 1.0 & 1.0 & 1.0 & 1.0 \\
\hline Gross capital formation & 26.2 & 19.5 & 21.4 & -4.9 & 1.0 & 5.6 & 10.3 & 11.3 \\
\hline Exports & 8.2 & 6.7 & 6.2 & 3.2 & 2.2 & 5.6 & 6.0 & 6.1 \\
\hline Imports & 21.6 & 7.3 & 16.2 & -3.1 & 0.5 & 4.5 & 8.0 & 8.7 \\
\hline \multicolumn{9}{|l|}{ Contributions to GDP growth (percent) } \\
\hline Real domestic demand & 14.0 & 13.4 & 15.6 & -2.5 & 1.4 & 5.0 & 8.8 & 9.4 \\
\hline Final consumption & 6.6 & 7.0 & 7.9 & -0.5 & 1.0 & 2.9 & 5.0 & 5.1 \\
\hline Gross capital formation & 7.5 & 6.4 & 7.7 & -1.9 & 0.4 & 2.1 & 3.8 & 4.3 \\
\hline Net exports & -7.9 & -0.8 & -6.9 & 3.9 & 0.9 & 0.3 & -1.7 & -2.1 \\
\hline GDP deflator & 10.7 & 12.1 & 20.2 & 17.1 & 7.1 & 8.7 & 9.1 & 9.1 \\
\hline \multicolumn{9}{|l|}{ Consumer prices } \\
\hline Period average & 7.0 & 8.4 & 14.9 & 15.7 & 6.1 & 7.7 & 7.5 & 7.2 \\
\hline End-period & 6.6 & 12.1 & 13.7 & 11.5 & 8.0 & 7.5 & 7.5 & 7.0 \\
\hline \multicolumn{9}{|l|}{ Nonfinancial public sector (percent of GDP) } \\
\hline Central government balance & 0.4 & -0.6 & -0.8 & 0.0 & -1.0 & -1.3 & -1.4 & -1.5 \\
\hline General government balance & -1.0 & 0.4 & -0.5 & 0.3 & -0.7 & -0.3 & -0.3 & -0.3 \\
\hline \multicolumn{9}{|l|}{ External indicators } \\
\hline Current account (percent of GDP) & -3.9 & -6.8 & -7.6 & -5.4 & -3.6 & -3.0 & -3.3 & -4.0 \\
\hline Trade balance (percent of GDP) & -6.1 & -9.1 & -9.6 & -8.6 & -7.4 & -7.1 & -7.5 & -8.3 \\
\hline Net FDI (percent of GDP) & 0.9 & 4.0 & 3.6 & 2.7 & 3.2 & 3.5 & 3.9 & 4.0 \\
\hline Gross external debt (percent of GDP) & 18.5 & 28.0 & 25.3 & 32.4 & 33.9 & 31.9 & 29.7 & 29.2 \\
\hline Real Effective Exchange Rate (CPI-base & & & & & & & & \\
\hline percent change) & -2.0 & -4.4 & -1.1 & -4.8 & -3.5 & 0.0 & 0.0 & 0.0 \\
\hline Terms of trade shocks, percent of GDP & 1.6 & -2.4 & 3.7 & -1.1 & -0.5 & -0.8 & 0.2 & 0.1 \\
\hline Nominal GDP (trillions of Belarus rubels) & 79 & 96 & 128 & 152 & 166 & 190 & 222 & 260 \\
\hline Nominal GDP (billions of U.S. dollars) & 37 & 45 & 60 & $\ldots$ & $\ldots$ & $\ldots$ & $\ldots$ & $\ldots$ \\
\hline
\end{tabular}

Sources: Belarus authorities; and IMF staff estimates and projections. 
Table 9. Belarus: Main FSAP Update Recommendations

Priority

1. Establish a dedicated agency to receive all guaranteed loans and associated deposits.

2. Strengthen independence of the NBRB Board and bank supervisory processes.

3. Abolish interest rate ceilings on rubel lending to the corporate sector.

4. Revise the loan classification and provisioning requirements to reflect the entire balance of non-performing

\section{Short term}

1. Engage a qualified experienced consultant to assist the Belarusbank privatization working group.

2. Move government deposits from banks to the NBRB.

3. Offer SOE deposits to banks on a competitive basis.

4. Document the framework for emergency liquidity assistance.

5. Abolish the obligatory reinsurance requirement for local insurance companies.

\section{Medium term}

1. Adopt a joint NBRB/MoF crisis management framework and operational guidelines.

2. Make explicit the legal power of the NBRB to suspend dividend payout.

3. Establish legal certainty regarding the outcome of license withdrawal.

4. Provide for a more expedient bankruptcy proceedings.

5. Strengthen resources of the insurance and securities market supervisors.

6. Allow private insurance companies to sell compulsory insurance products.

7. Adopt a framework law establishing an effective securities regulator. 


\section{Appendix Figure I.1. Belarus: External Debt Sustainability: Bound Tests of the} Program Scenario 1/ (External debt in percent of GDP)
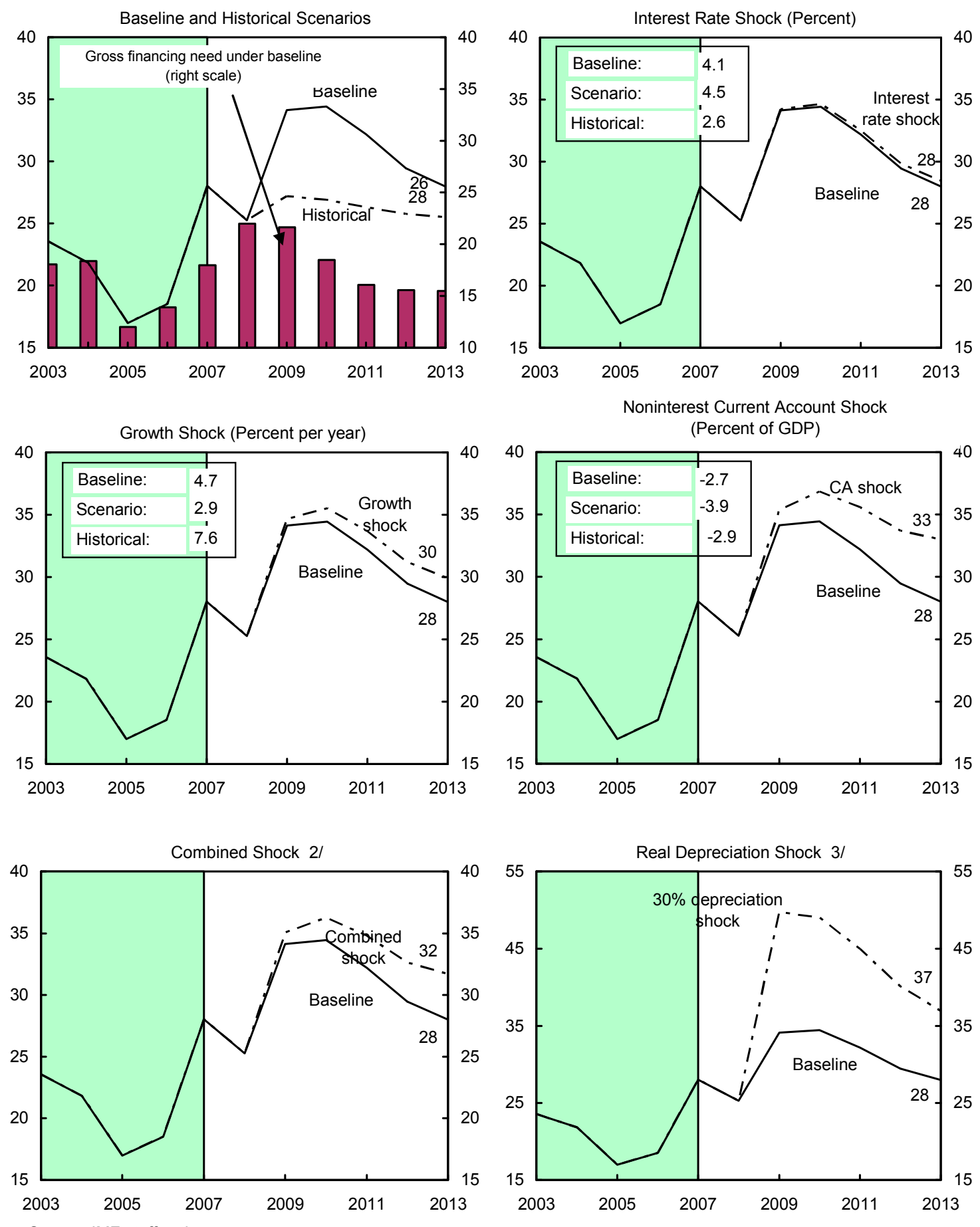

Source: IMF staff estimates.

$1 /$ Shaded areas represent actual data. Individual shocks are permanent one-half standard deviation shocks. Figures in the boxes represent average projections for the respective variables in the baseline and scenario being presented. Ten-year historical average for the variable is also shown.

2/ Permanent $1 / 4$ standard deviation shocks applied to real interest rate, growth rate, and current account balance.

$3 /$ One-time real depreciation of 30 percent occurs in 2008. 
Appendix Table I.1. Belarus: External Debt Sustainability Framework, 2003-13

(Percent of GDP, unless otherwise indicated)

\begin{tabular}{|c|c|c|c|c|c|c|c|c|c|c|c|c|}
\hline & \multicolumn{5}{|c|}{ Actual } & \multicolumn{7}{|c|}{ Projections } \\
\hline & 2003 & 2004 & 2005 & 2006 & 2007 & 2008 & 2009 & 2010 & 2011 & 2012 & 2013 & $\begin{array}{l}\text { Debt-stabilizing } \\
\text { noninterest current } \\
\text { account }\end{array}$ \\
\hline Baseline: external debt & 23.6 & 21.8 & 17.0 & 18.5 & 28.0 & 25.3 & 32.4 & 33.9 & 31.9 & 29.7 & 29.2 & -7.0 \\
\hline Change in external debt & -3.2 & -1.7 & -4.8 & 1.5 & 9.5 & -2.8 & 7.1 & 1.5 & -1.9 & -2.2 & -0.5 & \\
\hline Identified external debt-creating flows $(4+8+9)$ & -3.2 & -0.4 & -7.9 & -0.2 & 0.0 & 2.2 & 2.4 & -0.2 & -1.9 & -2.4 & -1.7 & \\
\hline Current account deficit, excluding interest payments & 2.0 & 4.9 & -1.8 & 3.5 & 6.3 & 6.7 & 4.3 & 2.3 & 1.8 & 2.1 & 2.8 & \\
\hline Deficit in balance of goods and services & 3.7 & 6.6 & -0.7 & 4.1 & 6.3 & 6.7 & 4.5 & 2.5 & 1.9 & 2.1 & 2.7 & \\
\hline Exports & 65.0 & 69.1 & 59.8 & 60.2 & 61.6 & 64.3 & 61.1 & 63.5 & 63.4 & 61.4 & 59.1 & \\
\hline Imports & 68.7 & 75.6 & 59.1 & 64.3 & 67.9 & 71.0 & 65.6 & 66.0 & 65.3 & 63.5 & 61.8 & \\
\hline Net non-debt creating capital inflows (negative) & -0.8 & -0.6 & -1.0 & -1.0 & -3.6 & -3.2 & -2.7 & -3.1 & -3.3 & -3.7 & -3.9 & \\
\hline Automatic debt dynamics $1 /$ & -4.3 & -4.7 & -5.1 & -2.7 & -2.7 & -1.4 & 0.8 & 0.6 & -0.3 & -0.8 & -0.7 & \\
\hline Contribution from nominal interest rate & 0.4 & 0.4 & 0.3 & 0.4 & 0.6 & 0.8 & 1.2 & 1.3 & 1.2 & 1.2 & 1.1 & \\
\hline Contribution from real GDP growth & -1.5 & -2.1 & -1.5 & -1.4 & -1.2 & -2.2 & -0.4 & -0.7 & -1.6 & -2.0 & -1.8 & \\
\hline Contribution from price and exchange rate changes $2 /$ & -3.2 & -3.0 & -3.9 & -1.7 & -2.0 & $\ldots$ & & $\ldots$ & $\ldots$ & $\ldots$ & $\ldots$ & \\
\hline Residual, incl. change in gross foreign assets (2-3) 3/ & 0.0 & -1.3 & 3.0 & 1.7 & 9.5 & -5.0 & 4.8 & 1.7 & -0.1 & 0.2 & 1.2 & \\
\hline External debt-to-exports ratio (percent) & 36.3 & 31.6 & 28.4 & 30.8 & 45.5 & 39.3 & 53.0 & 53.4 & 50.4 & 48.4 & 49.4 & \\
\hline Gross external financing need (billions of U.S. dollars) 4 / & 3.2 & 4.2 & 3.6 & 5.1 & 8.1 & 13.1 & 12.4 & 11.5 & 12.1 & 14.0 & 16.9 & \\
\hline Percent of GDP & 18.0 & 18.4 & 12.0 & 13.9 & 18.0 & 22.0 & 21.6 & 18.4 & 16.9 & 16.7 & 17.2 & \\
\hline Scenario with key variables at their historical averages $5 /$ & & & & & & 25.3 & 25.8 & 26.5 & 26.1 & 25.9 & 26.3 & -5.1 \\
\hline \multicolumn{13}{|l|}{ Key Macroeconomic Assumptions Underlying Baseline } \\
\hline Real GDP growth (percent) & 7.0 & 11.4 & 9.4 & 10.0 & 8.2 & 10.5 & 1.4 & 2.3 & 5.2 & 7.2 & 7.3 & \\
\hline GDP deflator in U.S. dollars (percent change) & 13.6 & 14.4 & 21.5 & 11.2 & 12.0 & 20.8 & -5.6 & 7.1 & 8.7 & 9.1 & 9.1 & \\
\hline Nominal external interest rate (percent) & 1.9 & 1.9 & 2.0 & 2.7 & 3.8 & 3.9 & 4.4 & 4.4 & 4.1 & 4.3 & 4.4 & \\
\hline Growth of exports (U.S. dollar terms, percent) & 24.4 & 35.5 & 15.2 & 23.1 & 24.0 & 39.4 & -9.1 & 13.9 & 14.2 & 13.3 & 12.5 & \\
\hline Growth of imports (U.S. dollar terms, percent) & 25.0 & 40.4 & 3.9 & 33.1 & 28.0 & 39.6 & -11.6 & 10.2 & 13.1 & 13.8 & 13.9 & \\
\hline Current account balance, excluding interest payments & -2.0 & -4.9 & 1.8 & -3.5 & -6.3 & -6.7 & -4.3 & -2.3 & -1.8 & -2.1 & -2.8 & \\
\hline Net nondebt creating capital inflows & 0.8 & 0.6 & 1.0 & 1.0 & 3.6 & 3.2 & 2.7 & 3.1 & 3.3 & 3.7 & 3.9 & \\
\hline
\end{tabular}

1/ Derived as $[r-g-\rho(1+g)+\varepsilon \alpha(1+r)](1+g+\rho+g \rho)$ times previous period debt stock, with $r=$ nominal effective interest rate on external debt; $\rho=$ change in domestic GDP deflator in U.S. dollar terms, $g=$ real GNP growth rate, $e=$ nominal appreciation (increase in dollar value of domestic currency), and $a=$ share of domestic-currency denominated debt in total external debt.

$2 /$ The contribution from price and exchange rate changes is defined as $[-\rho(1+g)+\varepsilon \alpha(1+r)] /(1+g+\rho+g \rho)$ times previous period debt stock. $\rho$ increases with an appreciating domestic currency $(\varepsilon>0)$ and rising inflation (based on GDP deflator).

3/ For projection, line includes the impact of price and exchange rate changes.

4/ Defined as current account deficit, plus amortization on medium- and long-term debt, plus short-term debt at end of previous period. Differs slightly from external financing requirement in Staff Report because includes official transfers and IMF re

5/ The key variables include real GNP growth; nominal interest rate; dollar deflator growth; and both non-interest current account and non-debt inflows in percent of GNP. 


\section{Appendix Figure I.2. Belarus: Public Debt Sustainability: Bound Tests of Program Scenario 1/ (Public debt in percent of GDP)}
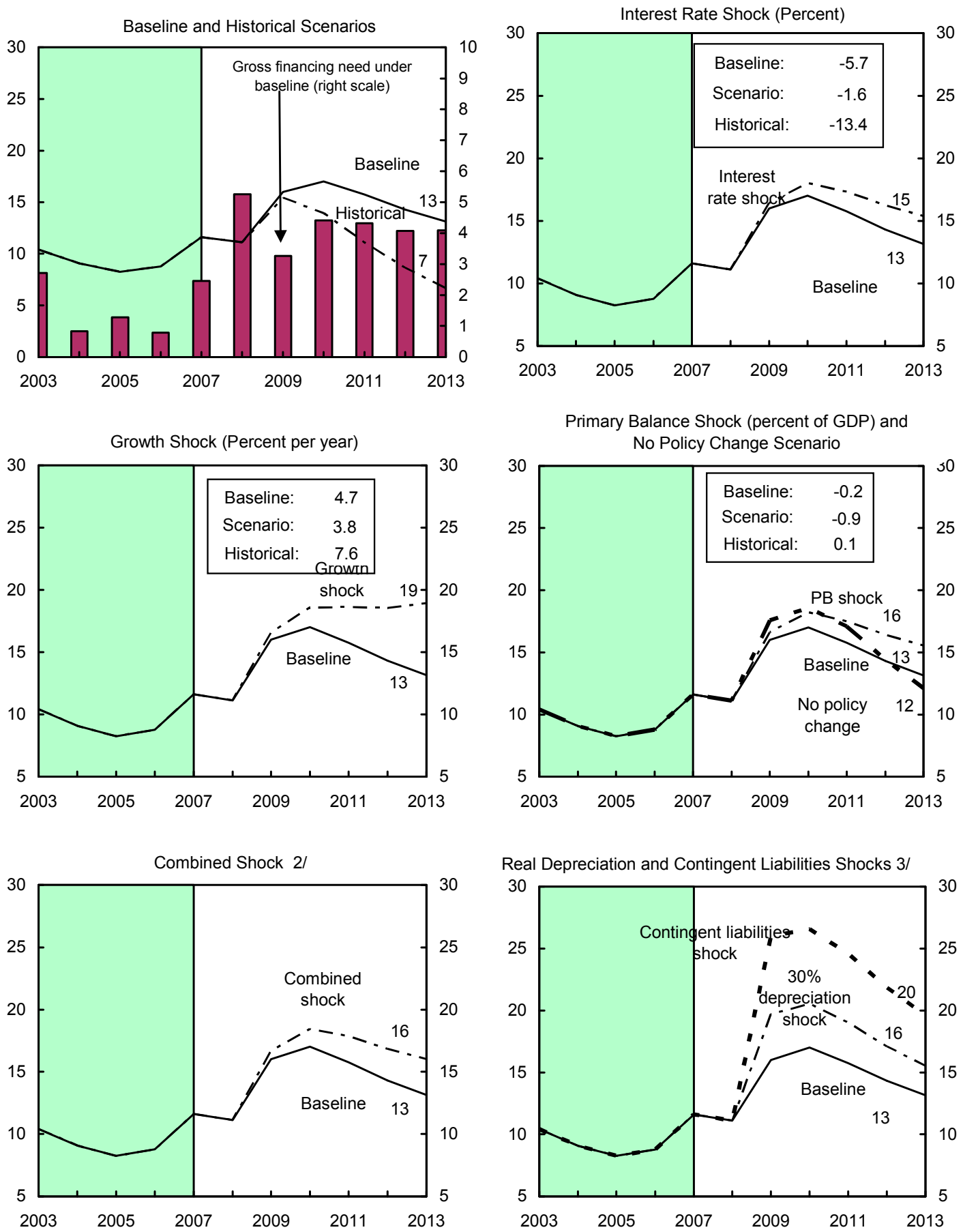

Sources: IMF staff estimates.

$1 /$ Shaded areas represent actual data. Individual shocks are permanent one-half standard deviation shocks. Figures in the boxes represent average projections for the respective variables in the baseline and scenario being presented. Ten-year historical average for the variable is also shown.

2/ Permanent $1 / 4$ standard deviation shocks applied to real interest rate, growth rate, and primary balance.

$3 /$ One-time real depreciation of 30 percent and 10 percent of GDP shock to contingent liabilities occur in 2009, with real depreciation defined as nominal depreciation (measured by percentage fall in dollar value of local currency) minus domestic inflation (based on GDP deflator). 
Appendix Table I.2. Belarus: Public Sector Debt Sustainability Framework, 2003-13

(Percent of GDP, unless otherwise indicated)

\begin{tabular}{|c|c|c|c|c|c|c|c|c|c|c|c|c|}
\hline & \multicolumn{5}{|c|}{ Actual } & \multicolumn{6}{|c|}{ Projections } & \multirow{2}{*}{$\begin{array}{l}\text { Debt-stabilizing } \\
\text { primary balance } 9 /\end{array}$} \\
\hline & 2003 & 2004 & 2005 & 2006 & 2007 & 2008 & 2009 & 2010 & 2011 & 2012 & 2013 & \\
\hline $\begin{array}{l}1 \text { Baseline: public sector debt } 1 / \\
\text { Of which: foreign-currency denominated }\end{array}$ & $\begin{array}{r}10.4 \\
6.0\end{array}$ & $\begin{array}{l}9.1 \\
3.6\end{array}$ & $\begin{array}{l}8.3 \\
2.6\end{array}$ & $\begin{array}{l}8.8 \\
2.3\end{array}$ & $\begin{array}{r}11.6 \\
6.6\end{array}$ & $\begin{array}{r}11.1 \\
6.1\end{array}$ & $\begin{array}{l}16.0 \\
11.8\end{array}$ & $\begin{array}{l}17.0 \\
13.1\end{array}$ & $\begin{array}{l}15.8 \\
12.4\end{array}$ & $\begin{array}{l}14.3 \\
11.4\end{array}$ & $\begin{array}{l}13.2 \\
10.7\end{array}$ & -0.9 \\
\hline 2 Change in public sector debt & -1.2 & -1.3 & -0.8 & 0.5 & 2.8 & -0.5 & 4.9 & 1.0 & -1.2 & -1.5 & -1.2 & \\
\hline 3 Identified debt-creating flows $(4+7+12)$ & 0.7 & -1.5 & -0.5 & -3.2 & 0.7 & 0.2 & -0.8 & 0.8 & 0.1 & -0.2 & 0.2 & \\
\hline 4 Primary deficit & 1.3 & -0.5 & 0.3 & -1.8 & -0.8 & -0.2 & -1.4 & 0.0 & 0.2 & 1.1 & 1.2 & \\
\hline $5 \quad$ Revenue and grants & 45.9 & 46.0 & 47.4 & 49.1 & 50.0 & 52.2 & 48.9 & 48.5 & 47.5 & 46.4 & 45.8 & \\
\hline $6 \quad$ Primary (noninterest) expenditure & 47.2 & 45.5 & 47.7 & 47.3 & 49.2 & 52.0 & 47.5 & 48.5 & 47.7 & 47.5 & 47.0 & \\
\hline 7 Automatic debt dynamics $2 /$ & -2.1 & -2.1 & -1.9 & -1.1 & -1.1 & -2.2 & -0.6 & -0.7 & -1.3 & -2.3 & -2.1 & \\
\hline 8 Contribution from interest rate/growth differential $3 /$ & -2.9 & -2.2 & -1.9 & -1.1 & -1.1 & -2.2 & -0.6 & -0.7 & -1.3 & -2.3 & -2.1 & \\
\hline Of which: contribution from real interest rate & -2.3 & -1.3 & -1.2 & -0.4 & -0.5 & -1.3 & -0.5 & -0.4 & -0.5 & -1.3 & -1.2 & \\
\hline Of which: contribution from real GDP growth & -0.6 & -0.9 & -0.6 & -0.7 & -0.6 & -0.9 & -0.1 & -0.3 & -0.8 & -1.0 & -0.9 & \\
\hline Contribution from exchange rate depreciation $4 /$ & 0.7 & 0.0 & 0.0 & 0.0 & 0.0 & $\ldots$ & $\ldots$ & $\ldots$ & $\ldots$ & $\ldots$ & $\ldots$ & \\
\hline 12 Other identified debt-creating flows & 1.6 & 1.1 & 1.1 & -0.2 & 2.7 & 2.6 & 1.2 & 1.4 & 1.2 & 1.0 & 1.0 & \\
\hline $13 \quad$ Privatization receipts (negative) & 0.1 & 0.1 & 0.1 & -1.2 & 2.0 & 1.0 & 1.2 & 0.4 & 0.2 & 0.0 & 0.0 & \\
\hline Recognition of implicit or contingent liabilities & 0.0 & 0.0 & 0.0 & 0.0 & 0.0 & 0.0 & 0.0 & 0.0 & 0.0 & 0.0 & 0.0 & \\
\hline Other (specify, e.g. bank recapitalization) & 1.5 & 1.1 & 1.1 & 1.0 & 0.7 & 1.6 & 0.0 & 1.0 & 1.0 & 1.0 & 1.0 & \\
\hline 16 Residual, including asset changes (2-3) $5 /$ & -1.9 & 0.2 & -0.4 & 3.7 & 2.1 & -0.7 & 5.7 & 0.3 & -1.4 & -1.3 & -1.3 & \\
\hline Public sector debt-to-revenue ratio $1 /$ & 22.7 & 19.7 & 17.4 & 17.9 & 23.2 & 21.3 & 32.7 & 35.1 & 33.2 & 30.8 & 28.7 & \\
\hline $\begin{array}{l}\text { Gross financing need } 6 / \\
\text { Billions of U.S. dollars }\end{array}$ & $\begin{array}{l}2.7 \\
0.5\end{array}$ & $\begin{array}{l}0.8 \\
0.2\end{array}$ & $\begin{array}{l}1.3 \\
0.4\end{array}$ & $\begin{array}{l}0.8 \\
0.3\end{array}$ & $\begin{array}{l}2.5 \\
1.1\end{array}$ & $\begin{array}{l}5.3 \\
3.1\end{array}$ & $\begin{array}{l}3.3 \\
1.9\end{array}$ & $\begin{array}{l}4.4 \\
2.8\end{array}$ & $\begin{array}{l}4.3 \\
3.1\end{array}$ & $\begin{array}{l}4.1 \\
3.4\end{array}$ & $\begin{array}{l}4.1 \\
4.0\end{array}$ & \\
\hline Scenario with key variables at their historical averages $7 /$ & & & & & & 11.1 & 15.4 & 13.9 & 11.1 & 8.7 & 6.7 & -0.2 \\
\hline Scenario with no policy change (constant primary balance) in $2008-13$ & & & & & & 11.1 & 17.6 & 18.6 & 17.1 & 14.4 & 12.1 & -0.8 \\
\hline \multicolumn{13}{|l|}{ Key Macroeconomic and Fiscal Assumptions Underlying Baseline } \\
\hline Real GDP growth (percent) & 7.0 & 11.4 & 9.4 & 10.0 & 8.2 & 10.5 & 1.4 & 2.3 & 5.2 & 7.2 & 7.3 & \\
\hline Average nominal interest rate on public debt (percent) $8 /$ & 5.3 & 6.4 & 5.2 & 5.5 & 5.6 & 7.3 & 12.2 & 4.7 & 5.6 & 0.0 & 0.0 & \\
\hline Average real interest rate (nominal rate minus change in GDP deflator, percent) & -25.4 & -14.0 & -16.0 & -5.3 & -6.5 & -12.9 & -4.8 & -2.4 & -3.1 & -9.1 & -9.1 & \\
\hline Nominal appreciation (increase in U.S. dollar value of local currency, percent) & -10.9 & -0.6 & 0.8 & 0.6 & -0.5 & $\ldots$ & $\ldots$ & $\ldots$ & $\ldots$ & $\ldots$ & $\ldots$ & \\
\hline Inflation rate (GDP deflator, percent) & 30.7 & 20.4 & 21.2 & 10.7 & 12.1 & 20.2 & 17.1 & 7.1 & 8.7 & 9.1 & 9.1 & \\
\hline Growth of real primary spending (deflated by GDP deflator, percent) & 14.7 & 7.5 & 14.9 & 9.1 & 12.5 & 17.1 & -7.4 & 4.6 & 3.4 & 6.8 & 6.2 & \\
\hline Primary deficit & 1.3 & -0.5 & 0.3 & -1.8 & -0.8 & -0.2 & -1.4 & 0.0 & 0.2 & 1.1 & 1.2 & \\
\hline
\end{tabular}

1/ Gross debt of general government (including guarantees) and of monetary authorities.

2/ Derived as $[(r-\cong(1+g \cong-g+\cong \nexists(1+r \exists /(1+g+\cong+g \cong))$ times previous period debt ratio, with $r=$ interest rate; $\cong=$ growth rate of GDP deflator; $g=$ real GDP growth rate; $\cong=$ share of foreign-currency

denominated debt; and $\cong=$ nominal exchange rate depreciation (measured by increase in local currency value of U.S. dollar).

$3 /$ The real interest rate contribution is derived from the denominator in footnote $2 /$ as $r-\pi(1+g)$ and the real growth contribution as $-\mathrm{g}$.

$4 /$ The exchange rate contribution is derived from the numerator in footnote $2 /$ as $\cong *(1+r)$.

$5 /$ For projections, this line includes exchange rate changes.

6/ Defined as public sector deficit, plus amortization of medium and long-term public sector debt, plus short-term debt at end of previous period.

7/ The key variables include real GDP growth; real interest rate; and primary balance in percent of GDP.

8/ Derived as nominal interest expenditure divided by previous period debt stock.

9/ Assumes that key variables (real GDP growth, real interest rate, and other identified debt-creating flows) remain at the level of the last projection year. 
Mr. Dominique Strauss-Kahn

Managing Director

International Monetary Fund

Washington, DC 20431 U.S.A.

Dear Mr. Strauss-Kahn:

The attached Memorandum of Economic and Financial Policies (MEFP) describes the economic policies and objectives of the authorities of the Republic of Belarus for the remainder of 2008 and for 2009-10. Based on our balance of payments needs and our policies as set in the MEFP, we request the approval of a Stand-By Arrangement (SBA) in an amount of SDR 1,618.118 million (418.77 percent of our quota, equivalent to US\$2.5 billion) for the period January 2009 through March 2010. We believe that the policies described in the MEFP will help us adjust in an orderly manner to the external shocks we now face, and eliminate existing vulnerabilities. Structural challenges in our economy would, nevertheless, remain to be addressed further, and we might consider a follow-up Extended Fund Facility (EFF) arrangement to support these efforts.

The program will be monitored through regular reviews, prior actions, quantitative performance criteria and indicative targets, and structural performance criteria and structural benchmarks. The first purchase of SDR 517.798 million will become available on approval of the program by the Executive Board, the second purchase of SDR 275.08 million on or after May 15, 2009, conditional on the observance of end-March performance criteria and completion of the first review, and the third purchase of SDR 275.08 million on or after August 15, 2009 conditional on observance of the end-June performance criteria and completion of the second review of the program. The full schedule of phasing of purchases under the arrangement and program reviews is set out in Table 1 of this memorandum; the quantitative targets for end-March 2009, end-June 2009, end-September 2009 and endDecember 2009, and continuous performance criteria are set out in Table 2; and the prior actions, structural performance criteria and structural benchmarks are set out in Table 3 . The understandings between the Belarusian authorities and IMF staff regarding the quantitative performance criteria and the structural measures described in this memorandum are further specified in the Technical Memorandum attached to this memorandum.

In addition to the policies outlined in this MEFP, the government stands ready to take additional policy measures as appropriate to ensure the attainment of the program's objectives. We will consult with the Fund on adoption of new measures, and in advance of revisions to the policies contained in this memorandum in accordance of the Fund's policies on such consultations, and provide the Fund with the information it requests for monitoring progress during program implementation. We will also consult with the Fund on our economic policies after the expiration of the arrangement, in line with the Fund's policies on such consultations. 
In continuing with our policy of transparency, we consent to the publication of this letter, the attached MEFP, and the accompanying Executive Board documents on the IMF's website.

Yours sincerely,

$$
\text { /s/ }
$$

S. S. Sidorsky

Prime Minister

of the Republic of Belarus /s/

P. P. Prokopovich

Governor of the National Bank

of the Republic of Belarus 


\section{BeLARUS-Memorandum Of Economic and Financial Policies}

\section{BACKGROUND}

1. The Republic of Belarus has been developing a socially-oriented, market-based economic model, with a view to raising the welfare of the population through rapid GDP growth and economic reforms. Since 2002, GDP growth has averaged close to 9 percent, reflecting strong improvements in labor productivity, reductions in energy intensity, and a high level of investment. Moreover, our economy benefited from favorable developments in the terms of trade, as well as strong growth of the global economy. Prudently managed public finances, on the back of strong growth performance, have allowed us to keep Belarus' foreign and public debt ratios among the lowest in the region, while social spending and indicators of social well being have been maintained at a high level.

2. However, the recent weakening of global activity has created significant challenges for Belarus. Prices for our commodity exports have fallen, and demand for our products is dropping off (as growth in our trading partners slows down). The problem has been exacerbated by delays in export payments. Lingering effects of past booming demand in Belarus and the rapid appreciation of the U.S. dollar, to which we peg our currency, will put further pressure on our trade balance. At the same time, we, like most other countries, are facing much less accessible and more expensive credit markets. We have handled this tension to date by using our currency reserves, but this can be only a temporary response, since we need to raise our reserves to a safer level (and had been doing so through August).

3. We expect that the less favorable external environment will continue into 200910, creating a need for adjustment. With overall growth in the region slowing, we will face continued weak demand for our exports, adversely affecting both their volumes and prices. These developments will be further aggravated by an increase in the gas import price in 2009, in line with agreements reached with Russia in 2007. Notwithstanding our efforts to liberalize the economy and attract larger FDI inflows, we do not expect a rapid improvement in our access to foreign financing on market terms in 2009, owing to the global crisis. Thus, exceptional financing needs in the period ahead are large. We intend to implement strong adjustment measures under our program and pursue available financing from private sector and official sources, but we still expect to face a financing gap of $\$ 4$ billion in the period through 2010. Taking into account the just signed loan agreement with the Russian Federation providing $\$ 1$ billion next year, a residual gap of about $\$ 3$ billion remains.

\section{Program ObJectives}

4. Our program, for which we are seeking assistance, aims at minimizing the impact of the unfavorable external factors, adjusting our economy to the new environment, and reducing vulnerability to future external shocks. This will be accomplished both via upfront actions targeted to solving our most immediate challenges, and aggregate demand management measures to address current account imbalances (combined with adequate safety net measures to protect the most vulnerable). To guard 
against future risk, actions will be taken to increase the NBRB's level of international reserves, reduce the rigidity in our exchange rate arrangement, ensure the stability of the financial sector, and introduce more appropriate wage targets.

5. In line with projected developments in the rest of Eastern Europe, we expect our economy to slow in 2009. In setting our program we have made conservative assumptions about prospects for external finance. To help contain the external current account deficit at a level that can be financed, our demand growth will need to slow substantially. For this reason, moderation of the growth of wages and investment is unavoidable. We expect improved competitiveness to partially compensate for lower demand, with the net result being modest growth of about 1-2 percent and a sharp drop in the current account deficit, to $5 \frac{1}{2}$ percent of GDP. Inflation will gradually come down from existing levels, and we expect it to drop to $11 \frac{1}{2}$ percent by end-2009. We are working to secure additional financing and with this in place, or if external shocks prove milder than projected, our growth prospects could be better.

\section{We expect the economy to rebound in the medium term as the effects of the} global shocks on the region wane, but are prepared to respond flexibly to economic developments. Growth should return close to potential by 2011, and inflation to single digits by late 2010 . We anticipate moderate current account deficits, and with capital inflows improving in 2010, we expect significant reserve accumulation. However, we also believe that the implementation of our structural policies (discussed below), including reductions in the tax burden, accelerated privatization, and price liberalization, will create significant upside growth potential, and could help us attract additional external financing. In this event, we would target faster reserve accumulation, and might also consider a less restrictive fiscal stance. The macroeconomic program and policy measures for 2010 will be initiated during the second review.

\section{POLICIES FOR 2009}

\section{A. Monetary and Exchange Rate Policies}

\section{Implementing a more robust exchange rate regime is a cornerstone of our}

program. We will continue to use the exchange rate as a nominal anchor, but will shift our peg to a basket of currencies, and apply a wider band ( \pm 5 percent) around the basket parity. We intend to use the band in a flexible manner, including allowing the exchange rate to weaken relative to the central rate if meeting the target on the accumulation of net international reserves (NIR) is at risk. Our basket will comprise of the US dollar, the euro and the Russian ruble with a weight of one-third each, and we expect the new parity will be consistent with our economic fundamentals (setting up this new regime is a prior action for our program). This new regime will help us cope with shocks in a challenging external environment. 
8. Monetary policy will stand ready to support the new currency band, and be set consistent with our CPI inflation target of 11/2 percent for end-2009. Consistent with both of these goals, we will keep NBRB interest rates positive in real terms. We will adjust the refinancing rate and our other policy rates regularly based on updated inflation projections. To better transmit our policy to lending rates (and encourage better risk management by banks), we will abolish the interest rate ceiling on ruble loans by banks to the corporate sector (prior action). We will adapt the monetary guidelines for the NBRB to reflect our policy intentions, in particular our indicative base money target (which has been calculated in line with projected nominal income, but assuming a small velocity increase). Our floor for net international reserves and ceiling for net domestic assets of the NBRB will be quantitative performance criteria under the program.

\section{B. Financial Sector Policies}

\section{We have already taken a range of measures aimed at maintaining financial system stability, and these have been effective to date, but we see a need for several refinements:}

- $\quad$ To further strengthen depositors' faith in banks, on November 4, 2008, the President signed Decree No. 22 extending a full guarantee to household deposits effective immediately. Moreover, the recently passed law on deposit insurance (effective from January 1, 2009) establishes a strengthened framework under which the new Agency for Deposit Insurance is able to provide a more equitable treatment of banks and a fixed timeline for compensation of deposits in case of bank closure.

- We recognize that uncollateralized liquidity support to banks must remain truly exceptional, and that once the current pressures abate, such liquidity support will generally be provided against good quality collateral. Furthermore, to ensure that liquidity support to banks is appropriately limited and does not unintentionally evolve into financing for insolvent institutions, the NBRB will apply strengthened monitoring and supervision to those banks using the new uncollateralized lending facility, or any other exceptional form of financing. In particular, banks using the facility over an extended period will be subject to more frequent on-site inspections and some restrictions on their activities (for instance, bank-specific prudential norms).

- $\quad$ To ensure adequate capitalization of state banks, we have allocated additional budget resources in the amount of 3 trillion rubels to their equity funds. At present we have no plans to recapitalize any banks in 2009. The foreign banks operating in Belarus have all confirmed their commitment to remain well capitalized to finance their expected lending in 2009. Should capitalization issues arise in private banks we will use our existing framework, including negotiations with shareholders, liquidation and nationalization (supported by government resources), as appropriate, to rapidly resolve the issues. 
- We intend to formalize the institutional framework for dealing with a potential financial crisis. We will adopt and implement a memorandum of understanding between the Ministry of Finance, the Ministry of Economy, the NBRB, and the new Agency for Deposit Insurance. This will define the roles and powers of various authorities, as well as practical guidelines for coordination and information exchange.

- In accordance with the recommendations of the FSAP mission, we will by endSeptember 2009 bring our loan classification and provisioning requirements in line with the best international practices, possibly using MCM TA for this purpose (structural benchmark). In addition, we will introduce a requirement for banks to form reserves on loans classified in group I ( 0.5 percent of these loans). ${ }^{7}$

10. The key pillar of our financial sector agenda is the transfer of directed lending programs to the budget. This will stimulate banks to update their credit risk assessment and management practices. Specifically, we intend to:

- $\quad$ Amend the relevant legislation ${ }^{8}$ to prohibit the central and local governments from making any additional transfers to its deposit accounts with the commercial banks, either short or long term (prior action). The existing stock of these deposits will be transferred back to the NBRB accounts in line with the schedule for repayment of the corresponding loans. All funding to the only two projects remaining in force, "On Construction of Dairy Farms" (Presidential Decree Number 332 dated June 13, 2008) and "On Certain Issues of the Bellegprom Concern" (Presidential Decree 282 dated May 19, 2008) that had not been fully disbursed, has been discontinued as of December 19, 2008. Funding to these projects will only resume once they have been brought back on to the budget. We will not approve any new directed lending programs financed with budget deposits (structural benchmark).

- $\quad$ The NBRB will gradually disengage from direct lending to other sectors of the economy (non-financial organizations). In 2009, we will limit the growth of such loans to 350 billion rubels. Starting in 2010 the NBRB will stop extending new loans to non-financial organizations.

11. We will also begin the process of privatizing the large state-owned banks. We are looking for a strategic investor to sell the majority shareholding in two state banks (OJSC Belpromstroibank and OJSC Belinvestbank) and a minority holding in JSSB Belarusbank and OJSC Belagroprombank as soon as market conditions permit. By end-August 2009 we

\footnotetext{
${ }^{7}$ There are five groups of loans. Group I consists of good quality or standard loans.

${ }^{8}$ Agreement \#447/D of November 28, 2006 On the Investment of Deposits In Belarusian Rubel at the NBRB by the Ministry of Finance of the Republic of Belarus.
} 
will engage a qualified, experienced, and reputable consultant, on a competitive basis, to assist us in preparing state-owned banks for partial or full privatization (structural benchmark). The objective will be to attract strategic investors capable of know-how and technology transfer, as well as reliable funding support.

\section{Fiscal Policy}

12. We intend to target a balanced central government budget in both 2008 and 2009, excluding bank recapitalization operations (up to minimum regulatory norms). The 2009 budget will be based on prudent macroeconomic assumptions. Taking into account the discontinuation of directed lending through banks in 2009 overall state funding will be reduced compared to 2008 by 3 percent of GDP. Moreover, some of our adjustment measures would apply to the full public sector, leading to a much stronger adjustment and thus a much firmer assurance that economy-wide consumption and investment can be restrained in line with our external financing constraint. As a prior action, we have approved a zero budget target of the central government for 2009 by presidential decree. In line with legislative procedures, which provide ample time for consultations on priorities within the government and with the legislative branch, ${ }^{9}$ we will approve a revised 2009 budget, in line with the program's objectives, by end-June 2009. The fiscal performance will be monitored by a quantitative performance criterion. We understand the need in the first half of the year to execute the budget very cautiously. As discussed below, if economic conditions permit, the budget targets for end-September and end-December would be adjusted to allow a higher deficit if more financing than programmed were to materialize.

\section{Our key initiatives to meet our 2009 budget target include:}

- $\quad$ Prudent public sector wage growth. As a prior action, on November 29, 2008, the Government of the Republic of Belarus adopted Resolution No 1818, in accordance with which the $1^{\text {st }}$ grade wage has been reduced from 91,000 rubels to 77,000 rubels. A similar decision on wages for state and military servants has been adopted by the Presidential Decree No 654, dated November 28, 2008. These decisions have above that prevailing in October. We will consider a further 5 percent increase in the $1^{\text {st }}$ grade wage in May 2009, economic conditions permitting. Assessment of these conditions and the feasibility of an increase will be a focus for the first review. Wage setting in state enterprises will also be based on the need to contribute to improving the economy's competitiveness. For that purpose, by end-January 2009 the Ministry of Economy, the Ministry of Finance, and the Ministry of Labor, in line with the

\footnotetext{
${ }^{9}$ In the normal budget preparation process, the government gets one month to approve the draft budget, the President then has another month to offer corrections and adjustments, before submission to the Parliament, which has two months to adopt the budget. Finally, one more month is provided for its approval by the Council of the Republic and its signature into law by the President.
} 
established practice will approve a decree that will limit growth of wages in companies that are fully state owned, or in which the government has a dominant influence, a majority, or a blocking shareholder position, to 5 percent in nominal terms in 2009. We are confident that this measure will cover about 80 percent of all employees in the Republic of Belarus.

- A pause in growth of capital expenditure. For several years, we have had one of the highest rates of public investment in the region, and can afford to pause. In 2009 we intend to reduce central government capital expenditures relative to 2008, while maintaining our public investment rate above our peers. We will also take steps to contain state enterprise investment, and in the context of less favorable financing environment avoid payment arrears. Against this background, to the extent higher financing materializes, it would be a priority for us to restore some growth in investment. In particular, we will spend 50 percent of foreign-financed project resources in excess of program projections. Additional resources from international financial institutions will be exempt from this limit.

- Increases in utility tariffs. Our communal service tariffs have not kept pace with rising input costs, and we need to correct this, given the fiscal burden. The tariffs charged to households (average payment for an apartment, including heating), currently equal to 141,862 rubels, will be raised to 162,865 rubels by January 1, 2009, and possibly increased further during the year. Additional increases will be implemented in 2010, to improve the cost recovery ratio.

\section{Targeted social spending will be increased to protect the most vulnerable from} adjustment measures. While Belarus has a developed an institutional framework that provides an extensive safety net, we will consult with the World Bank about additional measures in the context of possibly higher unemployment. Regarding the effects of the energy price increases, until a better targeted assistance is developed, we will implement a limited social tariff scheme.

\section{We will continue to seek additional external financing for the budget, with a} view to countering downward pressures on growth via fiscal stimulus later in 2009 . We are aiming to accelerate our program of privatization, with a focus on large scale enterprises.

16. Our list ${ }^{10}$ contains 147 corporations, including in the telecommunications, chemical, petrochemical, and construction industries, the shares of which the government will sell. We will also pursue additional official loans. To the extent that we can secure additional financing, we intend to save at a minimum 50 percent of the excess (adding to our international reserves). If economic conditions permit, the remainder would be used towards

\footnotetext{
${ }^{10}$ Approved by Resolution \#1021 of the Council of Ministers of the Republic of Belarus dated July $14,2008$.
} 
higher productive spending, in particular to lift investment towards 2008 levels, to a limit of a 1.8 percent of GDP central government deficit. Our fiscal targets for the second half of 2009 would be adjusted to accommodate such increased spending. More generally, given our strong public finances, we will keep fiscal targets as a focus for each review, to account for macroeconomic and financing developments.

\section{We intend to establish an agency that would facilitate leasing equipment for our} exporters. The modalities to do so, including the fiscal treatment of expenditures will be discussed during the first review. However, we recognize that the proper treatment of expenditures by this agency may entail its recognition as spending under the central government budget. Moreover, for the purpose of the Memorandum, we intend to treat capital injections into entities outside the general government as expenditure on the general government's budget.

\section{Policies to Improve the Business Climate}

18. We are aware that our wage and price controls and targets, while providing for short-term stability, create significant inefficiencies and even vulnerabilities. The rigidities that they introduce undermine the efficient adaptation of the economy to shocks. To address this issue, we have already adopted measures in 2008, and are planning additional measures for 2009 that will reduce price controls. Our present macroeconomic stabilization challenge precludes a rapid liberalization - pent up forces could overwhelm the benefits of faster adaptation — but we consider a credible phase out over 2009-11 to be an important contribution to confidence in our macroeconomic framework. To this end we envision:

- We will no longer announce medium-term dollar wage targets - which threaten competitiveness and the viability of our exchange rate regime.

- We will not extend the regulatory act imposing a general ceiling on monthly prices increases of $1 / 2$ percent beyond March 2009 (structural benchmark).

- $\quad$ Over time, we will reduce the number of products considered subject to additional price controls under current legislation.

- $\quad$ And in 2010, after the economy has adjusted to its shocks, we will take the necessary legal steps to stop the application of mandatory wage policy to companies in which the government does not have majority control.

19. We are also determined to increase the scope for private sector activity, open the economy to FDI, and improve the business climate. We are in the process of implementing a comprehensive plan for both creating a favorable investment and business climate and putting in place mechanisms and instruments needed for the private sector to develop. In particular, we intend to create an attractive environment for foreign investment. Our most important plans in this area, which could allow us to rank among the 30 most leading countries from the point of view of conditions for creating and doing business, include: 
- A reduction in the size of the general government and the tax burden, including by halving the turnover tax in 2009, and reducing the local sales tax rate and the effective personal income tax rate.

- $\quad$ Reducing state control and influence over productive enterprises. We will exclude all companies in which the government has a minority share from all legal norms set for state-owned companies. The government's right in such companies will not extend beyond the rights of all other minority shareholders.

- We will also accelerate privatization of companies and banks, as envisaged in our plan adopted earlier in 2008. 


\section{Table 1. Belarus: Access and Phasing Under the Proposed Stand-By Arrangement}

\begin{tabular}{|c|c|c|c|}
\hline Date Available & $\begin{array}{l}\text { In millions } \\
\text { of SDRs }\end{array}$ & $\begin{array}{l}\text { In percent } \\
\text { of quota }\end{array}$ & Conditions \\
\hline January 12, 2009 & 517.798 & 134.01 & Board approval of Stand-by Arrangement \\
\hline May 15, 2009 & 275.080 & 71.19 & $\begin{array}{l}\text { Observance of end-March } 2009 \text { performance criteria and completion } \\
\text { of the first review }\end{array}$ \\
\hline August 15, 2009 & 275.080 & 71.19 & $\begin{array}{l}\text { Observance of end-June } 2009 \text { performance criteria and completion of } \\
\text { the second review }\end{array}$ \\
\hline November 15, 2009 & 275.080 & 71.19 & $\begin{array}{l}\text { Observance of end-September } 2009 \text { performance criteria and } \\
\text { completion of the third review }\end{array}$ \\
\hline February 15,2010 & 275.080 & 71.19 & $\begin{array}{l}\text { Observance of end-December } 2009 \text { performance criteria and } \\
\text { completion of the fourth review }\end{array}$ \\
\hline
\end{tabular}


Table 2. Quantitative and Continuous Performance Criteria 1/

(End-of-period; in billions of Belarusian rubels, unless otherwise indicated)

\begin{tabular}{lcccc} 
Stock & \multicolumn{4}{c}{2009} \\
2008 & \multicolumn{4}{c}{} \\
\cline { 2 - 4 } End- & Mar. & June & Sept & Dec \\
Nov. & Prog. & Prog. & Proj. & Proj. \\
\hline
\end{tabular}

\section{Performance criteria}

Cumulative flow from end-November 2008

Ceiling on the cash deficit of the republican government (- implies a surplus) 2/3/

$\begin{array}{ccccc}\ldots & -400 & -400 & -1100 & 0 \\ 2,541 & -510 & -486 & -647 & -647 \\ 2,112 & 74 & 780 & 1,566 & 1,709\end{array}$

Floor on net international reserves of the NBRB (in $\quad \begin{array}{lllll}2,541 & -510 & -486 & -647 & -647\end{array}$ millions of U.S. dollars) 4/

Ceiling on net domestic assets of the NBRB 5/

\section{rrears.}

Prohibition on the imposition or intensification of restrictions on the making of payments and transfers for current international transactions

Prohibition on the introduction or modification of multiple currency practices

Prohibition on the conclusion of bilateral payments agreements that are inconsistent with Article VIII

Prohibition on the imposition or intensification of import restrictions for balance of payments reasons

\section{Adjusters}

Republican government budget support and privatization proceeds (millions of US dollars)

Republican government project support

NBRB Balance of payments financing

$\begin{array}{cccc}1,625 & 21 & 21 & 21 \\ 70.5 & 70.5 & 70.5 & 70.4 \\ 0 & 0 & 0 & 0\end{array}$

Sources: Belarusian authorities; and Fund staff estimates and projections.

1/ Definitions are specified in the Technical Memorandum of Understanding (TMU). Targets for endSeptember and end-December 2009 will be set at the time of the first and second reviews respectively. $2 /$ The ceiling on the cash deficits of the republican government for end-September and end-December will be adjusted as described in paragraphs 32-34 of the TMU.

3/ Data are cumulative flows from end-December 2008.

4/ The floor on NIR of the NBRB will be adjusted as described in paragraph 25 of the TMU.

$5 /$ Calculated as base money less NIR. The ceiling on NDA will be adjusted using adjusted NIR figures. 


\section{Table 3: Prior Actions and Structural Benchmarks Under the Stand-By Arrangement}

Prior Actions

A1. Re-peg the exchange rate to a basket of currencies consisting of the U.S. dollar, the Russian ruble and the Euro, and apply a band of \pm 5 percent around the central parity. (MEFP 97)

A2. Eliminate additional deposit transfers from the central and local governments to commercial banks (MEFP $\$ 10)$

A3. Legal approval of a central government budget with a zero deficit by a Presidential decree. (MEFP q12)

A4. Limit the wage increase for budgetary workers in November 2008 to 5.3 percent (MEFP \13)

A5. Abolish the interest rate ceiling for rubel lending to the corporate sector by the President adopting an appropriate Resolution. (MEFP $\mid 8$ )

\section{Structural Benchmarks}

C1. Engage a qualified, experienced, and reputable consultant, on a competitive basis, to assist in preparing state-owned banks for partial or full privatization (MEFP $\$ 11$ )

$\mathrm{C} 2$. Eliminate the regulatory act imposing a general ceiling on monthly prices increases of $1 / 2$ percent (MEFP $\$ 17$ ).

C3. In line with FSAP recommendations, bring loan classification practices in line with best international practices (MEFP $q 9$ ).

C4. Refrain from approving any new directed lending programs financed with budget deposits (MEFP \10).
Status

Observed

Observed

\section{Date}

August 312009

March 312009

September 30, 2009

Continuous 


\section{BELARUS: TECHNICAL MEMORANDUM OF UNDERSTANDING (TMU)}

December 31, 2008

1. This memorandum sets out the understandings between Belarus's authorities and the IMF staff regarding the definitions of quantitative and structural performance criteria and indicative targets. These performance criteria and indicative targets are reported in Tables 2 and 3 of the Memorandum of Economic and Financial Policies (MEFP), attached to the Letter of Intent dated December 31, 2008.

2. Quantitative performance criteria are shown in Table 2. The definitions of these quantitative targets and the adjustment mechanisms are described in Section I below. Background on prior actions and structural benchmarks, where necessary, is given in Section I below. Reporting requirements are specified in Section II.

3. The exchange rates and the price of gold to be used for the purpose of monitoring the program are in Table 1 of this attachment, and projections for privatization proceeds and government foreign borrowing in Tables 2 and 3 .

\section{QUANTITATIVE TARGETS}

\section{A. Net International Reserves of the National Bank of the Republic of Belarus (NBRB)}

\section{Definition}

4. Net international reserves (NIR) of the NBRB are defined as the difference between usable gross international reserve assets and reserve liabilities, evaluated in U.S. dollars at the program exchange rates (see Table 1 below). Usable gross international reserves assets comprise all reserve assets of the NBRB denominated in foreign convertible currencies, to the extent that they are readily available for intervention in the foreign exchange market and held in first-rank international banks or as securities issued by G7 countries. Excluded from usable reserves, inter alia, are:

- any assets denominated in foreign currencies held at, or which are claims on, domestic institutions (i.e., institutions headquartered domestically, but located either domestically or abroad, or institutions headquartered abroad, but located domestically). Excluded are, inter alia, all foreign currency claims of the NBRB on domestic banks, and NBRB deposits held in domestic banks for trading purposes;

- $\quad$ any precious metals or metal deposits, other than monetary gold, held by the NBRB;

- $\quad$ any reserve assets that are: (i) encumbered; or (ii) pledged as collateral (in so far as not already included in foreign liabilities, or excluded from reserve assets); or (iii) frozen; 
- $\quad$ any reserve assets that are not readily available for intervention in the foreign exchange market, inter alia, because of lack of quality or lack of liquidity that limits marketability at the book price. 
5. For the purpose of this program, reserve liabilities comprise:

- all short-term liabilities of the NBRB vis-à-vis non-residents with an original maturity of one year or less;

- all foreign exchange liabilities to resident entities (e.g. claims in foreign exchange of domestic banks on the NBRB), excluding to the general government;

- $\quad$ the stock of IMF credit outstanding;

- the nominal value of all derivative positions ${ }^{11}$ of the NBRB and government, implying the sale of foreign currency or other reserve assets against domestic currency.

6. For program monitoring purposes, the stock of foreign assets and foreign liabilities of the NBRB shall be valued at program exchange rates, as described in paragraph 3 above. On this basis, and consistent with the definition above, the stock of NIR amounted to \$2,541 million on November 30, 2008.

\section{Adjustment mechanism}

7. The floor on the NIR of the NBRB is subject to an automatic adjuster, based on deviations of external balance of payments support (defined as disbursements from bilateral and multilateral creditors to the NBRB, or as Republican government ${ }^{12}$ budget support) from program projections (shown in Table 2 of the MEFP).

A. If the proceeds from external balance of payments support to the NBRB (in U.S. dollars evaluated at program exchange rates):

a) cumulatively exceeds program projections, the floor on the NIR of the NBRB will be adjusted upward by 100 percent of the excess in external balance of payments support;

b) in any quarter falls short of program projections, the floor on the NIR of the NBRB will be adjusted downward by 100 percent of the shortfall in that quarter, 50 percent of the shortfall in the previous quarter. Disbursements in excess of its programmed level in any quarter, will be fully applied to reduce the shortfall for the previous quarter in calculating the adjusted target.

B. If the proceeds from external Republican government budget support and external privatization proceeds (valued in U.S. dollars at program exchange rates):

\footnotetext{
${ }^{11}$ This refers to the notional value of the commitments, not the market value.

${ }^{12}$ As defined in paragraph 11 below.
} 
a) cumulatively exceed program projections, the floor on the NIR of the NBRB will be adjusted upwards by 50 percent of the excess in external balance of payments support.

b) in any quarter falls short of program projections, the floor on the NIR of the NBRB will be adjusted downward by 100 percent of the shortfall in that quarter, and 50 percent of the shortfall in the previous quarter. Disbursements in excess of its programmed level in any quarter, will be fully applied to reduce the shortfall for the previous quarter in calculating the adjusted target.

\section{B. Net Domestic Assets of the NBRB}

\section{Definition}

8. Net domestic assets (NDA) of the NBRB is defined as the difference between the NBRB's monetary base and its NIR.

- $\quad$ The NBRB's monetary base comprises notes and coins issued by the NBRB (excluding cash in vault in the NBRB), banks' balances held at the NBRB as required reserves, correspondent accounts and other deposits, and funds of customers at the NBRB, banks' investments in NBRB securities, and deposits of enterprises, organizations, and individuals at the NBRB in local and foreign currencies.

- $\quad$ The NIR of the NBRB is defined as in paragraph 4 above.

9. Performance against the NDA target will be measured at program exchange rates. On this basis, and consistent with the definition above, the NBRB's NDA amounted to BYR2,112 billion on November 30, 2008.

\section{Adjustment mechanism}

10. The ceiling on the NDA of the NBRB is subject to an automatic adjuster, based on deviations of external budget support (defined as disbursements from bilateral and multilateral creditors to the Republican government as budget support) and balance of payments support to the NBRB from program projections (shown in Table 2 of the MEFP). Specifically, for the purposes of adjusting the NDA target, the NIR of the NBRB, adjusted as in paragraph 7 above.

\section{Ceiling on the Cash Deficit of the Republican Government}

\section{Definitions}

11. The Republican government includes the central government ministries, and the funds included in the Republican budget, including the National Development Fund. In case the government establishes new extrabudgetary funds, they will be integrated into the Republican government.

12. The cash deficit of the Republican government will be measured from the financing side as the sum of (i) net domestic financing from banks and nonbanks, (ii) net external financing, and (iii) privatization receipts. 
(i) Net domestic financing consists of bank and nonbank financing to the Republican government and will be defined as follows:

i. The change in the claims on the Republican government of commercial banks minus the change in deposits held by the Republican government in commercial banks.

ii. The change in the claims on the Republican government of the NBRB minus the change in deposits of the Republican government held at the NBRB in Belarusian rubels and foreign currency.

iii. Net claims on the government of the commercial banks and the NBRB will be monitored based on the monetary survey prepared by the NBRB.

iv. Also included are any other liability instrument issued by the Republican government, for example, promissory notes, any other increase in liability of the Republican government to domestic nonbank institutions.

v. Net sales of Treasury bills, bonds, or other government securities to nonbank institutions and households (including nonresidents and nonresident financial institutions), plus any other increase in liability of the Republican government to domestic nonbank institutions.

(ii) Net external financing is defined as:

vi. Total of loans disbursed to the Republican government for general budget support and project financing (capital expenditure and net lending), the change in the stock of outstanding international bonds, net change in external arrears, change in the accounts of the Republican government abroad, minus amortization. Amortization includes all external debt-related payments of principal by the Republican government.

vii. Amortization to external creditors via third parties is accounted for at the time and in the amount of payment by the budget to the third party, rather than at the time of recognition of amortization by the external creditor.

(iii) Privatization receipts:

viii. The privatization receipts of the central government consist of all transfers of monies received by the Ministry of Finance in connection with the sale of Republican government assets, including privatization proceeds, which were transferred to the National Development Fund.

ix. This includes receipts from the sales of shares, the sale of assets and the sale of licenses with duration of 10 years and longer.

13. For the purposes of measuring the deficit of the Republican government, all flows to/from the budget in foreign currency will be converted into Belarusian rubels at the official exchange rate prevailing at close of business on the date of the transaction. On this basis, and consistent with the definition above, the cash deficit of the Republican government for the first nine months of 2008 amounted to BYR -3,336.3 billion.

\section{Adjustment mechanism}

14. The ceilings on the cash deficit of the Republican government for end-September and end-December are subject to automatic adjusters, based on deviations of external budget and 
project support and privatization receipts from program projections (shown in Table 2 of the MEFP). If the total proceeds from external budget and project support (excluding from international financial institutions) to the Republican government budget or privatization proceeds (in Belarusian rubels converted at the official exchange rate on the days of its receipt):

- $\quad$ cumulatively exceed program projections, the ceiling on the cash deficit of the Republican government will be adjusted upwards by 50 percent of the excess.

- $\quad$ cumulatively falls short of program projections, the ceiling on the cash deficit of the Republican budget will be adjusted downward by 50 percent of the shortfall in the previous quarter, if any. Disbursements in excess of its programmed level in any quarter, will be fully applied to reduce the shortfall, if any, for the previous quarter in calculating the adjusted target.

- $\quad$ For project support from international financial institutions, if disbursements in foreign currency exceed (fall short of) program projections, the ceiling on the cash deficit of the Republican government will be adjusted upwards (down) by 100 percent of the excess (shortfall) in project support.

15. The ceiling on the cash deficit of the Republican government is also subject to an automatic adjuster for recapitalization of banks. Specifically, the ceiling on the deficit will be adjusted upward for the amount of funds provided by the republican budget to banks to bring regulatory capital to minimum statutory levels.

16. The total adjustor annual for higher-than-programmed international financial assistance is capped at 1.8 percent of GDP.

\section{Continuous Performance Criteria on Non-accumulation of External Arrears}

17. During the period of arrangement, the Republican government and the NBRB will not accumulate any new external payments arrears on debt service obligations to official creditors. Official external payment arrears are defined as unpaid debt service by the Republican government and the NBRB beyond 30 days after the due date. The performance criterion on non-accumulation of external arrears is continuous.

\section{REPORTING REQUIREMENTS}

\section{A. National Bank of the Republic of Belarus}

18. The NBRB will provide to the IMF an aggregate balance sheet for the NBRB on the $1^{\text {st }}, 8^{\text {th }}, 15^{\text {th }}$, and $22^{\text {nd }}$ days of each month.

19. The NBRB will provide to the IMF on a weekly and monthly basis, no later than the 25 th of the following month, the full breakdown of NBRB accounts included in net international reserves (defined in paragraph 4), at both actual and program exchange rates. 
20. The NBRB will provide to the IMF on a weekly basis a data sheet on currency operations including Government foreign receipts and payments, breakdown of interbank market operations by currencies, explanations for main currency flows. The NBRB will also provide daily information on exchange market transactions, including exchange rates.

21. The NBRB will provide to the IMF, on a monthly basis, a projection for external payments falling due in the next twelve months.

22. The NBRB will provide to the IMF, on a quarterly basis, the stock of external debt for both public and private sector in the format of the IMF Debt Statistics Manual, Table 4.1 (http:/www.imf.org/external/pubs/ft/eds/eng/guide/index.htm). The public sector includes the Republican government; the private sector excludes banks and other non-banking financial institutions.

23. The NBRB will provide to the IMF on a monthly basis, no later than 25 days after the end of the month, financial soundness indicators for the banking sector in an agreed format, as well as the level of compliance of bank performance with the indicative parameters of banking sector development set by the Republic of Belarus monetary policy guidelines.

24. The NBRB will provide to the IMF consolidated bank balance sheet with loan classification (standard, watch, sub-standard, doubtful, loss) on a quarterly basis, no later than 30 days after the end of the quarter.

25. The NBRB will provide preliminary monthly balance of payments data in electronic format no later than forty-eight days after the end of the month.

26. The NBRB will inform IMF staff of any changes to reserve requirements for deposit money banks. The NBRB will communicate in writing to the IMF staff any changes in accounting conventions and valuation principles incorporated into the balance sheet data and will notify the staff before introducing any change to the Charts of Accounts of the NBRB and the Commercial Banks, as well as changes in the reporting forms.

\section{B. Ministry of Finance}

27. The Ministry of Finance will continue to provide to the IMF in electronic form monthly treasury reports, including revenue and expenditure figures of the consolidated Republican government budget and local budgets no later than 30 days after the end of the month. These reports will provide expenditure data by programs, and on standard functional and economic classifications. Data for local governments will be provided at similar frequency, but only on functional and economic classifications.

28. The Ministry of Finance will continue to report the final fiscal accounts at the end of each fiscal year, no later than March of the following year. These reports will provide 
expenditure data by programs, as well as based on standard functional and economic classifications.

29. The Ministry of Finance will report any revisions to monthly and annual fiscal reports of the Republican budget within a week after their approval.

30. The Ministry of Finance will continue to provide on its web site the weekly report on the primary treasury bill market, reports on each treasury bill auction, and provide to the IMF the monthly report on treasury bills.

31. The Ministry of Finance will inform IMF staff if the Treasury does not pay interest or principal on treasury bills due to the NBRB, deposit money banks, or non-bank entities and individuals. In such case, the Ministry of Finance will provide information on outstanding interest and principal payments.

32. The Ministry of Finance will provide available data on the stock of budgetary arrears on a monthly basis, no more than 30 days after the end of the month, including separate line items for wages, pensions and social benefits.

33. The Ministry of Finance will provide to the IMF in electronic format monthly information, no later than 30 days after the end of each month, on the amounts and terms of all external debt contracted or guaranteed by the general government.

34. The Ministry of Finance will provide to the IMF in electronic form on a monthly basis, no later than 30 days after the end of the month, (a) data on the outstanding stock of domestic and external debt of the Republican government, (b) the standard files on planned and actual external debt disbursement, amortization, and interest payments. The Ministry of Finance will also report the accumulation of any budgetary arrears on external and domestic debt service.

35. The Ministry of Finance and the NBRB will provide data on external and domestic credit to nongovernment units that is guaranteed by the Republican government or the NBRB on a monthly basis, no later than 30 days after the end of the month.

36. The Ministry of Finance will provide, no later than 30 days after the end of each quarter, quarterly data on the budgetary costs associated with the recapitalization of banks. This cost includes the upfront impact on the cash deficit of the Republican government of the recapitalization of banks as well as the costs associated with the payment of interests.

37. The Ministry of Finance will provide, no later than 30 days after the end of each quarter, quarterly data on the budgetary costs associated with sponsored loans under state programs, separately identifying the costs associated with subsidized loans extended below refinance rate, and the quarterly data on the amount of central and local government guarantees issued on bank loans. 
38. The Ministry of Economy will provide quarterly information on levels of communal service tariffs for population (heating, water supply, sewage, natural gas supply, maintenance, and rent for a family of three, living in a standard (total of 48 square meters apartment) and level of recovery of services' costs by population in accordance with existing methodology). 
Table 1. Program Exchange Rates, as of end-November, 2008

\begin{tabular}{l|lr} 
& Currency & $\begin{array}{c}\text { Currency per US dollar unless } \\
\text { indicated otherwise }\end{array}$ \\
\hline Gold 1/ & Gold & $\$ 814.5$ per troy ounce \\
SDR 2/ & Special Drawing Rights & 0.672057 \\
RBL 3/ & Belarusian rubel & 2,156 \\
RBR 4/ & Russian ruble & 27.4230 \\
EUR 5/ & Euro & 0.7746 \\
\hline
\end{tabular}

1/ Source: http://www.bankofengland.co.uk

2/ Rate as of November 28, 2008 (www.IMF.org).

3/ NBRB official rate as of November 30, 2008 disseminated on www.nbrb.by.

4/ CBR official rate as of November 29, 2008, disseminated on www.cbr.ru.

5/ Reference rate as of November 28, 2008, disseminated on www.ecb.int.

Table 2. Projected Foreign Borrowing of the Republican Government Related to Budget Support or Balance of Payments Financing

\begin{tabular}{l|cc}
\multicolumn{2}{c}{ (in millions of US\$) } \\
Date & Amount & Cumulative amount \\
\hline Quarter ending: & $1,000.0$ & $1,000.0$ \\
March 31, 2009 & 0 & $1,000.0$ \\
June 30, 2009 & 0 & $1,000.0$ \\
September 30, 2009 & 0 & $1,000.0$ \\
December 31, 2009 & & \\
\hline
\end{tabular}

Table 3. Projected Foreign Borrowing of the Republican Government Related to Project Financing (in millions of US\$)

\begin{tabular}{l|cccc} 
Date & Total amount & $\begin{array}{c}\text { Cumulative } \\
\text { Amount }\end{array}$ & $\begin{array}{c}\text { Amount } \\
\text { from IFIs }\end{array}$ & $\begin{array}{c}\text { Cumulative } \\
\text { amount from IFIs }\end{array}$ \\
\hline Quarter ending: & & & & \\
March 31, 2009 & 70.5 & 70.5 & 17.8 & 17.8 \\
June 30, 2009 & 70.5 & 141 & 17.8 & 36 \\
September 30, 2009 & 70.5 & 212 & 17.8 & 53 \\
December 31, 2009 & 70.4 & 282 & 17.7 & 71 \\
\hline
\end{tabular}

Table 4. Projected External Privatization Proceeds of the Republican Government Under the SBA1/ (in billions of BYR)

\begin{tabular}{l|cc} 
Date & Amount & Cumulative amount \\
\hline Quarter ending: & 1,656 & 1,656 \\
March 31, 2009 & 55 & 1,711 \\
June 30, 2009 & 55 & 1,766 \\
September 30, 2009 & 55 & 1,820 \\
December 31, 2009 & & \\
\hline
\end{tabular}




\section{INTERNATIONAL MONETARY FUND}

\section{REPUBLIC OF BELARUS}

\section{Request for Stand-By Arrangement Informational Annex}

\section{Prepared by the European Department \\ (In consultation with other departments and the World Bank)}

January 5, 2009

Contents

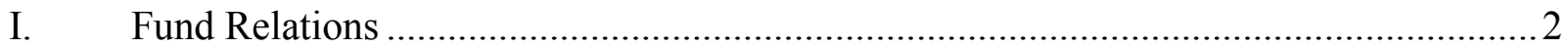

II. World Bank Relations .................................................................................. 7

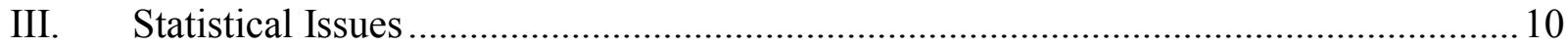


ANNEX I. BELARUS: Fund RELATIONS

As of November 30, 2008

I. Membership Status: Joined July 10, 1992; Article VIII

II. General Resources Account:

SDR million

Percent of Quota

Quota

386.40

100.00

Fund holdings of currency

386.40

100.00

Reserve position in Fund

0.02

0.01

III. SDR Department:

SDR million

Percent of Allocation

Holdings

0.62

N/A

IV. Outstanding Purchases and Loans: None

V. Financial Arrangements:

$\begin{array}{ccccc}\text { Type } & \begin{array}{c}\text { Approval } \\ \text { Date }\end{array} & \begin{array}{c}\text { Expiration } \\ \text { Date }\end{array} & \begin{array}{c}\text { Amount Approved } \\ \text { (SDR million) }\end{array} & \begin{array}{c}\text { Amount Drawn } \\ \text { (SDR million) }\end{array} \\ \text { Stand-by } & 09 / 12 / 1995 & 09 / 11 / 1996 & 196.28 & 50.00\end{array}$

VI. Projected Obligations to the Fund (SDR million; based on existing use of resources and present holdings of SDRs): None

\section{Safeguards Assessments:}

As there is no arrangement in place, under the Fund's safeguards assessments policy, the National Bank of the Republic of Belarus (NBRB) is not subject to a full safeguards assessment. However, as a potential borrower, the NBB requested a voluntary safeguards assessment, and an on-site assessment was conducted in December 2003. The assessment concluded that significant vulnerabilities existed in the safeguards framework, especially in the areas of the legal structure and independence, external and internal audit, and in financial reporting. The assessment made specific recommendations to correct the identified shortcomings. The authorities have begun to address some of these issues, and are considering appropriate measures to address the remaining concerns. 


\section{Exchange Arrangements:}

As of August 20,1994, the rubel $(\mathrm{Br})$ became the unit of account replacing the Belarusian ruble, which was formally recognized as the sole legal tender only on May 18, 1994. The conversion took place at the rate of 10 Belarusian rubles $=1$ rubel. The authorities decided to drop three zeroes from the rubel denomination as of January 1, 2000. The exchange rate for the U.S. dollar was BYR 2,200 on December 31, 2008.

In mid-September 2000, the official exchange rate was unified with the market-determined rate resulting from daily auctions at the Belarus Currency and Stock Exchange. Since then, the official rate on any day is equal to the closing rate of the previous trading day. On January 1, 2008 the exchange rate was set in the framework of horizontal corridor for the U.S. dollar around central parity. The earlier arrangement, introduced in 2006, entailed reference to two horizontal corridors around central parity for the Russian ruble ( \pm 4 percent) and U.S. dollar ( \pm 2.5 percent). On November 5, 2001, Belarus accepted the obligations of Article VIII, Sections 2, 3, and 4 of the IMF's Articles of Agreement. During the same month, the NBB suspended all ad hoc exemptions from the 30 percent surrender requirement. Based on currently available information, Belarus does not maintain exchange restrictions or multiple currency practices.

\section{UFR/Article IV Consultation:}

Belarus is on a 12-month consultation cycle. The $14^{\text {th }}$ Article IV consultation was concluded on June 4, 2007 Visits since have included:

Staff visit

February 19-26, 2008

\section{FSAP Participation, ROSCs, and OFC Assessments:}

The fiscal ROSC was published on http://www.imf.org/external/pubs/cat/longres.cfm?sk=17839.0 and the data ROSC on http://www.imf.org/external/pubs/cat/longres.cfm?sk=18013.0. Two FSAP missions took place in 2004 and an FSSA report was published on http://www.imf.org/external/pubs/cat/longres.cfm?sk=18367.0.

The detailed FSAPs were disseminated in May 2006 for the Basel Core Principles for Effective Banking Supervision on http://www.imf.org/external/pubs/cat/longres.cfm?sk=19246.0, for the Transparency of Monetary Policy and Banking Supervision on http://www.imf.org/external/pubs/cat/longres.cfm?sk=19248.0, and the Technical Note Deposit Insurance on http://www.imf.org/external/pubs/cat/longres.cfm?sk=19250.0. 


\begin{tabular}{|c|c|c|c|}
\hline XI. & Technical Assistance, & 0-08: & \\
\hline & $\begin{array}{l}\text { Department } \\
\text { Counterpart }\end{array}$ & Subject & Timing \\
\hline & MCM & $\begin{array}{l}\text { Exchange rate regime, foreign } \\
\text { exchange operations }\end{array}$ & December 8-15, 2008 \\
\hline & MCM & FSAP Update & September 2008 \\
\hline & $\mathrm{MCM}$ & $\begin{array}{l}\text { Financial stability and external debt } \\
\text { management }\end{array}$ & January 21-31, 2008 \\
\hline & $\mathrm{MCM}$ & $\begin{array}{l}\text { Banking supervision: financial } \\
\text { stability issues, stress-testing }\end{array}$ & July 23-27, 2007 \\
\hline & $\mathrm{MCM}$ & $\begin{array}{l}\text { Building a system for forecasting and } \\
\text { policy analysis }\end{array}$ & $\begin{array}{l}\text { June } 2-6,2008 \\
\text { October } 15-19,2007 \\
\text { July } 9-13,2007\end{array}$ \\
\hline & $\mathrm{MCM}$ & $\begin{array}{l}\text { Strengthening forecasting and policy } \\
\text { analysis }\end{array}$ & May $14-18,2007$ \\
\hline & $\mathrm{MCM}$ & $\begin{array}{l}\text { Banking supervision: on-site } \\
\text { inspection }\end{array}$ & April 23-May 8, 2007 \\
\hline & $\mathrm{MCM}$ & $\begin{array}{l}\text { Banking supervision: stress-testing, } \\
\text { financial stability }\end{array}$ & March 26-30, 2007 \\
\hline & $\mathrm{MCM}$ & Insurance supervision & March 12-21, 2007 \\
\hline & $\mathrm{MCM}$ & $\begin{array}{l}\text { Monetary policies analysis and } \\
\text { forecasting }\end{array}$ & February 5-9, 2007 \\
\hline & $\mathrm{MCM}$ & $\begin{array}{l}\text { Banking supervision: on-site } \\
\text { inspection }\end{array}$ & January $17-26,2007$ \\
\hline & $\mathrm{MCM}$ & Improving monetary policy & January $15-17,2007$ \\
\hline & $\mathrm{MCM}$ & $\begin{array}{l}\text { Monetary policies analysis and } \\
\text { forecasting }\end{array}$ & $\begin{array}{l}\text { October } 23-27,2006 \\
\text { October 9-13, } 2006\end{array}$ \\
\hline & $\mathrm{MCM}$ & $\begin{array}{l}\text { Banking supervision: on-site } \\
\text { inspection }\end{array}$ & October 18-25, 2006 \\
\hline & MFD & International accounting standards & August 28-September 1, 2006 \\
\hline & MFD & $\begin{array}{l}\text { Modeling capacity for supporting } \\
\text { monetary policy implementation }\end{array}$ & March 27-31, 2006 \\
\hline & MFD & Banking supervision & February $6-10,2006$ \\
\hline & MFD & $\begin{array}{l}\text { Monetary policy transmission } \\
\text { mechanism }\end{array}$ & December 12-16, 2005 \\
\hline & MFD & International accounting standards & October 24-28, 2005 \\
\hline & MFD & Improving monetary policy & June 20-July 10, 2005 \\
\hline
\end{tabular}




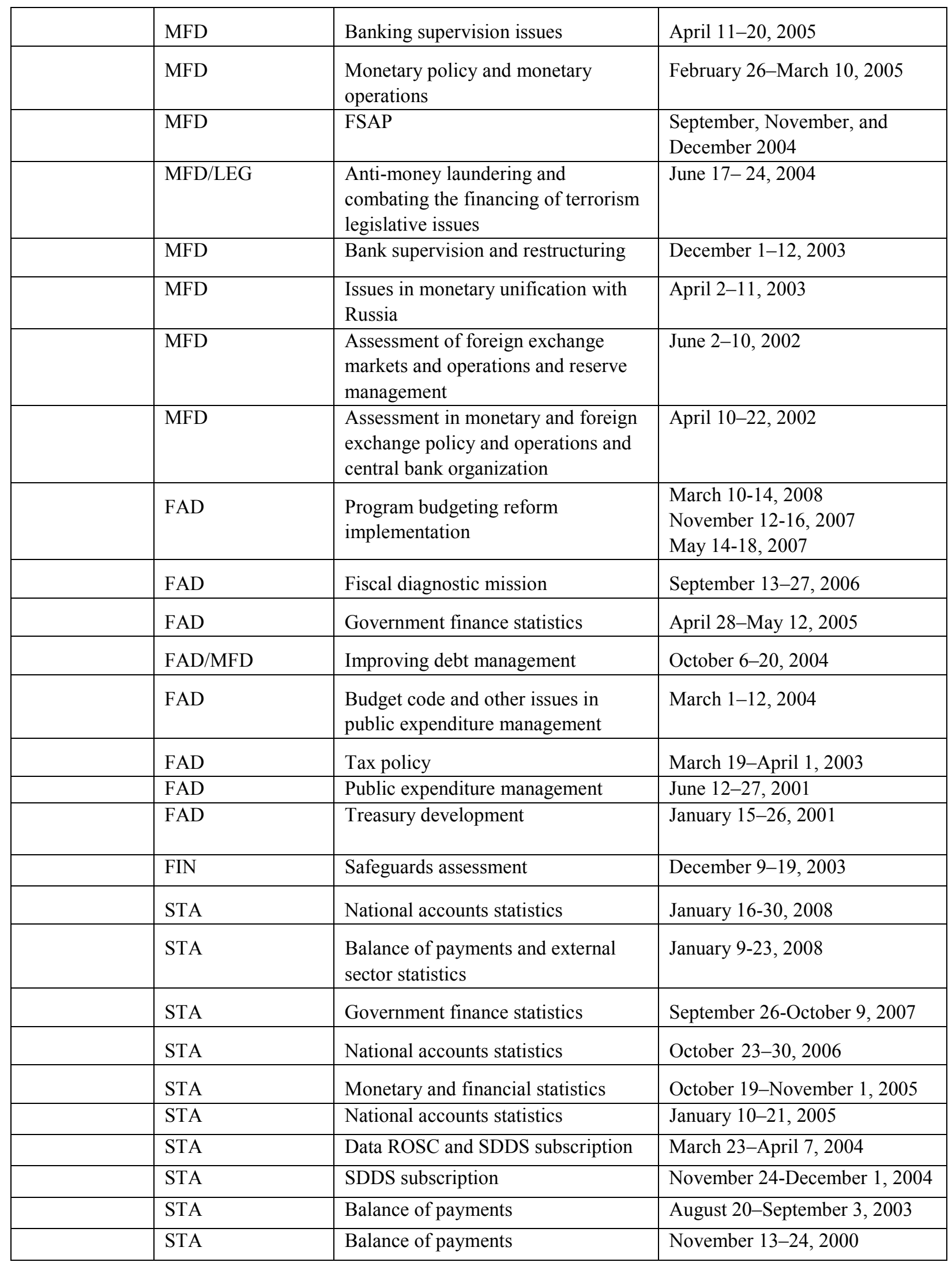




\begin{tabular}{|l|l|l|l|}
\hline & STA & Money and banking statistics & October 25-November 7, 2000 \\
\hline & STA & $\begin{array}{l}\text { Multisector statistics (report of the } \\
\text { resident advisor) }\end{array}$ & August 7, 1996-August 6, 2000 \\
\hline & STA & National accounts statistics & August 23-September 6, 2000 \\
\hline $\begin{array}{l}\text { Resident } \\
\text { Advisors }\end{array}$ & STA & $\begin{array}{l}\text { Mr. Umana } \\
\text { (General Statistics Advisor) }\end{array}$ & August 1996-August 2000 \\
\hline
\end{tabular}




\section{ANNEX II. BELARUS: RELATIONS WITH THE WORLD BANK GROUP}

\section{The World Bank Group Strategy}

1. A new WBG Country Assistance Strategy for Belarus for FY 2008-2011 was approved on December 4, 2007. The CAS program is aligned with selected government priorities consistent with the Bank's mandate. Under the new CAS, the Bank together with its development partners would continue to provide an analysis and advice, to advocate changes needed for sustainable development in Belarus, and to deliver limited financing interventions to advance issues of global interest, as well as to help vulnerable groups of the population. The World Bank plans to lend to Belarus US\$100 million a year in long-term loans to support the country in addressing global environment and energy challenges, enhancing the competitiveness of its economy to assure rising incomes, and protecting the welfare of the most vulnerable over the next four years. To date, the Bank's lending commitments in Belarus total US\$258 million, with US\$17.5 million provided as grants.

2. The IFC strategy would continue to foster private sector development through advisory services and investment operations. The IFC advisory services focus on reforms of business registration, permits, and the system of inspections, while retaining flexibility to respond to other government requests to improve the business environment. Outstanding IFC investments in Belarus total approximately US\$135 million; divided almost equally between financial markets and the real sector.

\section{IMF-World Bank Collaboration in Specific Areas}

3. The Bank and the Fund teams work closely in calibrating and delivering their assistance. The IMF plays a key role at the macro level, while the World Bank focuses on the structural agenda, energy efficiency, social and environmental issues. The Bank and the Fund teams carry out various joint activities. The joint work on the Public Expenditure Review (PER), Financial Sector Assessment Program (FSAP), and the Country Economic Memorandum (CEM) are examples of excellent cooperation between the two institutions.

\section{Areas in Which the World Bank Leads}

4. Structural and social issues, private business development. The Bank focuses its analytical work on structural reforms and on those issues that are most critical to reducing risks to the population posed by transition and external shocks. The new Country Economic Memorandum (under preparation) focuses on reforms needed to boost productivity, competitiveness, and export diversification. In FY08, the Bank will start to prepare the Social Sector Review in order to recommence the dialogue about reforming the pension system and strengthening the social safety net. The IFC delivers an active advisory program around challenges facing the private sector and international "best practices" for improving the business regulatory environment.

5. Energy sector. Currently, two energy efficiency projects are being implemented in Belarus with World Bank’s financial support: the Post Chernobyl Recovery Project (US\$50 million) and the Additional Financing for the Social Infrastructure Retrofitting Project (SIRP) (US\$15 million). The initial SIRP was supported by a World Bank loan of US\$22.6 
million and the associated PHRD grant for climate change. They were successfully completed in March 2008. Last FY the Bank started to prepare a new energy sector project.

6. Environment. The Bank supports Belarus' efforts in strengthening its environment institutions, addressing key public health challenges, and complying with its international commitments. Two TA projects are currently under implementation: (i) the IDF Grant for Enhancing Institutional and Legal Framework for Environmental Permitting in Belarus (US\$440,000); and (ii) the GEF Grant (US\$ 285,000) for preparation of the full-size Persistent Organic Pollutant (POPs) Stockpile Management and Technical/Institutional Capacity Upgrading Project. The Water Supply and Sanitation Project (US\$60 million) is expected to be approved during this FY and will finance investments in well field development and rehabilitation, water treatment, distribution network rehabilitation, and wastewater treatment.

\section{Areas of Shared Responsibility}

7. Macroeconomic development. The Bank's team cooperated closely with the IMF during preparation of the 2005 Country Economic Memorandum (CEM) and jointly prepared the chapter "Macroeconomic Policies and Risks". The two institutions will cooperate closely to prepare the macroeconomic chapter of the new CEM.

8. Public expenditure management. The IMF and the Bank provide continuous technical assistance to Belarus in public expenditure management. In 2007 the Bank prepared two policy notes in selected issues in public finance, which covered major issues in intergovernmental fiscal relations and capital budgeting. ${ }^{1}$ Belarus became a member of the Public Expenditure Management Peer Learning Program (PEMPAL) in 2006 and has benefited from participation in various events for practitioners in budget policy, treasury, and audit. IMF technical assistance missions support PFM improvement, ranging from treasury, budget classification, fiscal ROSC to program budgeting.

9. In FY 07 the Bank launched the Public Expenditure and Financial Accountability (PEFA) assessment for Belarus. The PEFA report will be the first comprehensive diagnosis of the overall PFM system in Belarus that could demonstrate strengths and weaknesses of the entire PFM system.

10. Debt management. A team of experts from the Banking and Debt Management Department (BDM) and the Capital Markets Development Department (CMD) of the World Bank Treasury will work in Belarus on September 9-19, 2008 to assess the needs of the Ministry of Finance in debt management and debt market development, to evaluate the current debt management strategy and practices, and to assist in designing a plan for their upgrading. The work will build on the findings of the IMF TA earlier missions in debt management and in access to capital markets.

11. Financial sector. The FSAP for Belarus (2004) focused on assessment of the banking system, including the deposit insurance, securities markets, the insurance industry, the payment system, and transparency in conducting monetary policy. Also, the 2004 FSAP reviewed regulations, oversight, and governance arrangements. Upon a GOB request, the

\footnotetext{
${ }^{1}$ Taking Stock of Intergovernmental Fiscal Relations: Issues, and Challenges; Selected Issues in Capital Expenditures--Improving the Quality of Public Capital Expenditures to Promote Growth, 2007, World Bank
} 
Bank and the IMF will undertake a FSAP Update in fall 2008. The Update will assess the systemic stability, the banking supervision, the access to financial services, securities market development and the insurance regulatory regime.

\section{Areas in Which the IMF Leads}

12. The IMF is actively engaged with the authorities in discussing the macroeconomic program, providing technical assistance and related support, including support on economic and financial statistics, tax policy, monetary operations, and fiscal transparency. The IMF is leading the dialogue on setting the objectives for monetary and exchange rate policies, public debt management, overall budget envelope, and tax policy.

13. The IMF analysis in these areas serves as an input to the Bank policy advice. The Bank and the IMF teams have regular consultations, and the Bank staff takes part in the IMF Article IV Consultations. This helps to ensure consistency of policy recommendations by the two institutions.

14. Questions may be referred to Sergiy Kulyk, Country Program Coordinator, ECA Region, World Bank (202) 458-4068 


\section{ANNEX III. BELARUS: STATISTICAL ISSUES}

1. The quality and timeliness of statistical data are broadly adequate for surveillance, although macroeconomic analysis is encumbered in some areas. The authorities have made significant efforts and improvements over the past years in a number of key areas, with the support of technical assistance from the Fund. As a subscriber to the SDDS since December 2004, Belarus disseminates regularly prescribed series, an advance release calendar and maintains a National Statistics Data Page (http://www.belstat.gov.by/homep/en/specst/np.htm). The provision of data over 2007 through mid-2008 has generally been adequate for the analysis of economic developments on a regular basis.

2. The data ROSC mission that visited Minsk in early 2004 found that all statistical agencies face the challenge of increasing users' confidence in the accuracy and reliability of official statistics.

\section{National Accounts}

3. National accounts are compiled in accordance with the System of National Accounts of 1993 (SNA 1993). GDP is compiled by the production, the expenditure and the income approaches, and covers the entire economic territory of the Republic of Belarus. Data on GDP are disseminated on a quarterly basis (in national currency) in current and constant market prices $(2000=100)$ expressed as absolute values.

4. In early 2006, the Ministry of Statistics and Analysis (MinStat) introduced a new methodology early 2006 for measuring industrial production in constant prices (on the basis of prices of the previous year). In October 2006, a national account mission reviewed the methodology. It found that it is remains essentially based on quantity measures and noted the limitations of such measures for dealing with issues such as the introduction of new products and improvements in quality. Besides, the methodology relies on a limited number of deflators to derive intermediate consumption in constant prices, that hamper a proper capture of volume and price breakdown and may introduce a systematic bias in measuring industrial output.

5. In addition, GDP figures are likely to be distorted by the underreporting of newly emerging sectors - in particular services - and an active informal sector. In addition, problems remain in calculating holding gains from inventories, and in measuring the capital stock and consumption of fixed capital. Estimates of GDP by expenditure categories are still uncertain as the statistical discrepancy has been soaring.

\section{Prices}

6. Data on Consumer Price Index (CPI) and the Producer Price Index (PPI) are being reported to the Fund monthly on a timely basis. Both indices were developed with substantial technical assistance from the Fund. As regards the PPI, in January 1995 a Lapsers formula recommended by the Fund was adopted. Other recommendations, such as inclusion of exports, adequate specification of items, and better selection of representative products and prices, have either been adopted or are in the process of being adopted. Since January 
2001, the PPI has been compiled using the 1999 weights; and beginning with 2003 data, with 2001production weights.

\section{Government Finance Statistics}

7. Since the 2004 data ROSC mission, the MOF has made progress in different areas of collection, compilation, and dissemination of fiscal data. The authorities have extended the coverage of the general government (republican and local government) operations by including data for innovation funds, included the Social Protection Fund's operations in the consolidated budget, increased the number of officials involved in the GFS compilation work, established a close coordination with the National Bank of the Republic of Belarus(NBRB) for the reconciliation of fiscal and monetary datasets, and increased provision of detailed budgetary metadata and methodological descriptions on the MOF's website. In addition to these improvements, the MOF has prepared new budgetary classifications codes for revenue, expenditure, and financing data that will align them to the GFSM 2001 analytical framework.

8. At the end of April 2005, a GFS technical assistance (TA) mission visited Minsk. This mission found that the existing fiscal, accounting, and statistical systems have a sound basis for migrating to the GSFM 2001. Nonetheless, several areas were identified that will need further work before satisfactory implementation of the GFSM 2001. In order to provide assistance in this area, the GFS TA mission collaborated with the authorities on the preparation of a migration plan for a gradual implementation of this analytical framework.

9. The authorities have reported GFS for 2003 and 2004 under the GFSM 2001 analytical framework for publication in the GFS Yearbook and started disseminating, through the Move's website, fiscal data according to the IMF's Special Data Dissemination Standard.

\section{Monetary Statistics}

10. The balance sheet of the NBRB and the monetary survey are usually provided with a lag of no more than two weeks; the bank monthly balance sheet is available on or about the fifth of the month following the reference period, while monetary data for publication in IFS are reported with a lag of about four weeks.

11. Interest rate data on bank deposits and credits, as well as data on NBRB credit auctions and the placement of NBRB and government securities, are provided with a one month lag. Exchange rate data are readily available on the NBRB's web site, and periodically reported to the Fund in electronic file.

12. Following STA technical assistance mission in October 2005, the NBRB compiles monetary statistics according to the methodology of the Monetary and Financial Statistics Manual. The NBRB reports monetary data to STA using the Standardized Report Forms (SRFs) framework. Monetary and financial data for Belarus in the SRF framework are available from December 2001 and have been published in the December 2006 issue of the IFS Supplement. 


\section{Balance of Payments Statistics}

13. The overall quality and timeliness of external sector data is satisfactory. The International Transactions Reporting System employed by the NBRB has been broadened to permit a more accurate classification of external transactions, while coverage and reporting forms for enterprise surveys were also improved. The NBRB publishes quarterly balance of payments and international investment position statements in the BPM5 format on a timely basis. Scheduled interest and amortization payments on public sector debt are tracked by the MoF and reported to the Fund, and timely information is available on arrears on government and government-guaranteed debt.

14. Belarus has started to disseminate historical data on the reserves template on the IMF's website: http://www.imf.org/external/np/sta/ir/colist.htm Monthly time series start with November 2004 data. 
Belarus: TABLE OF COMMON INDICATORS REQUIRED FOR SURVEILLANCE

(As of August 22, 2008)

\begin{tabular}{|c|c|c|c|c|c|c|c|}
\hline & \multirow{2}{*}{$\begin{array}{l}\text { Date of latest } \\
\text { observation }\end{array}$} & \multirow{2}{*}{$\begin{array}{l}\text { Date } \\
\text { received }\end{array}$} & \multirow{2}{*}{$\begin{array}{c}\text { Frequenc } \\
\text { y of } \\
\text { data }^{6}\end{array}$} & \multirow{2}{*}{$\begin{array}{l}\text { Frequenc } \\
\text { y of } \\
\text { reporting } \\
6\end{array}$} & \multirow{2}{*}{$\begin{array}{l}\text { Frequency } \\
\text { of } \\
\text { publication }^{6}\end{array}$} & \multicolumn{2}{|c|}{ Memo Items: } \\
\hline & & & & & & $\begin{array}{c}\text { Data Quality } \\
- \\
\text { Methodologi } \\
\text { cal } \\
\text { soundness }^{7}\end{array}$ & $\begin{array}{l}\text { Data Quality } \\
\text { Accuracy } \\
\text { and reliability }\end{array}$ \\
\hline Exchange Rates & $8 / 22 / 08$ & $8 / 22 / 08$ & $\mathrm{D}$ & $\mathrm{D}$ & $\mathrm{D}$ & & \\
\hline $\begin{array}{l}\text { International Reserve Assets and Reserve } \\
\text { Liabilities of the Monetary Authorities } 1\end{array}$ & 7/31/08 & $8 / 15 / 08$ & M & M & M & & \\
\hline Reserve/Base Money & $7 / 31 / 08$ & $8 / 15 / 08$ & M & M & M & O, O, LO, LO & $\mathrm{O}, \mathrm{O}, \mathrm{O}, \mathrm{O}, \mathrm{O}$ \\
\hline Broad Money & $7 / 31 / 08$ & $8 / 14 / 08$ & M & M & M & & \\
\hline Central Bank Balance Sheet & $7 / 31 / 08$ & $8 / 14 / 08$ & M & M & M & & \\
\hline $\begin{array}{l}\text { Consolidated Balance Sheet of the Banking } \\
\text { System }\end{array}$ & $7 / 31 / 08$ & $8 / 14 / 08$ & M & M & M & & \\
\hline Interest Rates ${ }^{2}$ & $8 / 22 / 08$ & $8 / 22 / 08$ & $\mathrm{D} / \mathrm{W} / \mathrm{M}$ & $\mathrm{D} / \mathrm{W} / \mathrm{M}$ & $\mathrm{D} / \mathrm{W} / \mathrm{M}$ & & \\
\hline Consumer Price Index & June. 2008 & $8 / 13 / 08$ & M & M & M & O, LO, O, LO & $\mathrm{O}, \mathrm{O}, \mathrm{LO}, \mathrm{LO}, \mathrm{O}$ \\
\hline $\begin{array}{l}\text { Revenue, Expenditure, Balance and } \\
\text { Composition of Financing }{ }^{3}-\text { General } \\
\text { Government }^{4}\end{array}$ & 2008Q2 & $\begin{array}{l}8 / 25 / 200 \\
8\end{array}$ & Q & Q & Q & LO, LNO, O, O & $\mathrm{O}, \mathrm{O}, \mathrm{O}, \mathrm{O}, \mathrm{NO}$ \\
\hline $\begin{array}{l}\text { Revenue, Expenditure, Balance and } \\
\text { Composition of Financing }{ }^{3}-\text { Central } \\
\text { Government }\end{array}$ & July 2008 & $\begin{array}{l}\text { August } \\
25,2008\end{array}$ & M & M & Q & & \\
\hline $\begin{array}{l}\text { Stocks of Central Government and Central } \\
\text { Government-Guaranteed Debt }{ }^{5}\end{array}$ & July 2008 & $\begin{array}{l}\text { August } \\
25,2008\end{array}$ & M & M & Q & & \\
\hline External Current Account Balance & Q1 2008 & $6 / 13 / 08$ & Q & Q & Q & O, O, LO, LO & LO, O, O, O, O \\
\hline Exports and Imports of Goods and Services & Q1 2008 & $6 / 13 / 08$ & Q & Q & Q & & \\
\hline GDP/GNP & Q1 2008 & $6 / 30 / 08$ & Q & Q & Q & $\mathrm{O}, \mathrm{O}, \mathrm{LO}, \mathrm{O}$ & $\begin{array}{l}\text { LO, LNO, LO, O, } \\
\text { LO }\end{array}$ \\
\hline Gross External Debt & Q1 2008 & $6 / 13 / 08$ & Q & Q & NA & & \\
\hline International Investment Position & Q1 2008 & $6 / 13 / 08$ & $A$ & A & A & & \\
\hline
\end{tabular}

${ }^{1}$ Includes reserve assets pledged or otherwise encumbered as well as net derivative positions.

${ }^{2}$ Both market-based and officially-determined, including discount rates, money market rates, rates on treasury bills, notes and bonds.

${ }^{3}$ Foreign, domestic bank, and domestic nonbank financing.

${ }^{4}$ The general government consists of the central government (budgetary funds, extra budgetary funds, and social security funds) and state and local governments.

${ }^{5}$ Including currency and maturity composition.

${ }^{6}$ Daily (D); Weekly (W); Monthly (M); Quarterly (Q); Annually (A); Irregular (I); Not Available (NA).

${ }^{7}$ Reflects the assessment provided in the data ROSC published on May 2004 and based on the findings of the mission that took place during October 8-23, 2003 for the dataset corresponding to the variable in each row. The assessment indicates whether international standards concerning (respectively) concepts and definitions, scope, classification/sectorization, and basis for recording are fully observed (O), largely observed (LO), largely not observed (LNO), or not observed (NO).

${ }^{8}$ Same as footnote 7, except referring to international standards concerning (respectively) source data, statistical techniques, assessment and validation of source data, assessment and valid. 


\section{INTERNATIONAL MONETARY FUND}

\section{Republic of Belarus-Assessment of the Risks to the Fund and the Fund's Liquidity Position}

Prepared by the Finance and Strategy, Policy, and Review Departments

In consultation with other Departments

Approved by Andrew Tweedie and Athanasios Arvanitis

January 8, 2009

1. This note assesses the risks to the Fund arising from the proposed Stand-By Arrangement (SBA) for Belarus and its effects on the Fund's liquidity, in accordance with the policy on exceptional access. The authorities are requesting a 15-month SBA with access of SDR 1.618 billion (418.8 percent of quota). The arrangement would be frontloaded with a first purchase in an amount equivalent to SDR 517.8 million (134 percent of quota) upon approval. Three quarterly purchases each providing access in an amount equivalent to SDR 275.1 million (71.2 percent of quota) in 2009 and a final purchase in an amount equivalent to SDR 275.1 million (71.2 percent of quota) in February 2010 would be envisaged under the arrangement (Table 1).

Table 1. Belarus: Proposed SBA-Access and Phasing

\begin{tabular}{llrrr}
\hline \multirow{2}{*}{ Availability } & Date 1/ & \multicolumn{3}{c}{ Purchases } \\
\cline { 3 - 5 } 2009 & January (approval) & 517.8 & 134.0 & Percent of quota \\
\cline { 3 - 5 } & May & 275.1 & 71.2 & 134.0 \\
& August & 275.1 & 71.2 & 205.2 \\
& November & 275.1 & 71.2 & 276.4 \\
& February & 275.1 & 71.2 & 347.6 \\
& & & & 418.8 \\
& Total & $1,618.1$ & 418.8 & 418.8 \\
\hline
\end{tabular}

Source: Finance Department.

1/ Starting from May 2009, purchases will depend on the completion of a review. 


\section{BACKGROUND}

2. Belarus has received financial assistance from the Fund under two arrangements since becoming a member in July 1992 (Table 2). Belarus made all of the purchases under an arrangement under the systemic transformational facility (STF) approved in 1993 in an amount equivalent to SDR 140.2 million. A Stand-By arrangement was approved in September 1995 in an amount equivalent to SDR 196.3 million, of which only an amount equivalent to SDR 50 million was purchased. Belarus performed poorly under the program; several policy commitments were not implemented and external assistance from several sources was curtailed. Belarus has no credit outstanding with the Fund, and has repurchased Fund resources in a timely fashion (Figure 1).

Table 2. Belarus: IMF Financial Arrangements, Purchases and Repurchases under the GRA, 1993-2015 1/ (In millions of SDRs)

\begin{tabular}{|c|c|c|c|c|c|c|c|c|c|c|}
\hline Year & $\begin{array}{l}\text { Type of } \\
\text { Facility }\end{array}$ & & $\begin{array}{c}\text { Date of } \\
\text { Arrangement }\end{array}$ & $\begin{array}{c}\text { Date of } \\
\text { Expiration or } \\
\text { Cancellation }\end{array}$ & $\begin{array}{l}\text { Amount } \\
\text { Approved }\end{array}$ & $\begin{array}{l}\text { Amount } \\
\text { Drawn }\end{array}$ & Purchases & & Repurchases 2/ & Fund Exposure 2/ 3/ \\
\hline 1993 & STF & $4 /$ & 02-Aug-1993 & & 140.2 & 140.2 & 70.1 & & -- & 70.1 \\
\hline 1994 & & & & & & & - & & -- & 70.1 \\
\hline 1995 & SBA/STF & & 12-Sep-1995 & 11-Sep-1996 & 196.3 & 50.0 & 120.1 & $5 /$ & -- & 190.2 \\
\hline 1996 & & & & & & & -- & & -- & 190.2 \\
\hline 1997 & & & & & & & -- & & -- & 190.2 \\
\hline 1998 & & & & & & & -- & & 17.9 & 172.3 \\
\hline 1999 & & & & & & & -- & & 42.5 & 129.7 \\
\hline 2000 & & & & & & & -- & & 42.1 & 87.6 \\
\hline 2001 & & & & & & & -- & & 23.4 & 64.3 \\
\hline 2002 & & & & & & & -- & & 23.4 & 40.9 \\
\hline 2003 & & & & & & & -- & & 23.4 & 17.5 \\
\hline 2004 & & & & & & & -- & & 11.7 & 5.8 \\
\hline 2005 & & & & & & & -- & & 5.8 & 0.0 \\
\hline 2006 & & & & & & & -- & & -- & 0.0 \\
\hline 2007 & & & & & & & -- & & -- & 0.0 \\
\hline 2008 & & & & & & & -- & & -- & 0.0 \\
\hline 2009 & $S B A$ & & 05-Jan-2009 & 05-Apr-2010 & $1,618.1$ & & $1,343.1$ & & 0.0 & $1,343.1$ \\
\hline 2010 & & & & & & & 275.1 & & 0.0 & $1,618.3$ \\
\hline 2011 & & & & & & & 0.0 & & 0.0 & $1,618.3$ \\
\hline 2012 & & & & & & & 0.0 & & 297.3 & $1,320.9$ \\
\hline 2013 & & & & & & & 0.0 & & 774.7 & 546.2 \\
\hline 2014 & & & & & & & 0.0 & & 511.8 & 34.4 \\
\hline 2015 & & & & & & & 0.0 & & 34.4 & 0.0 \\
\hline
\end{tabular}

Source: Finance Department.

1/ Figures under the proposed program in italics.

2/ Following obligations schedule on the proposed arrangement.

$3 /$ As of end-December, unless otherwise indicated.

4/ The IMF established the Systemic Transformation Facility (STF) as a temporary financing window to provide assistance to member countries facing balance of payments difficulties arising from severe disruptions on their traditional trade and payments arrangements owing to a shift from reliance on trading at non market prices to a multilateral market-based system. The STF was created in April 1993 and allowed to lapse in April 1995.

5 / Includes a second drawing under the 1993 STF of SDR 70.1 million. 
Figure 1. Belarus: IMF Credit Outstanding, 1984-2008

(In millions of SDRs)

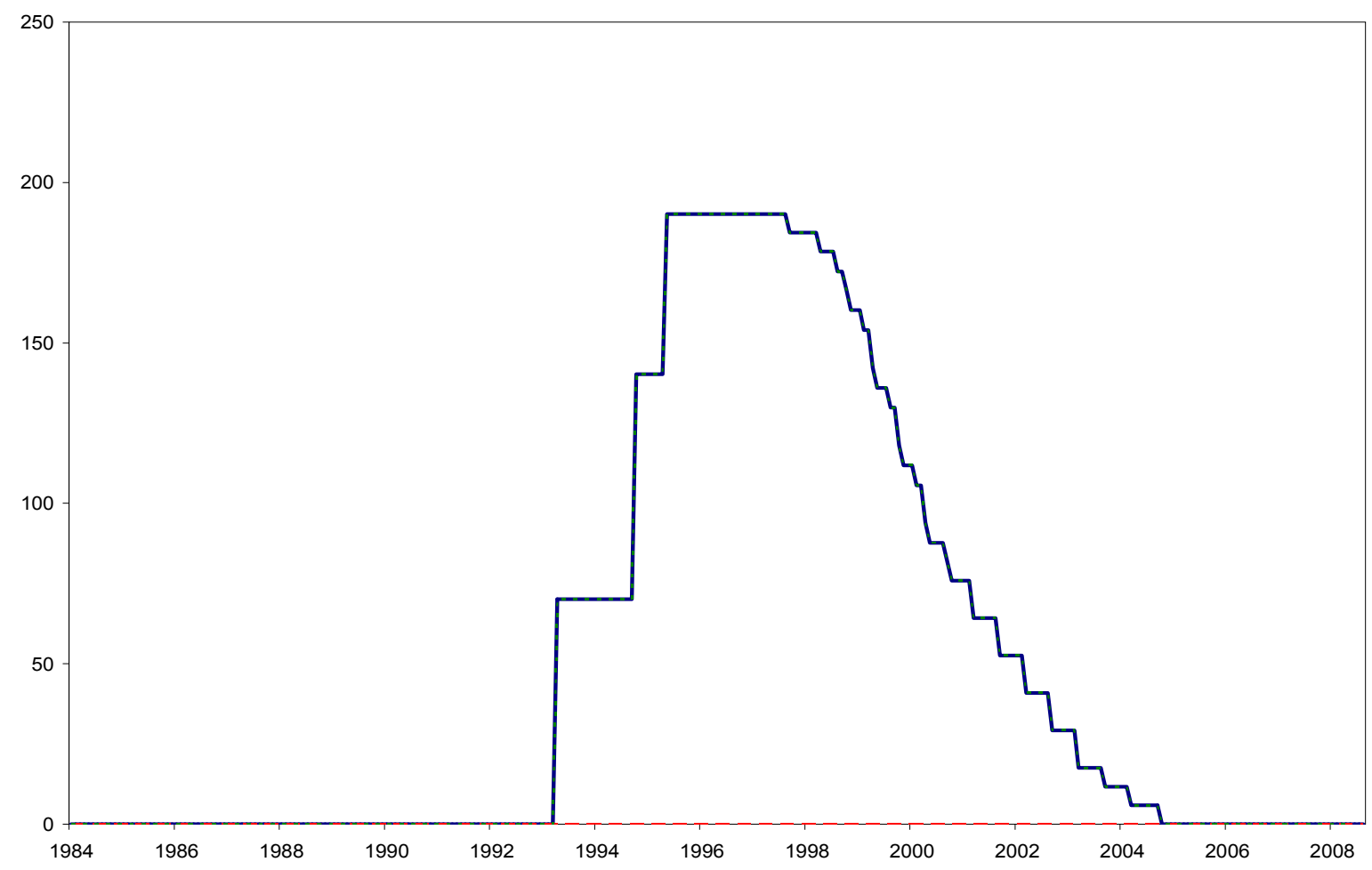

3. Belarus' total external debt is low, although it has increased in recent years (Tables 3). At end-2008, Belarus' public external debt was estimated at 5.9 percent of GDP, while total external debt, including debt of state enterprises, was estimated at 25.3 percent of GDP. As such, Belarus' external and external public debt ratios were below the corresponding ratios in the four previous exceptional access cases from 2003-05 and all six exceptional access cases approved since September 2008 (Table 4). ${ }^{1}$

\section{The NeW Stand-By ARRAngement-Risks ANd IMPACT ON FUnd's FinAnCES}

\section{A. Risks to the Fund}

\section{Access under the proposed arrangement would far exceed that in previous} arrangements for Belarus, and would exceed both the annual and cumulative limits. If all purchases are made as scheduled, Belarus' outstanding use of Fund resources would rise to over 130 percent of quota with the first drawing. Access would reach 418.8 percent of

\footnotetext{
${ }^{1}$ The previous exceptional access cases used as comparators in this paper are four of the five arrangements approved since the exceptional access procedures were put in place (Argentina, Brazil, Turkey, and Uruguay), while the recent cases are those approved in 2008. The 2008 extended arrangement for Liberia also involved exceptional access. However, this arrangement was different from other exceptional access cases since, in this case, exceptional access was granted in the context of Liberia's clearance of arrears to the Fund.
} 
Table 3. Belarus: External Debt, 2005-2008 1/

\begin{tabular}{|c|c|c|c|c|c|}
\hline & & 2005 & 2006 & 2007 & 2008 \\
\hline & & \multicolumn{4}{|c|}{ (In millions of U.S. dollars) } \\
\hline Total External Debt & & 5,130 & 6,847 & 12,548 & 15,101 \\
\hline \multirow[t]{8}{*}{ of which: } & Public 2/ & 785 & 839 & 2,933 & 3,532 \\
\hline & Multilateral & 82 & 65 & 51 & 50 \\
\hline & IMF & - & - & - & - \\
\hline & World Bank & 59 & 49 & 41 & 41 \\
\hline & Other Multilateral & 23 & 15 & 10 & 9 \\
\hline & Bilateral and Other & 702 & 773 & 2,286 & 3,184 \\
\hline & Private (mostly state-owned enterprises) & 4,345 & 6,009 & 9,615 & 11,569 \\
\hline & & \multicolumn{4}{|c|}{ (In percent of GDP) } \\
\hline \multirow{8}{*}{$\begin{array}{l}\text { Total External Debt } \\
\text { of which: }\end{array}$} & & 17.0 & 18.5 & 28.0 & 25.3 \\
\hline & Public 2/ & 2.6 & 2.3 & 6.6 & 5.9 \\
\hline & Multilateral & 0.3 & 0.2 & 0.1 & 0.1 \\
\hline & IMF & - & - & - & - \\
\hline & World Bank & 0.2 & 0.1 & 0.1 & 0.1 \\
\hline & Other Multilateral & 0.1 & 0.0 & 0.0 & 0.0 \\
\hline & Bilateral and Other & 2.3 & 2.1 & 5.1 & 5.3 \\
\hline & Private (mostly state-owned enterprises) & 14.4 & 16.3 & 21.5 & 19.4 \\
\hline
\end{tabular}

Sources: Belarus authorities and IMF staff estimates.

1/ Figures for 2008 include staff projections.

2/ Gross consolidated debt of the public sector (general government, central bank, and guarantees extended to non-financial public enterprises).

Table 4. Debt Ratios in Recent Exceptional Access Cases 1/ (In percent of GDP)

\begin{tabular}{|c|c|c|c|}
\hline & Total External Debt & Public External Debt & Debt to IMF \\
\hline \multicolumn{4}{|c|}{ A. Earlier arrangements, 2003-05: } \\
\hline Argentina (2003) & 129.0 & 82.5 & 12.2 \\
\hline Brazil (2003) & 38.6 & 21.5 & 5.1 \\
\hline Turkey (2005) & 35.0 & 17.8 & 3.0 \\
\hline Uruguay (2005) & 82.0 & 60.8 & 13.8 \\
\hline \multicolumn{4}{|c|}{ B. Newly approved arrangements (2008): } \\
\hline Georgia 2/ & 34.6 & 21.0 & 2.8 \\
\hline Hungary $3 /$ & 106.4 & 37.6 & 4.2 \\
\hline Ukraine $3 /$ & 54.3 & 10.4 & 2.5 \\
\hline Iceland 4/ & 165.0 & 99.9 & 5.1 \\
\hline Pakistan 6/ & 31.4 & 29.5 & 3.5 \\
\hline Latvia $7 /$ & 129.2 & 10.2 & 2.8 \\
\hline Belarus (2009) 8/ & 25.3 & 5.9 & 1.3 \\
\hline
\end{tabular}

Sources: Board documents and IMF staff estimates.

1/ Ratios for the year indicated in parenthesis. Year in parenthesis corresponds to the year of approval of the last IMF arrangement with each country.

2/ End-2008 projection, including PRGF resources.

3/ End-2008 projection.

4/ End-2008 projection

5/ End-2008 projection. Estimate excludes US\$84.8 billion (505 percent of GDP) of banks' external debt. 6/ End-2008 projection.

7/ End-2008 projection, assuming first purchase under proposed arrangement.

8/ Ratios for total external debt and public external debt are end-2008 estimates. The Debt to IMF ratio is calculated as the first purchase under the proposed arrangement divided by the 2008 GDP (both in U.S. dollars). 
quota in February 2010 - well above Belarus' historic peak exposure - and remain at this level through March 2012. ${ }^{2}$ In terms of quota, this peak exposure would be smaller than that in previous and recent exceptional access cases, except for Georgia (Figure 2).

\section{Under the proposed SBA, Belarus' total outstanding use of Fund resources will} be 1.3 percent of GDP following the first purchase, and 3.9 percent of GDP after the final disbursement (Tables 5 and 6). Belarus' outstanding use of Fund resources in terms of GDP would be lower than the ratios for most of the recent exceptional access cases. Taking into account the first purchase under the arrangement, Belarus would become the Fund's seventh largest user of Fund resources, after Latvia and before Liberia.

Table 5. Fund GRA Exposure

\begin{tabular}{|c|c|c|c|c|c|}
\hline & \multirow[b]{3}{*}{ SDR Millions } & \multicolumn{4}{|c|}{ In Percent of } \\
\hline & & \multirow[b]{2}{*}{ Quota } & \multirow[b]{2}{*}{ GDP 3/ } & \multicolumn{2}{|c|}{ Total GRA Credit } \\
\hline & & & & $\begin{array}{c}\text { As of end- } \\
\text { December, } 2008\end{array}$ & $\begin{array}{c}\text { After approval of } \\
\text { proposed } \\
\text { arrangement 4/ }\end{array}$ \\
\hline \multicolumn{6}{|c|}{ Top five borrowers as of end-December, 2008 1/ } \\
\hline Turkey & $5,534.4$ & 464.6 & 1.1 & 31.6 & 30.7 \\
\hline Hungary & $4,215.0$ & 405.9 & 4.1 & 24.1 & 23.4 \\
\hline Ukraine & $3,057.3$ & 222.8 & 2.5 & 17.4 & 16.9 \\
\hline Pakistan & $2,072.1$ & 200.5 & 2.1 & 11.8 & 11.5 \\
\hline Iceland & 560.0 & 476.2 & 4.7 & 3.2 & 3.1 \\
\hline Belarus 2/ & 517.8 & 134.0 & 1.3 & 3.0 & 2.9 \\
\hline
\end{tabular}

Sources: Finance Department and IMF staff estimates.

1/ Fund credit outstanding as of end-December, 2008.

2/ Fund credit outstanding after the first purchases of the proposed SBA.

3/ Staff projections to end-2008.

4/ Numerator is Fund credit outstanding as of end-December 2008. Denominator is the sum of total Fund GRA credit outstanding as of endDecember 2008 and the first purchase of the proposed arrangement.

\footnotetext{
${ }^{2}$ Debt service to the Fund is calculated on an obligations basis. Under the obligations schedule, the first repurchase is scheduled to take place in April 2012, 31/4 years after the first purchase under the arrangement. Under the policy on time-based repurchase expectations, there is an expectation that repurchases of holdings resulting from the purchases in the credit tranches and the EFF, including under exceptional access will adhere to the expectations schedule, and an extension from the expectations to the obligations schedule would require a decision by the Executive Board.
} 


\section{Figure 2. Fund Credit Outstanding in the GRA Around Peak Borrowing 1/ (In percent of quota)}

A. Previous Exceptional Access Cases

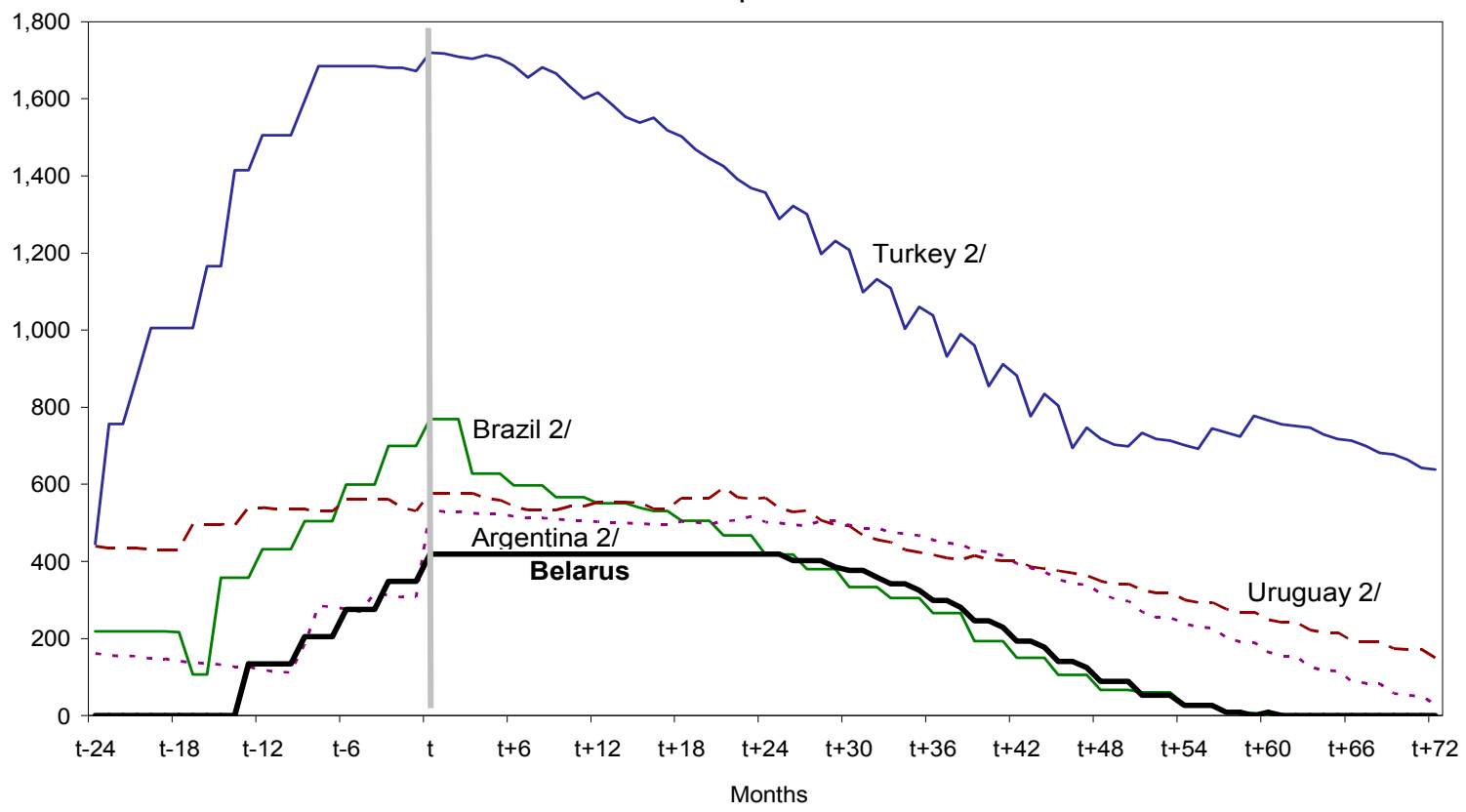

B. Approved and Forthcoming Exceptional Access Cases since September 2008

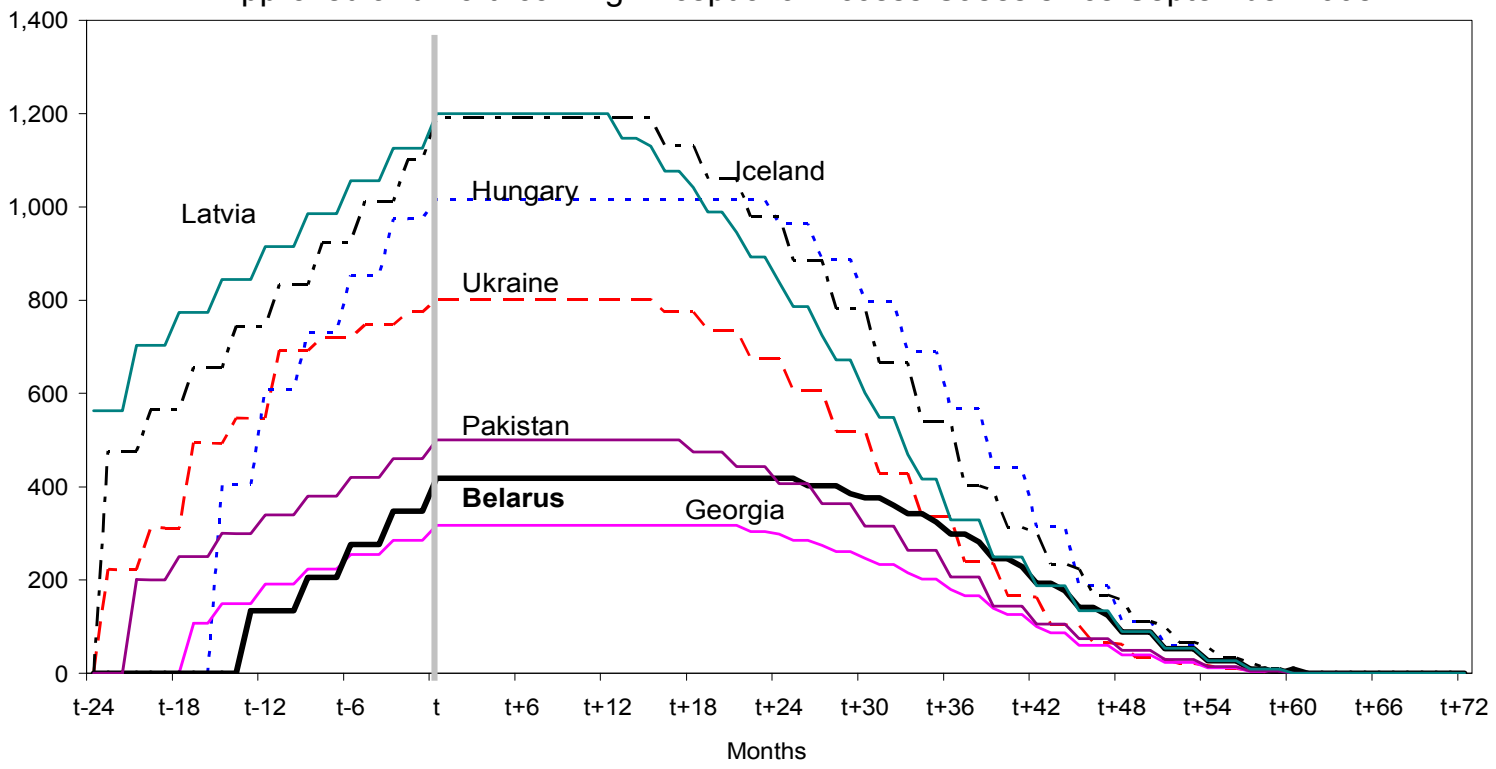

Source: IFS, Finance Department, and IMF staff estimates.

$1 /$ Peak borrowing is defined as the highest level of credit outstanding for a member, in percent of quota. Month $t$ represents the month of the highest historical credit outstanding (in percent of quota). For Argentina, $\mathrm{t}$ is September 2001; for Brazil, September 2003; for Turkey, April 2003; and for Uruguay, August 2004. For the countries in Panel B, $\mathrm{t}$ would be reached in February 2010 in the cases of Hungary, Georgia and Belarus, October 2010 in the cases of Iceland and Ukraine, and August 2010 in the case of Pakistan. For comparability, projected repurchases are assumed to be on an obligations basis.

2/ Projected repurchases (on an obligation basis) as of May 2005. Schedules do not show large early repurchases made by Argentina, Brazil, and Uruguay in 2005-06. 
Table 6. Belarus - Impact on GRA Finances

(In millions of SDRs, at end of period unless otherwise noted)

\begin{tabular}{|c|c|c|c|c|c|c|c|}
\hline & Jan-2009 & 2009 & 2010 & 2011 & 2012 & 2013 & 2014 \\
\hline \multicolumn{8}{|l|}{ Exposure } \\
\hline Fund GRA credit outstanding to Belarus 1/ & 517.8 & $1,343.0$ & $1,618.1$ & $1,618.1$ & $1,320.8$ & 546.1 & 34.4 \\
\hline Fund GRA credit outstanding to Belarus (percent of quota) 1/ & 134.0 & 347.6 & 418.8 & 418.8 & 341.8 & 141.3 & 8.9 \\
\hline Fund GRA credit outstanding to Belarus (percent of total GRA credit outstanding) 2/ & 2.9 & $\ldots$ & $\ldots$ & $\ldots$ & $\ldots$ & $\ldots$ & $\ldots$ \\
\hline Fund GRA credit outstanding to five largest debtors (percent of total GRA credit outstanding) 2 / & 85.6 & $\ldots$ & $\ldots$ & $\ldots$ & $\ldots$ & $\ldots$ & $\ldots$ \\
\hline \multicolumn{8}{|l|}{ Liquidity } \\
\hline One-year Forward Commitment Capacity (FCC) 3/ & $97,603.9$ & $\cdots$ & $\ldots$ & $\ldots$ & $\cdots$ & $\cdots$ & $\cdots$ \\
\hline Belarus's impact on FCC 4/ & $(1,618.1)$ & $\ldots$ & $\ldots$ & $\ldots$ & $\ldots$ & $\ldots$ & $\ldots$ \\
\hline \multicolumn{8}{|l|}{ Prudential measures } \\
\hline Fund GRA credit outstanding to Belarus (percent of current precautionary balances) 5/ & 7.5 & $\ldots$ & $\ldots$ & $\ldots$ & $\ldots$ & $\ldots$ & $\ldots$ \\
\hline \multicolumn{8}{|l|}{ Debt and Debt Service Ratios 6/ } \\
\hline Belarus's GRA credit outstanding (percent of total external debt) & 5.2 & 11.0 & 11.6 & 10.8 & 8.1 & 2.9 & 0.2 \\
\hline Belarus's GRA credit outstanding (percent of GDP) & 1.3 & 3.6 & 3.9 & 3.4 & 2.4 & 0.9 & 0.0 \\
\hline Belarus's GRA credit outstanding (percent of gross international reserves) & 27.4 & 39.2 & 30.5 & 23.8 & 16.0 & 5.5 & 0.3 \\
\hline Belarus's GRA debt service to the Fund (percent of exports of goods and services) & 0.0 & 0.1 & 0.2 & 0.2 & 1.0 & 2.1 & 1.2 \\
\hline Belarus's GRA debt service to the Fund (percent of total external debt service) & 0.2 & 2.2 & 4.0 & 3.5 & 18.1 & 29.1 & 18.0 \\
\hline \multicolumn{8}{|l|}{ Memorandum items } \\
\hline Fund's precautionary balances $5 /$ & $6,938.6$ & $\ldots$ & $\ldots$ & $\ldots$ & $\ldots$ & $\ldots$ & $\ldots$ \\
\hline Fund's residual burden sharing capacity $7 /$ & 40.0 & $\cdots$ & $\cdots$ & $\ldots$ & $\ldots$ & $\cdots$ & $\cdots$ \\
\hline Projected payment of charges to the Fund on GRA credit outstanding & 2.6 & 20.2 & 44.2 & 45.9 & 43.0 & 23.9 & 6.1 \\
\hline Projected debt service payments to the Fund on GRA credit outstanding & 2.6 & 20.2 & 44.2 & 45.9 & 340.4 & 798.6 & 517.9 \\
\hline
\end{tabular}

Sources: Belarus authorities, Finance Department, World Economic Outlook, and IMF staff estimates.

$1 /$ Repurchases follow the obligations schedule.

2/ Reflects total Fund credit outstanding as of end-December, 2008, plus the first purchases of Belarus.

3/ As of end-December, 2008. The Forward Commitment Capacity is a measure of the resources available for new financial commitments in the coming year, equal to usable resources plus repurchases oneyear forward minus the prudential balance.

$4 /$ A single country's negative impact on the FCC is defined as the country's sum of Fund credit and undrawn commitments minus repurchases one-year forward.
$5 /$ As of end-April 2008 .

6/ Staff projections for total external debt, GDP, gross international reserves, and exports of goods and services, as used in the staff report that requests the proposed SBA. For Jan 2009, projections

for total external debt, GDP, gross international reserves, and exports of goods and services are as of end-December 2008.

7/ Estimated based on end-December data. Burden-sharing capacity is calculated based on the floor for remuneration at 85 percent of the SDR interest rate. Residual burden-sharing capacity is equal to to the total burden-sharing capacity minus the portion being utilized to offset deferred charges and takes into account the loss in capacity due to nonpayment of burden sharing adjustments by members in arrears. 
6. The Fund's share of Belarus' external debt and debt service would increase significantly if all purchases under the SBA were fully made (see Table 6). Belarus' outstanding use of Fund resources would account for about 11 percent of Belarus' projected external debt by end-2009, and peak somewhat above that by end-2010. Belarus' projected debt service to the Fund would peak in 2013 at about SDR 800 million. Given the low public external debt, debt service to the Fund would stay below 20 percent of total external debt service in 2012 and reach about 30 percent in 2013. ${ }^{3}$ In terms of exports of goods and services, external debt service to the Fund would be about 1 percent in 2012 and 2 percent in 2013.

\section{B. Impact on the Fund's Liquidity Position and Risk Exposure}

7. The proposed arrangement would reduce Fund liquidity by less than $\mathbf{2}$ percent. Commitments under the proposed arrangement would reduce the one-year forward commitment capacity of SDR 97.6 billion as of end-December 2008 by SDR 1.618 billion (see Table 6). ${ }^{4}$

\section{Fund credit to Belarus as a share of total current Fund credit from the GRA} would increase to 2.9 percent with the first purchase. The share of the top five borrowers of total outstanding credit would decrease slightly to just below 86 percent (see Table 6). ${ }^{5}$

9. Were Belarus to accrue arrears on charges under the proposed arrangement, the Fund's burden sharing mechanism could be put under severe strain. ${ }^{6}$ Charges on the new GRA obligations will be about SDR 20 million over the next year or about 50 percent of the Fund's estimated residual burden-sharing capacity (see Table 6). However, the impact on

\footnotetext{
${ }^{3}$ Currency holdings resulting from scheduled purchases under the proposed SBA would be subject to levelbased surcharges of 100 basis points over the basic rate of charge (adjusted for burdensharing) on credit outstanding exceeding 200 percent of quota from May 2009 through July 2013, and surcharges of 200 basis points on credit outstanding exceeding 300 percent of quota from November 2009 to January 2013.

${ }^{4}$ The FCC is the principal measure of Fund liquidity. The (one-year) FCC indicates the amount GRA resources available for new financing over the next 12 months. Following the creation of the Short-term Liquidity Facility (SLF), the calculation of the FCC will exclude repurchases falling due under the SLF.

${ }^{5}$ Given the possibility of new financing operations, including some that will involve exceptional access, the concentration of the Fund's lending portfolio is likely to change in coming months.

${ }^{6}$ Under the burden-sharing mechanism, the financial consequences for the Fund that stem from the existence of overdue financial obligations are shared between creditors and debtors through a decrease in the rate of remuneration and an increase in the rate of charge, respectively. The mechanism is used to accumulate precautionary balances in the special contingent account (SCA-1) and to compensate the Fund for a loss in income when debtors do not pay charges. The Executive Board has set a floor for remuneration at 85 percent of the SDR interest rate. No corresponding ceiling applies to the rate of charge. The adjustment for the SCA-1 was suspended, effective November 1, 2006, by the Executive Board (Decision No. 13858-(07/1), adopted January 3, 2007).
} 
the Fund's burden sharing capacity of potential arrears from this arrangement would decline if the Fund's loan portfolio were to expand further.

10. Potential GRA exposure to Belarus would be moderate in relation to the Fund's current level of precautionary balances. After the first purchase, Fund credit to Belarus would be about 7.5 percent of the Fund's current level of precautionary balances (see Table 6), and this exposure would rise to about 23 percent of current precautionary balances if the proposed SBA were fully drawn.

\section{AsSESSMENT}

\section{Belarus' capacity to repay the Fund will mainly depend on a large current} account adjustment and significant economic reforms. The proposed access, and the substantial and front-loaded financing under the program aim to strengthen confidence in Belarus' ability to address the effects of external shocks and the present environment of global deleveraging, bolstering reserves and providing breathing room for implementation of necessary adjustment under the proposed program. However, significant access to capital markets is unlikely until further structural reforms enhance Belarus' attractiveness to foreign investors. It would therefore be paramount that macroeconomic stabilization be undertaken along with further economic liberalization and structural reforms.

\section{There are considerable financial risks associated with the proposed arrangement}

for Belarus. Although the arrangement is not large in terms of available Fund resources, and Belarus' external debt is low, debt service to the Fund will be a large share of Belarus' external obligations. Moreover, there are substantial downside risks to the baseline scenario. The authorities' ability to operate the new exchange rate arrangement, based on a peg to a currency basket, and to give the public confidence in it, is untested. Moreover, weaker external demand for Belarusian exports, combined with very limited access to international capital markets, could lead to the re-emergence of financing gaps.

13. These risks may adversely affect Belarus' capacity to repay the Fund. The proposed access is large in terms of the debt service burden it generates in a medium-term context of demanding external financing requirements, particularly if the large turn-around in the current account does not materialize as expected. In this regard, the authorities' commitment to firm implementation of the program, including adherence to the new exchange rate regime, prompt response to changes in underlying conditions, and continued political support to further liberalize the economy and implement structural reforms are key to mitigating these risks and safeguarding Fund resources. 


\section{Statement by the IMF Staff Representative on the Republic of Belarus January 12, 2009}

1. This statement provides information on developments since the staff report was issued. This information does not change the thrust of the staff appraisal.

2. All prior actions have been implemented. The staff report (Appendix III, Table 3) already indicated that two of the five prior actions had been observed. The remaining prior actions were implemented by January 6, 2009:

- On January 2, 2009 the National Bank of the Republic of Belarus (NBRB) announced that the national currency would be repegged to a basket of equally weighted currencies consisting of the U.S. dollar, the Russian ruble, and the euro, and managed within a +5 percent band around the central parity. Furthermore, the authorities have announced the central parity for the basket and the component exchange rates of the basket. The new exchange rate for the U.S. dollar against the Belarusian rubel implies a 20 percent devaluation of the rubel relative to its value on October 31, 2008.

- On January 3, 2009, with a view to abolishing the ceiling on lending rates for rubel loans, the President of the Republic of Belarus signed a Resolution (09-124/1878) eliminating the Regulations (09/524-199, dated May 1, 2007 and 09-520/20, dated February 14, 2008) that had established such ceilings.

- On January 6, 2009, to eliminate the possibility of further transfers to central and local government deposits in commercial banks, the Minister of Finance and the Governor of the NBRB jointly adopted an Amendment to Decision 447/D, Articles 2.2.1, 2.2.2, and 2.2.4 of November 28, 2006 that permitted such transfers to take place.

3. On the monetary policy front, the NBRB has raised all key interest rates by two percentage points during the week of January 5 :

- In the context of the devaluation on January 1, the NBRB announced an increase in the refinancing rate by 2 percentage points (to 14 percent) effective January 8 .

- The fixed Lombard rate of the NBRB was increased by 2 percentage points (to 22 percent) on January 5, implying also a similar increase in the rate applicable for uncollateralized loans ( 25 percent).

4. While there were some reports of public anger and uncertainty following the January 1 devaluation, monetary and reserves data so far do not show any serious loss of confidence in the currency or the banks:

- There has reportedly been a rush to purchase imported durable goods. This appears to be based on the public's anticipation that once goods already in stores are sold, new imports will be more expensive. 
- There have been withdrawals of rubel deposits from banks amounting to some $4 \frac{1}{4}$ percent of rubel deposits. While this could, in part, be related to the sudden increase in demand for imported goods in a climate of general uncertainty, rumors of further devaluation or currency redenomination have also been responsible for the pressures. This has also been reflected in a modest increase in foreign exchange deposits held by the public.

- Pressures on international reserves have generally remained contained - the level of gross international reserves, which stood at $\$ 3,061$ million on January 1, had declined only marginally to $\$ 3,025$ million on January 6 .

- The staff has remained in contact with the authorities, and has advised them to make foreign exchange and liquidity available to banks and currency exchanges, to be prepared to raise interest rates further should pressures persist, and to ensure that they pursue a clear and consistent communication strategy. 
Press Release No. 09/05

International Monetary Fund

FOR IMMEDIATE RELEASE

Washington, D.C. 20431 USA

January 12, 2009

\section{IMF Executive Board Approves US\$2.46 Billion Stand-By Arrangement for Belarus}

The Executive Board of the International Monetary Fund (IMF) today approved a 15-month SDR 1.62 billion (about US\$2.46 billion) Stand-By Arrangement for Belarus in support of the country's efforts to adjust to external shocks. The approval makes an amount equivalent to SDR 517.8 million (about US\$787.9 million) available immediately. The remainder will be phased thereafter, subject to quarterly reviews. The Stand-By Arrangement entails exceptional access to IMF resources, amounting to 418.8 percent of Belarus's quota.

The main objectives of the IMF-supported program are to facilitate an orderly adjustment to external shocks and to address pressing vulnerabilities. To this end, the program contains strong macroeconomic adjustment measures and addresses a number of structural issues that are critical to the adjustment and mitigation of vulnerabilities.

Following the Executive Board discussion on Belarus, Mr. Takatoshi Kato, Deputy Managing Director and Acting Chairman, said:

"Belarus is experiencing serious economic problems. External vulnerabilities have been exposed by adverse terms of trade movements, falling demand from trading partners, and difficulties in securing external finance, leading to a decline in international reserves. In the face of these shocks and the adjustment needed to contain them, the economy is likely to slow in 2009.

"The authorities have a clear strategy to address the challenges they face. They have already adjusted the exchange rate and put in place tight fiscal and wage policies. The measures already taken and announced are strong and, with resolute implementation, will be sufficient to restore stability. Together with planned structural reforms in key areas, these measures should help return the economy to a higher growth path by 2010-11.

"The adjustment of the exchange rate parity will help restore competitiveness and address external imbalances. The adoption of the new currency basket and wider band will leave the 
economy better able to adapt to external shocks, thus making it less likely that further exchange rate adjustment will be needed. The increase in interest rates that preceded the shift in the exchange rate regime, and their subsequent further upward adjustment, will help support the new exchange rate regime.

"Fiscal tightening will help to bring demand into line with external financing constraints. Key measures include the planned reduction in directed lending, observance of the target of a balanced central government budget balance, and maintenance of a prudent wage policy in the broader public sector. The authorities also plan to review the social safety net, in cooperation with the World Bank, to ensure that the most vulnerable groups are protected against the economic downturn and the effects of utility tariff increases.

"Key structural reforms, including price and wage liberalization, should follow the realignment of the currency. Broader measures to support private sector developmentincluding reductions in the size of government, deregulation, and privatization - are also needed to underpin better medium-term growth, and should be undertaken as fast as market conditions allow.

"Structural reform in the financial sector is an important priority in the program. The authorities have already enacted a blanket deposit guarantee, but the framework for financial sector liquidity and solvency support still needs to be refined. It will also be crucial to purge the banking system of directed lending. Doing so will improve incentives for banks and their borrowers to manage risks, and strengthen banks' capital positions.

"The authorities have developed a strong macroeconomic program to address the challenges Belarus is facing. Their actions merit the substantial financial support that the Fund will provide. The strength of the macroeconomic program gives confidence that Belarus will make a speedy return to stability. If the authorities follow through on their plans for reforms in key structural areas, prospects are also good for a resumption of rapid growth," Mr. Kato said.

\section{Recent Economic Developments}

Belarus's economic growth has been impressive in the last few years. It has averaged close to 9 percent since 2002, with spare capacity and high investment underpinning production growth, as well as a combination of sharp export price gains, strong growth in trading partners, and large energy subsidies from Russia supporting demand. However, recently the economy has been overheating. Since bottoming in 2006 at 7 percent, inflation has been rising in line with developments in other countries in the region and currently stands at 16 percent. The rise in inflation is partly the result of global food and energy shocks, but indicators of domestic demand, high credit growth, and output growth above trend point to an overheated economy. 
During the boom, external vulnerabilities were not addressed: international reserves remained low, some Russian energy prices were unwound, and exports to Western markets remained concentrated on oil products, while higher value-added exports were mostly to the Commonwealth of Independent States (CIS). And in the financial sector, credit risks from foreign exchange borrowing and funding exposure to the global banking system have grown. Recent global developments have exposed these vulnerabilities, and as result, the currency peg to the U.S. dollar came under pressure toward the end of 2008.

\section{Program Summary}

Belarus's economic program is designed to facilitate adjustment to external shocks and reduce the vulnerabilities, and also includes a number of structural reforms on issues that are critical to the mitigation of vulnerabilities. A sharp economic slowdown is forecast for 2009, with GDP projected to grow at 1-2 percent, after reaching 10.5 percent in 2008. Inflation is projected to slow to 11.5 percent in 2009 .

Key features of the program are:

- The implementation of a new exchange rate regime. The dollar peg has served the economy well, but the recent volatility of dollar-euro and dollar-ruble rates created significant problems: hindering inflation control on the dollar downside early in 2008, and creating competitiveness issues on the recent upside. The program includes a devaluation to a new dollar parity, with a simultaneous switch to a currency basket that better reflects the structure of Belarus's trade and financial flows, both measures implemented on January 1, 2009.

- A tight fiscal stance to contain domestic demand growth. Fiscal tightening measures are aimed directly at slowing investment and consumption. Wage growth will slow in the budget and state enterprise sectors in 2009, and public investment will be restrained. Selected subsidies will be curtailed, but the social safety net will be strengthened to protect the most vulnerable people.

- On structural policies, the program places economic liberalization as a priority, particularly price liberalization. The program also envisages efforts to enhance the role of the private sector by reducing the distortion of taxes and the regulatory burden on private companies, and continuing privatization efforts.

Belarus joined the IMF on July 10, 1992; its quota is SDR 386.4 million (about US\$588.0 million), Its latest arrangement with the IMF was a Stand-By Arrangement that expired on September 11, 1996. 
Belarus: Selected Economic Indicators, 2005-10 1/

\begin{tabular}{|c|c|c|c|c|c|c|}
\hline & 2005 & 2006 & 2007 & 2008 & 2009 & 2010 \\
\hline & \multicolumn{6}{|c|}{ (Annual percentage change, unless otherwise specified) } \\
\hline \multicolumn{7}{|l|}{ National accounts and employment } \\
\hline Real GDP & 9.4 & 10.0 & 8.2 & 10.5 & 1.4 & 2.3 \\
\hline Total domestic demand & 11.0 & 13.9 & 12.8 & 14.3 & -2.2 & 1.3 \\
\hline Consumption & 10.1 & 9.0 & 9.7 & 10.7 & -0.7 & 1.4 \\
\hline Private & 15.0 & 13.0 & 13.3 & 14.0 & -1.0 & 1.5 \\
\hline Public & 0.4 & -0.2 & 0.5 & 1.2 & 0.0 & 1.0 \\
\hline Investment & 13.3 & 26.2 & 19.5 & 21.4 & -4.9 & 1.0 \\
\hline Of which: fixed & 19.5 & 26.5 & 19.7 & 20.8 & -5.0 & 1.0 \\
\hline Net exports 2/ & 0.1 & -7.9 & -0.8 & -6.9 & 3.9 & 0.9 \\
\hline \multicolumn{7}{|l|}{ Consumer prices } \\
\hline End of period & 7.9 & 6.6 & 12.1 & 13.7 & 11.5 & 8.0 \\
\hline Average & 10.3 & 7.0 & 8.4 & 14.9 & 15.7 & 6.1 \\
\hline & \multicolumn{6}{|c|}{ (In percent of GDP) } \\
\hline \multicolumn{7}{|l|}{ External Debt and Balance of Payments } \\
\hline Current account & 1.4 & -3.9 & -6.8 & -7.6 & -5.4 & -3.6 \\
\hline Trade balance & -1.7 & -6.1 & -9.1 & -9.6 & -8.6 & -7.4 \\
\hline Exports of goods & 53.3 & 53.7 & 54.3 & 57.2 & 52.5 & 54.1 \\
\hline Imports of goods & -55.0 & -59.8 & -63.4 & -66.8 & -61.2 & -61.5 \\
\hline Gross external debt & 17.0 & 18.5 & 28.0 & 25.3 & 32.4 & 33.9 \\
\hline Public 3/ & 2.6 & 2.3 & 6.6 & 5.9 & 11.8 & 13.1 \\
\hline Private (banks and state-owned enterprises) & 14.4 & 16.3 & 21.5 & 19.4 & 20.6 & 20.8 \\
\hline \multicolumn{7}{|l|}{ Savings and investment } \\
\hline Gross domestic investment & 28.5 & 32.2 & 33.2 & 36.2 & 32.9 & 32.8 \\
\hline Public & 9.4 & 9.6 & 8.6 & 11.2 & 8.0 & 9.5 \\
\hline Private & 19.1 & 22.6 & 24.6 & 25.1 & 24.9 & 23.3 \\
\hline National saving & 29.9 & 28.3 & 26.4 & 28.7 & 27.4 & 29.2 \\
\hline Public & -0.7 & 1.4 & 0.4 & -0.5 & 0.3 & -0.7 \\
\hline Private & 30.6 & 26.8 & 25.9 & 29.1 & 27.2 & 29.9 \\
\hline \multicolumn{7}{|l|}{ Public sector finance } \\
\hline Central government balance & -1.7 & 0.4 & -0.6 & -0.8 & 0.0 & -1.0 \\
\hline General government balance & -0.7 & 1.4 & 0.4 & -0.5 & 0.3 & -0.7 \\
\hline Revenue & 47.4 & 49.1 & 50.0 & 52.2 & 48.9 & 48.5 \\
\hline Expenditure & 48.0 & 47.6 & 49.6 & 52.7 & 48.6 & 49.2 \\
\hline \multicolumn{7}{|l|}{ Of which } \\
\hline Wages & 8.1 & 8.2 & 8.0 & 6.9 & 6.4 & 6.4 \\
\hline Subsidies and transfers & 9.0 & 9.0 & 10.6 & 10.6 & 9.6 & 8.8 \\
\hline Investment & 9.4 & 9.6 & 8.6 & 11.2 & 8.0 & 9.5 \\
\hline & \multicolumn{6}{|c|}{ (Annual percentage change unless indicated otherwise) } \\
\hline Terms of Trade & 12.3 & 3.9 & -2.5 & 8.7 & -3.5 & 1.6 \\
\hline Real Effective Exchange Rate & -0.1 & -2.0 & -4.4 & -1.1 & -4.8 & -3.5 \\
\hline Official reserves (millions of U.S. dollars) & 1,297 & 1,383 & 4,182 & 2,865 & 5,204 & 8,085 \\
\hline Official reserves (months of imports of goods and services) & 0.9 & 0.7 & 1.6 & 0.8 & 1.7 & 2.3 \\
\hline Official reserves (percent of short-term debt) & 39.3 & 31.6 & 56.8 & 33.5 & 62.2 & 91.5 \\
\hline
\end{tabular}

Sources: Belarusian authorities; and IMF staff estimates.

$1 /$ Assumes exchange rate re-peg to a basket of currencies within a horizontal band, the upfront adoption of policies to reduce domestic demand.

2/ Contribution to growth.

3/ Gross consolidated debt of the public sector (general government, central bank, and guarantees extended to non-financial public enterprises). 


\section{Statement by Willy Kiekens, Executive Director for the Republic of Belarus and Johann Prader, Alternate Executive Director January 12, 2009}

The Belarus authorities thank Management and the staff for the constructive discussions and for supporting their request for a Stand-By Arrangement. All policy measures critical for stabilizing the economy and for addressing a number of structural problems were formulated as prior actions and have already been implemented. The authorities are committed to pursuing the policies as outlined in their Letter of Intent and to adjusting the policies as needed, in consultation with the staff, in order to achieve the program objectives.

The authorities are proud of Belarus' economic performance during the last five years. In this period, GDP rose by 60 percent in real terms. This is one of the best performances in the CIS countries, which was characterized by a high level of investment and reducing energy intensity combined with strong improvements in labor productivity. This justified the significant increases in wage levels. At the same time, the authorities were able to manage the economy prudently. At the end of 2008, the gross general government debt was 6 percent of GDP, down from 11.6 percent in 2007, while external debt stood at 25.3 percent of GDP, down from 28 percent in 2007. Moreover, the overall public balance sheet of Belarus is strong because, as the staff rightly points out, the various public enterprises have substantial value.

However, the authorities recognize that the economy faces huge vulnerabilities because of the global financial and economic crisis and the limited capacity to cover the significant balance of payment needs. The Staff Report documents well the nature and sources of these vulnerabilities.

In August 2007, during the last Article IV consultation, the staff and the Board had recognized that the peg of the rubel to the US dollar had served Belarus well and that there was no need for an adjustment of the nominal exchange rate.

Indeed, a year later, circumstances have changed. In Box 1 of their Report, the staff has assessed that the real effective exchange rate is now - most likely - overvalued in the order of 11 to 20 percent. The authorities agree that preserving and restoring external competitiveness is critical for addressing Belarus' balance of payments need. They also agree that the most significant part of their strategy should be policy adjustment rather than financing. However, determining the size of the necessary exchange rate adjustment has been a particularly complex and difficult part of the program negotiations.

The staff has calculated that, under the macroeconomic balance approach, the REER is above equilibrium by about 11 to 14 percent. A similar conclusion follows from the external sustainability approach. If one assumes an appropriate but still prudent negative net foreign asset position of 40 percent of GDP, the currency is deemed to be 13 percent overvalued. Lastly, the wage-based model shows an overvaluation of around 11 percent, if dollar wages would reach US\$ 570 per month, as originally announced by the President. 
The authorities agree that the exchange rate regime needs to be made more flexible. This was also advised by a number of Directors during the last Article IV Consultation discussion. Hence, since early January 2009, the currency is no longer pegged solely to the US dollar but to a basket of currencies, i.e. the US dollar, the euro and the Russian ruble, with each currency having a one third weight. Moreover, the fluctuation band on both sides of the central parity has been widened to 5 percent. This creates more room to absorb shocks through moderate exchange rate adjustments.

The authorities also agree to the need for some moderate step adjustment in the nominal parity rate. Indeed, staff calculations point to only a limited overvaluation. Because of the very open nature of the Belarusian economy, any significant devaluation would result in a significant rise in he price of imported inputs that affect the cost of exports, which Belarus is unlikely to reflect fully in its export prices, given the prevailing conditions in world markets. Moreover, any significant devaluation will also considerably complicate the maintenance of low inflation, thereby drastically eroding the initial competitiveness gain of the exchange rate measure.

The authorities accept that for Belarus wage constraint is far more effective to preserve external competitiveness than a nominal exchange rate devaluation. Hence, the authorities have reversed most of the already announced public sector wage increases of October 2008 and have decided to limit them to 5 percent. This was a very bold measure, which largely preserves the equilibrium wage level as shown in Box 1 of the Staff Report. The measure also invalidates staff conclusions about the REER under the wage-based model, as it assumes the full implementation of the wage increase to US\$ 570. In Belarus, wages in state-owned enterprises and in the private sector largely follow increases in public sector wages.

Although initially, the authorities strongly preferred to limit the devaluation to 10 percent, they have now agreed with the staff's condition of a 20 percent devaluation, implemented on January 1, 2009. This was done simultaneously with the introduction of the currency basket.

It was a difficult judgment to balance the desire to limit the devaluation to what seemed necessary for preserving competitiveness with the need to avoid the perception of depositors that too small a devaluation would be followed by subsequent devaluations, thereby triggering a conversion of rubel deposits into foreign currency. Developments in the exchange rate in neighboring countries and the need for rather significant exchange market interventions in November and December were factors that tilted the balance toward a bolder exchange rate adjustment of 20 percent.

The wage decision, and to a lesser extent, the exchange rate adjustment, are critical measures for limiting the trade deficit. Continued strict fiscal, monetary and credit policies will be equally necessary to limit the balance of payments deficit and preserve the confidence of depositors in the currency.

The central government budget for 2009 aims at a balanced outcome and discontinuation of directed leading through banks. This implies a reduction of overall state funding by 3 percent of GDP, as compared to the funding in 2008. Paragraph 13 of the Memorandum of Economic 
and Financial Policies details the most important measures that should help reach this fiscal target. It is worth noting that under the baseline scenario of the public debt sustainability analysis (Table I.2 on page 48 of the Staff Report), public sector debt is projected to drop to 4.1 percent of GDP this year before reaching only 1 percent of GDP in 2012.

Monetary policy will target an inflation of about 11 percent by end 2009. Tight monetary policy will imply positive interest rates that will be transmitted to the real economy by abolishing interest rate ceiling on loans by banks to the corporate sector. Finally, the central bank policy rates will also be set to ensure the build-up of international reserves. Consistent with this stance, the central bank raised its key interest rates in early January following the adjustment of the exchange rate.

Tight macroeconomic policies and the exchange rate measure are projected to result in a correction of the current account, compared with the baseline, of US $\$ 4.3$ billion or about 7.5 percent of GDP. A major part of this correction results from very tight wage, fiscal and credit policies. The remaining financing gap in 2009 is scheduled to be filled by a possible loan from Russia in an amount of US\$ 1 billion or 1.75 percent of GDP, and by drawing on the Fund in an amount of US\$ 2.1 billion or 3.6 percent of GDP.

Belarus' program is not limited to what are indeed many bold measures of aggregate domestic demand constraints. The program also includes significant structural reforms.

One important set of structural measures relates to the financial sector. As mentioned above, interest ceilings for bank credit to the corporate sector have been abolished, as are directed credits, except for credits by the central bank to the non-financial sector which will be discontinued beginning in 2010. Both central and local governments will no longer maintain deposits with commercial banks. Other important measures relate to the process of privatizing the large state-owned banks, as detailed in paragraph 11 of the Memorandum of Economic and Financial Policies.

Other reforms will improve the business climate and governance of the economy. Price controls were reduced last year. Regulation limiting monthly price increases to no more than 0.5 percent will not be extended beyond March 2009. In 2010, mandatory wage policy in companies where the government has a majority control will be discontinued. More generally, the government is in the process of implementing a comprehensive plan for both creating a favorable investment and business climate and putting in place mechanisms and instruments needed for the private sector to develop. In particular, the government will create an attractive environment for foreign investment. In this vein, the turnover tax will be halved in 2009 and the local sales tax and the effective personal income tax rate reduced. The privatization of companies and banks will be accelerated. More generally, the state will reduce its control and influence over productive enterprises, while improving governance and legal structures that create a level playing field for economic agents.

To make progress with these and other structural reforms, the government is seeking closer cooperation with and lending from the World Bank and the EBRD. The government is also implementing agreed measures that are facilitating closer cooperation with the European Union. As mentioned in the Staff Report, after the expiration of this Stand-By Arrangement, 
the government will consider requesting, in early 2010, a successor IMF arrangement, possibly an Extended Fund Facility (EFF), to further advance the transition towards a wellfunctioning market economy and improve access to international capital. 